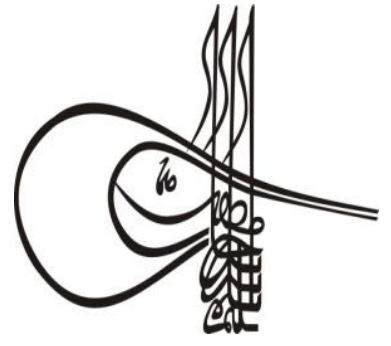

Received/Geliş: 19.08.2019

Go Report Dates/Rapor Tarihleri: Referee 1 (28.09.2019)-Referee 2 (28.09.2019)

This article was checked by intihal.net.

\author{
Turkists Stuties \\ Historical Analysis \\ Volume 14 Issue 3, 2019, p. 669-733 \\ DOI: 10.29228/TurkishStudies.30269 \\ ISSN: 2667-5552 \\ Skopje/MACEDONIA-Ankara/TURKEY
}

Research Article / Araştırma Makalesi
Article Info/Makale Bilgisi

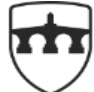

INTERNATIONAL BALKAN UNIVERSITY

EXCELLENCE FOR THE FUTURE IBU.EDU.MK

VAccepted/Kabul: 30.09 .2019

\title{
KORAMAZ VADİSİ COLUMBARIUM MEZARLARI
}

\author{
Bilgin YAZLIK
}

\begin{abstract}
öz
Kayseri, Anadolu'nun merkez noktası sayılacak bir konumda, Erciyes Dağı eteklerinde kurulu önemli bir şehirdir. Kayseri, Kültepe'den günümüze kadar her dönemde önemli ticaret yollarının kavşak noktası olmuştur. Kayseri, Roma Dönemi'nde de cazibesini korumuş ve önemli bir merkez haline gelmiştir. Roma'dan günümüze kadar ulaşan anit mezarlar, sur kalıntıları ve tapınak kalıntıları Roma'nın Kayseri'de gerçekleştirdiği imar hareketinin önemini göstermektedir. Kremasyon, Roma'da kabul görmüş önemli bir defin geleneğidir. Bu gelenek bir dönem columbarium mezar adı ile bilinen toplu mezarlar kullanılarak yaygınlaşmıştır. Columbarium mezarlar, belirli bir halk sınıfına hizmet veren toplu defin alanlarıdır. Koramaz Vadisi, Kayseri şehir merkezinin yaklaşık yirmi kilometre kuzey doğusunda yer alan, içerisinde çok sayıda kaya mezar, kaya kilise ve yaşam devam eden köyler barındıran on iki kilometre uzunluğa sahip bir deprem kırığı oluşumudur. Bu çalışma kapsaminda Koramaz Vadisi'nde bulunan yirmi bir adet columbarium mezar ve üç adet de güvercinlik incelenmiştir. Çalışmanın ilk kısmında Kayseri'nin genel tarihi anlatılmakta ardindan Koramaz Vadisi'nden bahsedilmektedir. Daha sonra Roma Dönemi cenaze defin yöntemleri incelenmekte, özellikle kremasyon defin ve columbarium mezarları ele alınmaktadır. Güvercinlikler ile columbarium mezarlar sıkça karıştırılmaktadır, columbarium mezarların neredeyse tamamının sonradan güvercinliğe dönüştürülmüş olmaları bunda önemli bir etkendir. Dolayısı ile sonuç kısmında çalışmaya konu olan Koramaz Vadisi columbarium mezarları detaylı olarak incelenmekte, güvercinlikler ile farkları ortaya açıkça konulmaktadır.
\end{abstract}

Anahtar Kelimeler: Columbarium, Columbarium Mezar, Güvercinlik, Kremasyon, Koramaz. 
COLUMBARIM TOMBS OF KORAMAZ VALLEY

\begin{abstract}
Kayseri is an important city located at the foot of Mount Erciyes, which is considered to be the center point of Anatolia. Kayseri has been the crossroads of important trade routes in all periods from Kültepe to the present day. Kayseri, has retained its charm during the Roman period and has become an important center. The monumental tombs, city walls and temple ruins dating from Rome to the present day show the importance of the Roman architectural movement in Kayseri. Cremation is an important burial tradition accepted in Rome. This tradition was popularized by mass tombs known as columbarium tombs. Columbarium tombs are mass burial sites that serve a particular public group. Koramaz Valley is a twelve kilometers long earthquake fracture which is located about twenty kilometers to the north east of Kayseri city center and contains many rock tombs, cave churches and villages in which life continues. Twenty-one columbarium tombs and three dovecotes in Koramaz Valley were investigated. In the first part of the study, general history of Kayseri is explained and then Koramaz Valley is mentioned. Later, Roman funeral burial methods are examined, especially cremation burials and columbarium tombs are discussed. Dovecotes and columbarium tombs are often confused, with the fact that almost all of the columbarium tombs were later converted into dovecotes. Consequently, the columbarium tombs of the Koramaz Valley, which are the subject of the study, are examined in detail and the differences between the columbarium tombs and the dovecotes are clearly revealed.
\end{abstract}

\title{
STRUCTURED ABSTRACT
}

The first settlement known in Kayseri is located on the Kültepe mound (Kulakoğlu, 2010). It is known to be founded by Kanesh. Today it is an important archaeological excavation area and it is located $3 \mathrm{~km}$ west of Koramaz Valley which is the subject of this work. Following Kanesh; Hittite, Phrygian, Persian, Cappadocia Kingdom, Roman, Byzantine, Danishmend, Mongols, Seljuk and Ottoman domination and Republic of Turkey was continuing with the aforementioned sequence in Kayseri (Erkiletlioğlu, 1993). Kayseri is a very big and important city with a population of four hundred thousand before the Roman period. City, M.S. 17 became a province of Rome and Roman rule continued until 395. After the division of Rome into east and west, Kayseri came under Byzantine (Eastern Roman) rule. Kayseri has been a very important and sacred city for Rome especially due to the existence of Mount Erciyes. Kayseri's present name was designated Caesarea (pronounced Kaisaria), referring to the famous emperor Julius Caesar during the Roman period. Today, there are tumulus tombs, fountains, temples and castle fortifications from the Roman period in Kayseri. In the last period of Rome, which has pagan beliefs, Christianity raids occurred and Kayseri was affected by these raids. When Rome was divided, Kayseri became a very important center for Christianity. It is also known that Basileius and Gregorius lived in Kayseri during these dates (Erkiletlioğlu, 2018). During the Roman period, many temples such as Zeus Poliouchos Temple, Apollo Potros 
Temple, Tyche Temple, Serapis Temple, Argios Temple were built in Kayseri (Erkiletlioğlu, 1993). Today some ruins thought to belong to these Roman temples can be seen around Koramaz Valley.

Koramaz Valley is an earthquake fracture with a length of approximately $12 \mathrm{~km}$ which is located within the borders of Melikgazi district of Kayseri. The name Koramaz appears in the Ottoman Archives (devletarsivleri.gov.tr, 2019) for the first time in the documents. It is known that the name Koramaz belongs to a sub-administrative unit of the period, that the Koramaz sub-district is attached to Kayseri sanjak and that it has villages attached to it. At the beginning of the 16th century, there are 34 villages connected to Koramaz Sub-district. The mountain, which is 1.900 meters high, is located to the east of Koramaz Valley and is named Koramaz Mountain. Within the Koramaz Valley, from east to west; Büyük Bürüngüz (Ulu Bürüngüz), Subaş1 (Üsgübü), Küçük Bürüngüz (Kiçi Bürüngüz), Ağırnas, Turan (Dimitre), Vekse, Bağpınar (Isbidin) villages are located and life continues. Koramaz Valley attracts attention not only with its historical wealth but also with its natural wealth. The scenic hiking trails in the valley (Kayseri Yürüyüş Rotaları ve Turizm Keşif Rehberi, 2014) have recently received increasing attention.

It is seen that inhumation and cremation were applied together in the early periods in Rome. Roman twelve tablet laws prohibited the burial of the dead into the city. The major reason for this is the prevention of epidemics that can be transmitted from the dead body to healthy bodies. For this reason, cemeteries were built out of the city during the Roman period (Civelek, 2007). In the cremation burial tradition, the dead body was put on ceremony and burned on a pile of rectangular wood with trappings. The entire body was nonflammable and about $2.5-4 \mathrm{~kg}$ of noncombustible bones remained, the remaining ash was collected and filled into terracotta vessels called urne or ostothek.

Due to increasing burial costs and capacity, Roman society began to use the method of preserving urns in mass grave niches carved underground or in rock during the Augustan period. The structures built for this purpose are called columbarium tomb. This new tradition was adopted by modern organizations that manage community and funeral expenses and developed funeral insurance-derived functions in which the deceased would be dignified and buried alone in a tomb with a beautiful ceremony (Borbonus, 2014).

The word columba means Latin pigeon, while the columbarium was used as a dovecote in Roman times. Columbaria is the plural of the word columbarium. The word columbarium is actually the name given to each niche within the tomb of the columbarium (Gilli, 2017). The reason why Romans call these monumental mass graves as dovecote is undoubtedly the fact that the structures are quite similar to dovecotes. Even today, it is very difficult and technical to distinguish between a dovecote and a columbarium tomb, which is clearly evidence of why the Romans used the name. This, in other words, the fact that columbariums have been used for many years as a dovecote, and that the first function is not known by the public, has caused the columbariums to have suffered relatively less treasure destruction until today.

To avoid confusion of dovecotes and columbariums, the term columbarium tomb is used (Borbonus, 2014). Columbarium tombs are 
not only visually unique, but also the first known mass graves of Rome to provide mass burial services to biological families and residents of the same house (Borbonus, 2014).

The first detection of columbarium tombs in Koramaz Valley was made by Eric Gilli. However, Gilli's work is merely a preliminary fixation and contains general statements. When the rock carved structures in the Koramaz Valley are examined as a whole, it is seen that the structures change function continuously. For example, a rock tomb built as a rock tomb during the Roman period turned into a cave church, or a structure used as a columbarium tomb after the loss of its function naturally used as a dovecote (Picture 25). In another scenario, the columbarium tomb was later transformed into a place for must production (Figure 36). There are studies in the literature where structures in the region are considered as dovecote (Karakaya, 2014).

Columbarium tombs, although the first purpose of the mass burial area in time with the Roman invasion of Christianity in Rome, the cremation tradition was abandoned, the buildings remained dysfunctional, the chimneys opened to the ceilings and continued to use these modifications as a dovecote.

In this work, a total of 21 columbarium tombs in the Koramaz Valley were identified and analyzed. Columbarium tombs are known to have been converted into dovecotes over time and are often confused with dovecotes. In this work, the differences between dovecotes and columbarium tombs were clearly revealed and Koramaz Valley columbarium tombs were introduced. It is predicted that columbarium tombs can be found both in different parts of Koramaz Valley and in different valleys in Kayseri.

Detailed and advanced research and archaeological excavations in the region will provide more detailed information about the history of the columbarium tombs mentioned in this work. With the help of archaeological materials such as urne and ash remains to be found in the columbarium tombs, the claims in this work can be confirmed and exact dating will be possible.

Keywords: Columbarium, Columbarium Tomb, Dovecote, Cremation, Koramaz.

\section{Kayseri Tarihi}

Kayseri’de bilinen ilk yerleşimlerden biri de Kültepe'dir ve kazılarda Eski Tunç Çağı'nın erken dönemlerine kadar inilmiştir (Kulakoğlu, 2010). Kültepe höyüğü bugün önemli bir arkeolojik kazı alanıdır ve bu çalışmaya da konu olan Koramaz Vadisi'nin $3 \mathrm{~km}$ batısında yer almaktadır. Kaneş’i takiben Kayseri’de Hitit, Frig, Pers, Kapadokya Krallığı, Roma, Bizans, Danişmend, Moğol, Selçuklu, Osmanlı ve Türkiye Cumhuriyeti Devleti egemenliği anılan sıra ile süregelmiştir (Erkiletlioğlu, 1993). Kayseri, Roma egemenliğinden önce 400 bin nüfusa sahip oldukça büyük ve önemli bir şehirdir. Şehir, M.S. 17 tarihinde Roma'nın bir ili haline gelmiştir ve Roma egemenliği 395 yılına kadar devam etmiştir. Roma’nın doğu ve batı olarak ikiye bölünmesinin ardından Kayseri, Bizans (Doğu Roma) yönetimi altına girmiştir. Kayseri, özellikle Erciyes Dağı'nın varlığı nedeni ile Roma için oldukça önemli ve kutsal bir şehir olmuştur. Kayseri’nin bugünkü adı Roma yönetimi döneminde ünlü imparator Julius Caesar'a atfen Caesarea (okunuşu Kaisaria) olarak belirlenmiştir. Kayseri'de bugün Roma 
Dönemi'nden kalma tümülüs mezarlar, çeşmeler, tapınaklar, kale sur duvarları kalıntıları bulunmaktadır. Pagan inanışa sahip olan Roma'nın son dönemlerinde Hristiyanlık akınları oluşmuş ve bu akınlardan Kayseri de etkilenmiştir. Roma'nın bölündüğü tarihte Kayseri Hristiyanlık için çok önemli bir merkez haline gelmiştir. Bu tarihlerde Basileius ve Gregorius'un Kayseri'de ikamet ettiği de bilinmektedir (Erkiletlioğlu, 2018). Roma Dönemi'nde Kayseri'de Zeus Poliouchos Tapınağı, Apollon Potros Tapınağı, Tyche Tapınağı, Serapis Tapınağı, Argios Tapınă̆ gibi çok sayıda tapınak inşa edilmiştir (Erkiletlioğlu, 1993), bugün bu Roma tapınaklarına ait olduğu düşünülen bazı kalıntılar Koramaz Vadisi civarında yer yer görülebilmektedir.

\section{Koramaz Vadisi}

Koramaz Vadisi, Kayseri ili Melikgazi ilçesi sınırları içerisinde yer alan yaklaşık $12 \mathrm{~km}$ uzunluğa sahip bir deprem kırı̆̆ı oluşumudur. Koramaz adı belgelerde ilk defa karşımıza Osmanlı Devlet Arşivlerinde (devletarsivleri.gov.tr, 2019) çıkmaktadır, Koramaz adının dönemin alt yönetim birimlerinden biri olan bir nahiyeye ait olduğu, Koramaz nahiyesinin Kayseri sancağına bağlı olduğu ve kendisine bağlı karyelerinin (köylerinin) olduğu bilinmektedir. 16. yüzyıl başlarında Koramaz Nahiyesine bağlı 34 köy bulunmaktadır (altı çizili olanlar bugün Koramaz Vadisi içerisinde yer almaktadır): Ulu Bürüngüz, Gergeme, Bâlâ Gesi, Merse, Vâniye, İspile, Mancusun, Kamber, Barsama, Salkuma, Tölös, Efkere, Nize, Darsıyak, Sarımsakl1, Dimitre, Germir, Tavlusun, Cirlavuk, Vekse, Gesi, Üskübi, Kiçi Bürüngüz, Ağırnas, Sultanhanı, Palas, Selasire, Kala-i Hıristo, Kırıf, Kozla, Giryat, Sağarak, Şavalak, Canbaz (Cömert, 2008). Koramaz Vadisi'nin doğusunda yer alan 1.900 metre yüksekliğe sahip dağın adı da Koramaz Dağı'dır. Koramaz Vadisi'nin içerisinde bugün doğudan batıya doğru; Büyük Bürüngüz (Ulu Bürüngüz), Subaşı (Üsgübü), Küçük Bürüngüz (Kiçi Bürüngüz), Ağırnas, Turan (Dimitre), Vekse, Bağpınar (Isbıdın) köyleri yer almakta ve yaşam süregelmektedir. Koramaz Vadisi sadece tarihi zenginliği ile değil aynı zamanda doğal zenginliği ile de dikkat çekmektedir. Vadi içerisinde yer alan doğal yürüyüş parkurları (Kayseri Yürüyüş Rotaları ve Turizm Keşif Rehberi, 2014) son zamanlarda artan bir ilgi görmektedir. Resim 1'de Koramaz Vadisi ana hattı ve vadi içerisinde yaşam devam eden 7 mahalle (köy) gösterilmektedir.

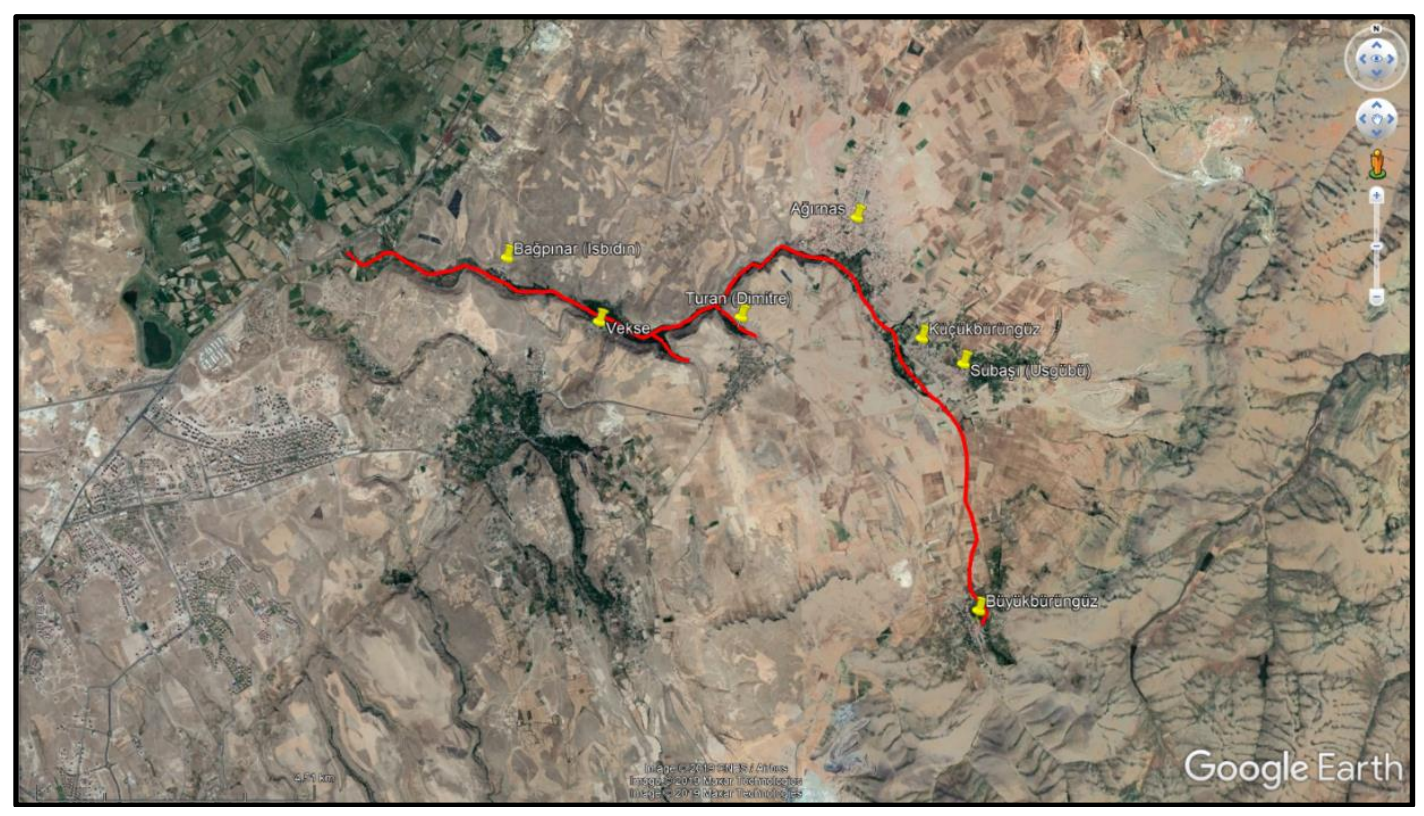

Resim 1: Koramaz Vadisi ve Yerleşim Yerleri

Strabon Kayseri'ye gerçekleştirdiği ziyarette şehri Eusebia ve Mazaka isimleri ile anmakta, bugünkü Kayseri şehir merkezinin kurulu bulunduğu ovayı bataklık olarak tanımlamakta ve halkın ovaya kıyasla yüksekte kalan bölgelerde yaşadığını anlatmaktadır (Strabon, 2012) . Bu bakış açısıyla 
rakımı şehir merkezinden ortalamada 300 metre fazla olan Koramaz Vadisi'nde o dönemde de yerleşim olduğu iddia edilebilir. Koramaz Vadisi'nin batısında yer alan Kültepe höyüğü de dikkate alındığında binlerce yıldır sürekli iskân gördügüü düşünülebilir. Vadinin Bizans Dönemi'nde de önemli bir merkez olduğu, şehri doğuya bağlayan yolların bir bölümünün buradan geçtiği bilinmektedir. Dönemin önemli Bizans yollarından biri de Sivas yoluna paralel olarak Gesi bölgesi içerisinden geçmekte idi. Gesi ${ }^{1}$, Bizans Dönemi'nde "Kase" bazı kaynaklara göre (Moravcsik ve Jenkins, 1967) "Kasi" olarak adlandırılmaktaydı. VI. Leon Dönemi’nde (886-912) Gesi (Kase), daha önceden Kapadokya Askeri Bölgesinde iken (Theme), Charsianon Askeri Bölgesi (Theme)'ne eklenmiş ve Kayseri ile birlikte Charsianon adlı yeni Askeri Bölgeye dâhil olmuştur. 20. yüzyılın başlarında bölgede yaşayan Rumlar tarafından bölgeye "Nea Kassiane" denilmekteydi, bugün bölgeye Gesi denilmektedir. Kısa bir dönem için de olsa bölgedeki Gesi garnizonu, kendi bölgesinde güvenlik zafiyeti bulunduğu için Pınarbaş1 Piskoposuna ev sahipliği yapmıştır.

Bahse konu Bizans yolu, Gesi'den sonra kuzey doğu istikametinde devam etmekte ve $6 \mathrm{~km}$ sonra Antik Piskoposluk Şehri olan Aragena'ya ulaşmaktadır, Aragena bugün Ağırnas olarak bilinmektedir. Mandae, bugün bir köy olan Üsgübü (Ağırnas'ın 2 km güneyindedir)'deki manastırın adıdır. Bu manastırda Ağırnas piskoposu ikamet ederdi. Bugün Üsgübü olan köyün adı sonraları "Skupi" ve daha önce de "Episkope" kelimelerinden türemiştir (Hild, 1977), bugün köyde hala piskoposluk görüntüsü göze çarpmaktadır. Mandae manastırına bağlı The Forty Martyrs Kilisesi Üsgübü'de yer almakta idi. Bu kilise söylenenlere göre tamamen yıkılmış ve ilkokul yapılırken taşları kullanılmıştır. Kilisenin kalıntıları bugün köyün kuzeyindeki bir tepede yer almaktadır. Yol, Ağırnas'tan sonra Kuzey Doğu istikametinde eski adı ile Sarmısaklı'ya bugünkü adı ile Bünyan'a yönelir (Honigmann, 1935). Koramaz Vadisi'nin Bizans Dönemi’nde de yol güzergâhında yer alması sebebi ile oldukça önemli olduğu açıkça görülmektedir. Resim 2'de Koramaz Vadisi'nden geçen Bizans hatta öncesinde Roma yolunun tahmini güzergâhı gösterilmektedir.

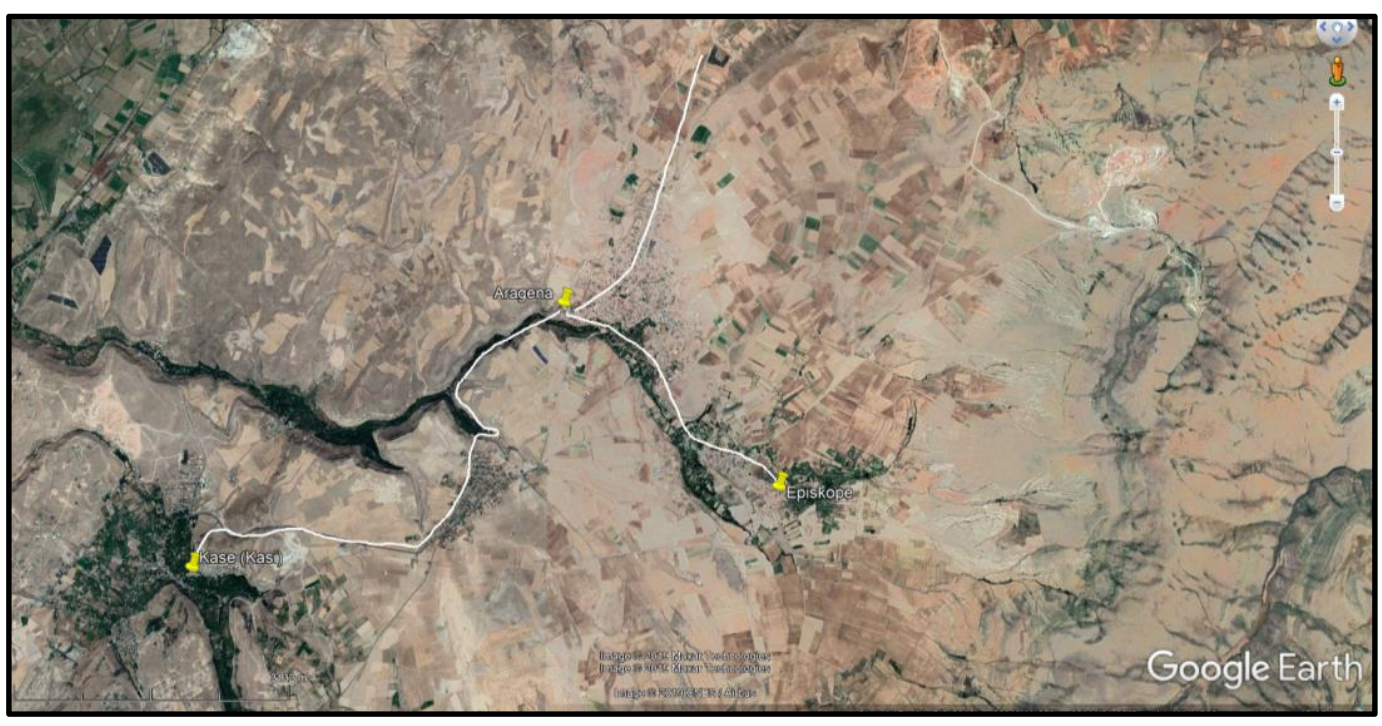

Resim 2: Koramaz Vadisi İçinden Geçen Bizans Yolunun Tahmini Güzergâhı ve Eski Yer Adları

\footnotetext{
${ }^{1}$ Kase (Gesi) Pınarbaşı (Ariaratheia) ile Kayseri (Kaisareia) arasında bulunan bir yerleşim yeri. Hild, kitabında bu yerin bugün Kayseri'nin $13 \mathrm{~km}$ kuzey doğusunda yer alan, çeşitli antik kalıntılar barındıran ve Gesi olarak bilinen yerleşim yeri olduğunu iddia etmektedir. Ĕger bu iddia doğru ise antik isim bugün yerel isim olarak yaşamaya devam etmektedir. Pınarbaşı ile Gesi arasındaki mesafe bir piskopos tarafından yönetilmek için oldukça fazladır, Hild iddiasını güçlendirmek için Pınarbaşı Piskoposunun güvenlik nedeni ile Gesi'ye yerleştiğini iddia eder(Zgusta, 1984).
} 
Koramaz Vadisi'nde içerisinde yer alan fresklerden, nişlerden ve yapılış şekillerinden yola çıkarak Bizans Dönemi'ne tarihlenen şu ana kadar tespit edilmiş toplamda 40 adet kaya kilise bulunmaktadır. Bunlardan içerisinde yer alan freskleri en iyi korunmuş ve günümüze kadar ulaşabilmiş en önemli kilise daha önce N. Karakaya tarafından Isbıdın Kaya Kilisesi ${ }^{2}$ olarak takdim edilmiş kilisedir. Kilise tahmini XI-XIII. yüzyıllar arasına tarihlenmektedir (Karakaya, 2013), (Straub vd., 2019). Bu kiliseye ilave olarak bugünkü adı ile Subaşı (Üsgübü) köyünde yer alan bir kaya oyma manastır da dikkat çekmektedir (Karakaya, 2014). Kaya oyma kiliselere ilave olarak günümüze kadar ulaşabilmiş iki adet de büyük kilise bulunmaktadır. Bunlar Vekse Rum Kilisesi ve 1857 yılında inşa edilmiş Ağırnas Kilisesi’dir (Kayseri Taşınmaz Kültür Varlıkları Envanteri, 2008).

Koramaz Vadisi'nin yerel adı ile Akbin Deresi olarak bilinen bölgesinde karşımıza çıkan kaya mezarlar, arkosolium mezarlar, columbarium mezarlar, vadinin üst kısmında yer alan platoda yer alan inhumasyon amaçlı khamosorion tipi kaya lahitleri vadinin Roma Dönemi'nden başlamak üzere Bizans Dönemi'nde de bir mezarlık olarak kullanıldığını göstermektedir (Resim 23). Vadide yer alan anıtsal tasarıma sahip mezar kapıları dikkatle incelendiğinde yapıların Roma Dönemi mimari unsurlarını içerdiği benzerlerine kıyasla rahatlıkla görülebilmektedir (Resim 10, 24, 25, 26). Vadiyi merkeze oturtup $5 \mathrm{~km}$ yarıçaplı bir daire çizildiğinde içerisinde kalan Kültepe, Höngele, Aydos, Kazlar, Andon adları ile bilinen bugün terkedilmiş ve sadece yüzeysel kalıntılar barındıran antik yerleşkelerin Roma ya da daha önceki dönemlerde aktif yaşam barındırdıkları rahatlıkla iddia edilebilir. Roma Dönemi'nde mezarlıkların hastalık oluşturma endişesi ile yerleşim yerlerinin hemen dışında yapılmaları geleneği göz önüne alındığında Koramaz Vadisi'nin tüm bu antik yerleşkelerin ortak mezarlığı olduğu düşünülebilir. Vadinin çevresinde ve içinde karşımıza çıkan kağnı yolları da bu iddiayı aslında teyit etmektedir (Resim 22). Tüm bunlara ilave olarak vadinin üst kısmında yer alan platoda $5 \mathrm{~km}$ 'lik yarıçap içerisinde 14 adet tümülüs rahatlıkla gözlemlenebilmektedir.

\section{Roma Dönemi Ölü Gömme Gelenekleri, Kremasyon Gömü ve Columbarium Mezarlar}

Roma Dönemi'nde yaşam sonrasında hayatın devam ettiğine inanılırdı, bu nedenle doğum nasıl kutlanıyorsa ölüm de öyle kutlanılmaktaydı ve cenaze törenleri Roma'da oldukça önemli ritüeller barındırmaktaydı. Roma bu konuda oldukça tutucu bir geleneğe sahiptir. Roma'da sosyal statü ile cenaze töreni ve hatta defin yeri bile değişebilmektedir. Elit cenaze merasimleri ile elit olmayan grubun cenaze merasimleri arasındaki farklılaşma, ekonomik nedenler ile toplu gömülmenin elit olmayan gruplara ait bir gelenek olarak zaruri kabulüne gitmiştir. Ölünün defin işlemleri ise dönemden döneme değişmekle birlikte gömme geleneği olarak inhumasyon (toprak altına gömmek), kremasyon (ateşle yakma), doğaya terk ve mumyalama yöntemlerinin kullanıldığı bilinmektedir (Civelek, 2007). Roma'da erken dönemlerde inhumasyon ve kremasyonun birlikte uygulandığı görülmektedir. Roma on iki tablet kanunları ölünün şehrin içine gömülmesini yasaklamıştır. Bunun en büyük nedeni ölü bedenden sağlıklı bedenlere bulaşabilecek salgın hastalıkların önlenmesidir. Bu nedenle Roma Dönemi'nde mezarlıklar şehrin dışına yapılmıştır (Civelek, 2007). Roma'da kremasyon gömme tekniği milattan önce 4. yüzyılda başlamış ve milattan sonra 3. yüzyılda terkedilmiş bir gelenektir ${ }^{3}$. Kremasyon gömme geleneğinde, ölü beden ziynet eşyaları ile birlikte dikdörtgen şeklinde hazırlanmış odun yığını üzerine törenle konulur ve yakılırdı. Bedenin tamamı yanmaz ve yaklaşık 2,5-4 kg ağırlığında yanmayan kemikler kalırdı, geriye kalan kül ise toplanarak urne ya da ostothek adı verilen kaplara doldurulurdu. Kremasyon gömme geleneği Resim 3'te gösterilmiştir.

\footnotetext{
${ }^{2}$ Duvar resimleri XI-XIII. yüzyıllara tarihlenmektedir. Kilise, Ispıdın (Bağpınar) köyünü içine alan vadide, köyün batısında, vadinin güney yamacında yer alır. Kilise batısında bulunduğu Ispıdın köyüne $3 \mathrm{~km}$ mesafededir. Yol seviyesinden $15 \mathrm{~m}$ kadar yükseklikteki yamaca oyularak yapılmıştır (Karakaya, 2013).

${ }^{3}$ Kremasyon gömü Demir Çă̆ı'nda da görülmektedir (Yiğitpaşa, 2010, 2011).
} 


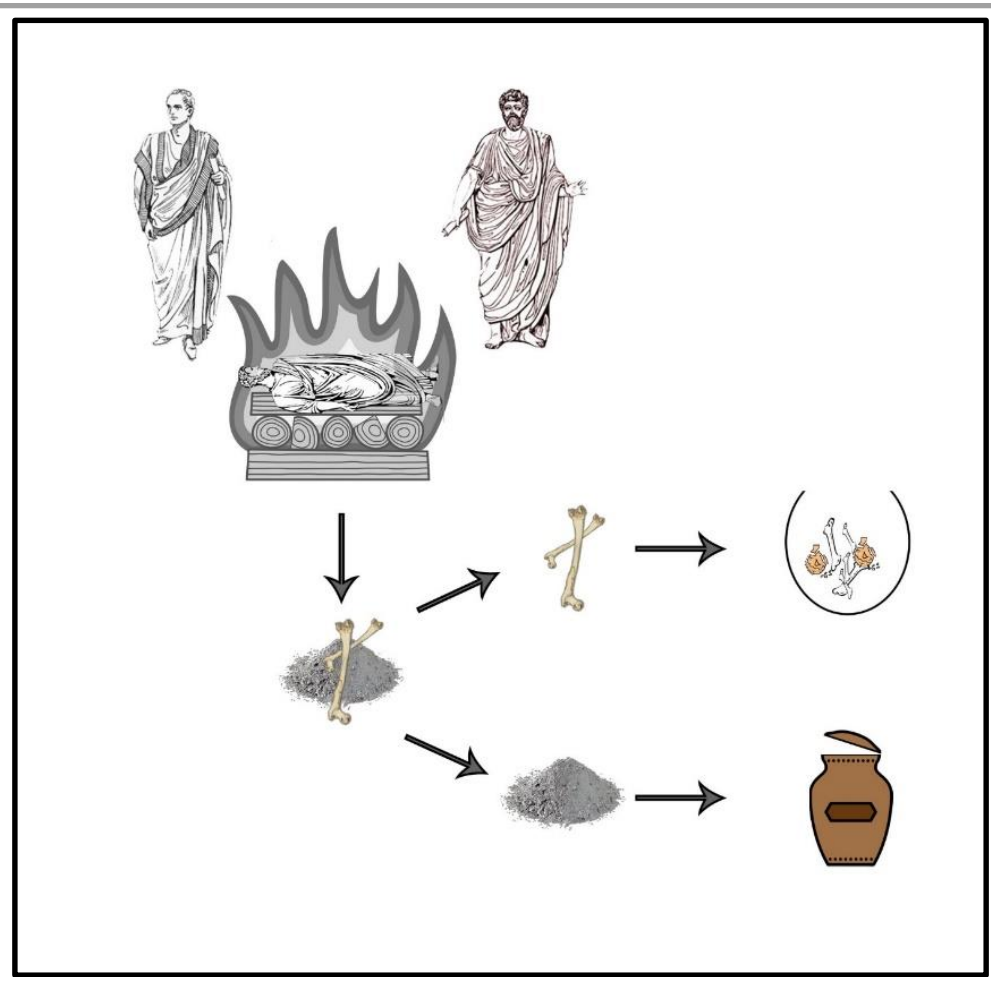

Resim 3: Kremasyon Süreci

Urneler (ya da urna) kapaklı ya da kapaksız olabildiği gibi, camdan, metalden ya da mermerden de yapılabilmekteydi. Bazı urnelerin üzerinde ölünün kimliğinin yazılı olduğu alanlar da bulunmaktaydı (Akkurnaz, 2016), (Yiğitpaşa 2010, 2011). Kül dolu urne daha sonra mezar odasına ya da columbarium mezarında yer alan urne nişine konulurdu veya isteğe göre gömülürdü, yanmayan kemikler ise yine mezar odasındaki silolarda saklanırdı (Resim 19). Mumyalama ise bedenin onurlandırılması manasına gelmektedir ve görece maliyetli bir defin tekniğidir, bu nedenle de varlıklı kişiler haricinde halk arasında uygulanmamıştır (Civelek, 2007).

Kremasyon neticesinde ölüden arta kalan küllerin doldurulduğu urnelerin ölüye gösterilen sayg1 gereği muhafazası önemli bir konudur. Bunun için mezar kazmak, külü inhumasyonda olduğu gibi toprak altına gömmek oldukça masraflı bir yöntem olmaktadır. Nüfusun arttığı, mezarlık alanlarının dolmaya başladığı göz önüne alınırsa toplu olarak defin yapılabilecek çözüm arayışlarının gayet doğal olarak ortaya çıktığı anlaşılmaktadır. Roma'da, gittikçe büyüyen devasa kentleşme neticesinde, geleneksel mezarlıklar tıka basa dolmuş, yüksek miktarda cenaze ve defin işlemi yapılan büyük şehirlerde aynı gömü çukuruna birden fazla bireyin gömülmesi, hatta bazen aynı gömü çukurunun definler üst üste gelecek şekilde birkaç kez kullanılması olağan karşılanır hale gelmişti (Borbonus, 2014).

Roma toplumu, artan defin maliyetleri ve kapasite doluluğu nedenleri ile Augustus Dönemi'nde yer altına ya da kaya içlerine oyulan toplu mezar nişlerinde urnelerin muhafaza edilmesi yöntemini kullanmaya başlamışlardır. Bu amaç için yapılmış olan yapılara columbarium mezar denilmektedir. $\mathrm{Bu}$ yeni gelenek toplum ve cenaze masraflarını yöneten modern organizasyonlar tarafindan benimsenmiş ve ölen kişilerin onurlu bir biçimde, güzel bir tören ile tek başına bir mezara gömüleceği cenaze sigortası türevi fonksiyonlar geliştirmişlerdir (Borbonus, 2014). 


\section{Columbarium Mezarlar}

Columba kelimesi Latince güvercin anlamına gelmektedir, columbarium ise Roma Dönemi'nde güvercin yuvası manasında kullanılmıştır. Columbaria ise columbarium kelimesinin çoğuludur. Columbarium kelimesi aslında columbarium mezarı içerisinde yer alan her bir nişe verilen addır (Gilli, 2017). Romalıların bu anıtsal toplu mezarları güvercin yuvası olarak adlandırmalarının hiç şüphesiz nedeni yapıların esasında güvercinliğe oldukça önemli biçimde benziyor olmalarıdır. Bugün bile bir güvercinlik ile columbarium mezarın ayırt edilmesi oldukça zor ve teknik bir konudur, Romalıların bu ismi neden kullandıklarının aslında açıkça da kanıtıdır. Bu durum, yani columbariumların güvercinlik olarak uzun yıllar kullanılmış olması ve ilk fonksiyonunun halk tarafindan bilinmiyor olması columbariumların günümüze kadar görece daha az defineci tahribatına uğramasına vesile olmuştur. Güvercin beslenen yapılar ile columbariumların karıştırılmaması için columbarium mezarı ifadesi kullanılmaktadır (Borbonus, 2014). Columbarium mezarlar sadece görsel olarak benzersiz olmakla kalmayıp, biyolojik ailelere ve aynı evde ikamet eden kişilere toplu defin hizmetleri sağlanan Roma'nın bilinen ilk organize toplu mezarlarıdırlar (Borbonus, 2014).

Columbarium mezarlar, ölü yâd etme ihtiyaçları sonucu ortaya çıkmış benzersiz yapılar olup, hitap ettiği kesimin toplumsal durumuna dair ipuçları da sunmaktadırlar. Columbarium mezarlar duvarlarına işlenmiş çok sayıda mezar nişleri nedeni ile günümüze kadar çok yıpranmış olarak ulaşmış olsalar dahi diğer mezar yapılarından bu nişler sayesinde kolayca ayırt edilebilmektedirler. Columbarium kelimesi aslında Roma Dönemi yazılı kaynaklarında devasa güvercinlikler içerisindeki barınma nişi olarak yer almaktadır, mezar abidesi olarak kullanımına delil ise Roma Dönemi'nden kalma mezar tabelası kayıtlarıdır. Bu kayıtlarda her bir nişin kime ait olduğu görülebilmektedir. Columbarium mezarlarda sadece küller değil aynı zamanda yakılmış insan bedeninden kalan kemik parçaları da yer depolarında (silo) saklanmakta, küller ise iç duvara oyulmuş mezar nişlerinde özel topraktan yapılmış kaplarda saklanmakta idi (Resim 42), (Borbonus, 2014). Aşağıda yer alan Resim 4'de Roma Dönemi'ne tarihlenen büyük ve önemli bir columbarium mezarı görülmektedir.

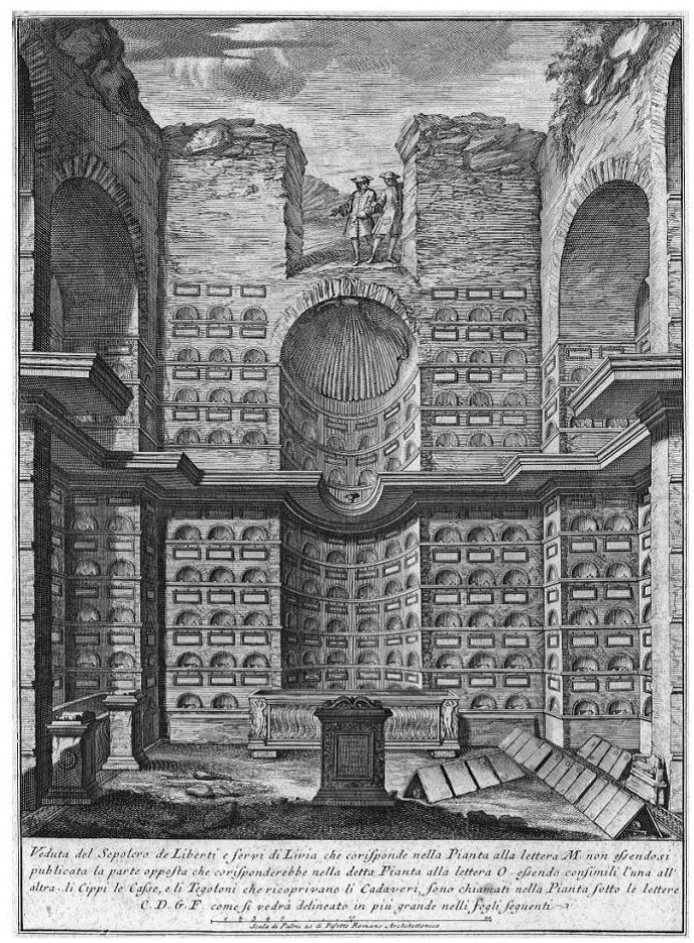

Resim 4: Livia Columbarium Mezarı Doğu Duvarı (Borbonus, 2014) 
Columbarium mezarlar kapıları kapalı, toplu defin anıtlarıdır. Bu yapıların iç duvarlarına kazılmış olan mezar nişlerine yakılmış olan ölünün külleri bir toprak kap içerisine yerleştirilerek dizilirdi. Columbarium mezarlar, elit olmayan Roma vatandaşlarının, genellikle de kölelerin ve aristokrat evlerinde hizmet eden sonradan özgürleşmiş kölelerin küllerinin saklandığı toplu mezar alanlarıdır. Şurası kesindir ki columbarium mezar sakinleri, elit sınıftan ve Roma politik elitleri sınıfından değillerdir. Columbarium mezarların inşasının elit olmayan kitleden bir yönetici tarafından ya da aristokrat liderlerce yönetildiği bilinmektedir. Columbarium mezarlar büyük kitlelerin kullandığı bir defin ortamı olamazlar, çünkü bulundukları bölgelerdeki sayıları o bölgede yaşayan tüm insanları kapsayacak kadar çok değildir. Bunun yerine belirli bir zümrenin örneğin elit toplumun çalıştırdığ1 işçilerin defin yeri olabilirler (Borbonus, 2014). Toplu defin mezar anıtı sayesinde kitleler sosyal olarak bir etkileşim içerisine girmektedirler. Bireyler, aileler veya arkadaşlık grupları bu vesile ile bir araya gelmişler ve sosyal topluluklar oluşturmuşlardır (Borbonus, 2014). Roma'da elit olmayan sınıf hakkında maalesef gerçekçi bir yazılı kaynak bulunmamaktadır, bunun yerine elitler tarafından yazılmış abartılı ve klişe bilgiler bulunmaktadır. Bundan dolayı, tarihi değerine rağmen ne yazık ki columbarium mezarlar hakkında teferruatlı bir bilgi kaynaklarda yer almamaktadır. Bunun altında yatan nedenler; kalıntıların kötü durumda olması, tipolojik farklılıklar barındırması ve geleneksel arkeoloji anlayışının elit kültüre odaklanmış olması olarak sıralanabilir. Columbarium mezarların tarihlendirilmesi genellikle mümkün olamamaktadır. Bunun temel nedeni bu yapıların inşa edilirken oldukça kalitesiz bir işçilikle inşa edilmiş olmaları ve urne kaplarının ya da ölü hediyelerinin yeteri kadar ele geçmemiş olmasıdır (Borbonus, 2014). Tüm bu durumun neticesi olarak columbarium mezarların varlığının değeri yeterince bilinememiştir. Aşağıda yer alan Resim 5'de oldukça tahrip olmuş bir columbarium mezar görülmektedir.

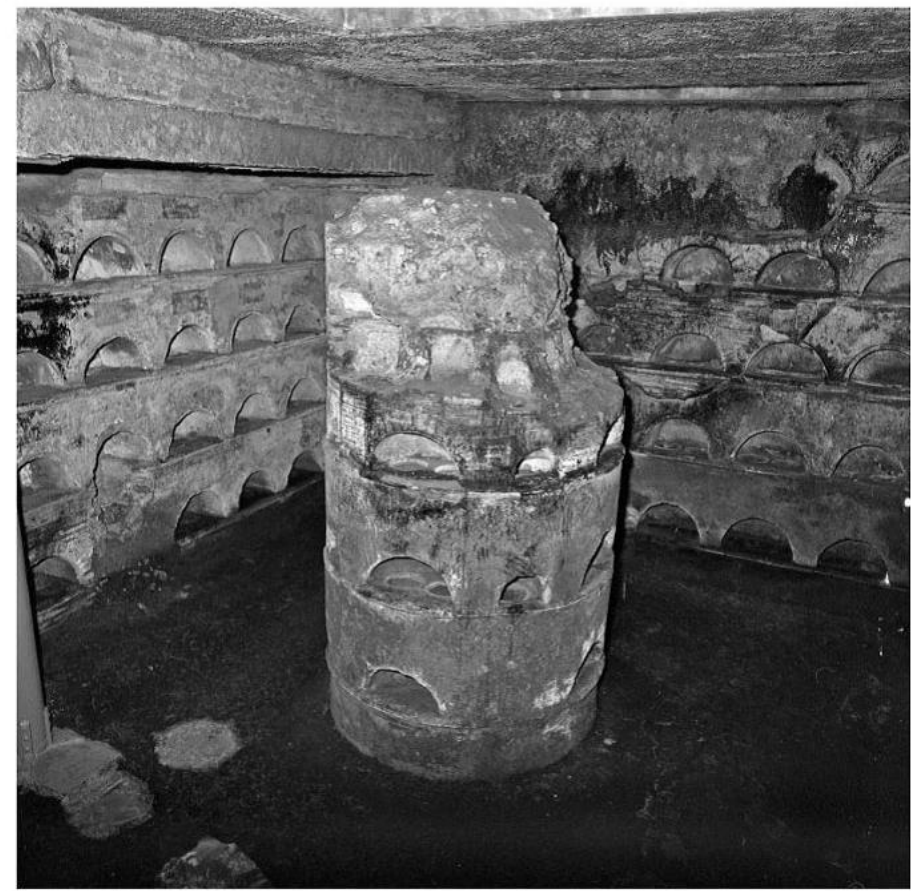

Resim 5: Sepulcrum Scipionum Yakınındaki Columbarium Mezarı (Borbonus, 2014)

Roma'nın kentsel nüfusunda, toplu organizasyon ve gömülme, sınıfsal ayrılıkların ortaya çıarabileceği problemlere bir nebze de olsa çözüm yönünde destek sağlamıştır. Birlikte olma ve yardımlaşma atmosferi sayesinde insanlar arasındaki dayanışma artmakta ve sosyal şikâyetler baskılanmaktadır. Columbarium mezarlar bu dayanışmanın fiziksel tezahürü olarak Augustus Dönemi'nde ortaya çıkmışlardır. Columbarium mezarların bulunduğu çevreden izole edilmiş bir 
biçimde inşa edilmiş olmaları tipik bir Augustus Dönemi anlayışını yansıtmaktadır. Columbarium mezarların yer altında inşa edilmiş olmaları, onların toplu defin bölümlerinin çevredeki yerleşimlerden tam izolasyonunu mümkün kılmıştır (Borbonus, 2014). Columbarium mezarların ilk yapılmaya başlandığı dönem olan Augustus Dönemi'nin sonlarında, yapıların basit bir biçimde inşa edildiği görülmektedir. Augustus Dönemi sonrası yapılan columbarium mezarların daha ileri fonksiyonlar kazandığı, Tiberian sonrası yapılan columbarium mezarların ise toprak üstü columbarium mezarlara evrildiği görülmektedir (Borbonus, 2014). Yer altı columbarium mezarlar, Augustus Dönemi'nde ortaya çıkmış benzersiz yapılar olup, bir ya da iki nesil boyunca yapılagelmişlerdir. Columbarium mezarlar mimari tasarım olarak gömü nişlerinin benzer veya eşit şekil ve büyüklükte yapıldığı yapılardır. $\mathrm{Bu}$ sayede her bir nişe yerleştirilen kişiler görsel olarak aynı seviyede bulunmaktadırlar. Defin nişlerinin bağımsız birer niş olarak kazılmış olmaları onları birbirinden bağımsız kılmamaktadır. Arka arkaya dizilmiş, tekrarlanan nişler sonsuz bir birliktelik hissini tüm columbarium mezar içerisine görsel olarak yaymaktadır. Tüm columbarium mezarların orijinal kapasitelerinin, kullanım sürelerinin ve ortalama ölüm oranının kestirimi ile nüfus büyüklügünü hesaplamak mümkün olabilir. Columbarium mezarlarının mimari tasarımları kendilerine has bir karakteristiğe sahiptir ve benzersizdir, bununla birlikte toplu defin organizasyonları da yine columbarium mezarlarla birlikte ortaya çıkmış ve sadece buralarda uygulanmıştır. Columbarium mezarların genellikle collegia adıyla bilinen bir organizasyon tarafından idare edildiği bilinmektedir. Sosyal kulüpler olarak da değerlendirilebilecek collegiaların en önemli fonksiyonu defin işlemleri idi (Borbonus, 2014). Columbarium mezarlar yılın belirli günlerinde ölülerin akrabaları tarafindan ziyaret edilirdi, Resim 6'da bir columbarium mezarda gerçekleşen ziyaret resmedilmiştir.

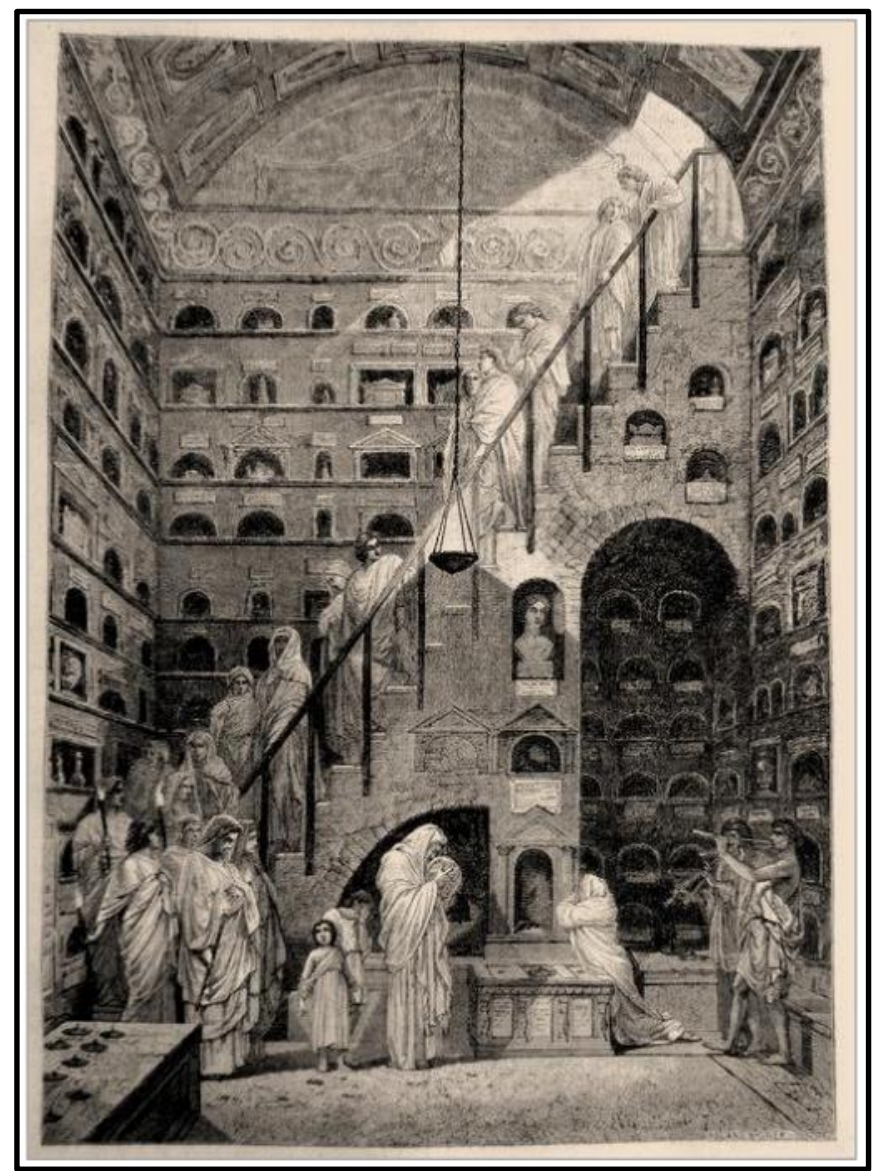

Resim 6: Louis Hector Leroux Sanatsal Columbarium Çizimi, Roma Appian Yolundaki Columbarium Mezarda Anne ve Oğlu, Musee de la Princerie, 1878.

Turkish Studies - Historical Analysis

Volume 14 Issue 3, 2019 
Her bir urne nişinin genellikle pişmiş topraktan yapılmış, ağzı kapatılmış ve genellikle iki tane ölü külü saklama kabı (urne) içerdiği bilinmektedir. Nişlerin miktarı, bölgede yaşayan elit olmayan toplumun ölüm ve defin kapasitesine dair bir fikir verebilmektedir. Columbarium mezar duvarlarındaki mezar nişleri bir ila on arasında değişen sıralar halinde kazılırdı, bu nişler bazı örneklerde üçgen şeklinde olabilmektedir ve her bir niş bir ila altı arasında değişen toprak kap içerebilmektedir (Resim 14, 41), (Borbonus, 2014).

Columbarium mezarların genellikle Roma'ya giden anayolların yakınlarında inşa edildikleri bilinmektedir. Columbarium mezarlar her ne kadar yer altında inşa edilmiş olsalar da, ana yoldan saparak columbarium mezarlara ulaşmaya çalışan bir ziyaretçinin bu yapıları fark edebileceği kadar dışarıdan görünen bir kısımları da var idi. Ziyaretçi, dışarıdan gördüğü yapılar ile hangi columbarium mezarın kendi ailesine ait olduğunu bilebiliyordu. Columbarium mezarların kilitlenebilir bir kapıları bulunuyordu. Çevreyle olan görsel bağımsızlık, yerleşim yerlerinden fark edilmeyen yapılarının aksine columbarium mezarların içi tam bir kitlesel tören alanıdır. Roma Dönemi anıtsal mezarlar, içinde yatan kişinin şanına uygun şekilde gösterişli yapılırlardı, ancak gözden ırak columbarium mezarlarda böyle bir kaygı bulunmamakta ve görsel açıdan oldukça sade olmaktadırlar. Columbarium mezarların yapılış şekilleri incelendiğinde minimum maliyetle maksimum kapasite hedeflendiği anlaşılmaktadır (Borbonus, 2014).

Columbarium mezarların çevreden izole yapıları sayesinde, hem mahrem hem de toplu ölüm yâd etme alanı özellikleri taşırlar. Columbarium mezarlar, sakinlerinin ölüm ya da doğum günlerinde ya dini tatil günlerinde (parentalia) ziyaretçi akınına uğrarlardı. Her ne kadar ziyaretçileri olsa da yer altında olmaları, çevreden izole olmaları nedeni ile görece ziyaretçi sayıları hep düşük olmuştur. Bu günlerde columbarium mezarlara genellikle güller bırakılırken, günümüze kadar ulaşan pişmiş topraktan yapılmış lambalar da bulunmuştur. Bu lambaların ölünün columbarium mezar gibi karanlık ortama yolunu bulabilmesi inancına dayanılarak hediye edildiği bilinmektedir. Lambalar şayet yeterli alan varsa nişlerin içerisine yoksa nişlerin önüne veya sütunlara yakılarak dizilirlerdi, ortamda bir huşu oluşturup gelen kitleyi teskin ederdi. Bu özel günlerde ayrıca columbarium mezarların dışından bir tünel içerisinden (libasyon oluğu) defin alanına şarap döküldüğü de bilinmektedir (Resim 18), (Borbonus, 2014).

Columbarium mezarların bir anda ortaya çıktıklarını düşünmek doğru değildir, görünüm benzerlikleri dikkate alındığında columbarium mezarların bir yapıdan esinlendiği düşünülebilir. Etrüsklere ait olduğu öne sürülen columbarium mezarlar, kayadan kesilmiş dairesel yapılardır ve içlerinde kare ya da üçgen formlu, çok sayıda düzensiz nişler bulunur. Etrüsklere tarihlendirilen bu yapılar kentlerden uzakta, erişimi zor olan alanlarda çok sayıda bulunmaktadırlar (Borbonus, 2014). Resim 7'de İtalya'da yer alan ve Etrüskler tarafından yapıldığı bilinen columbarium mezarından bir görsel yer almaktadır. 


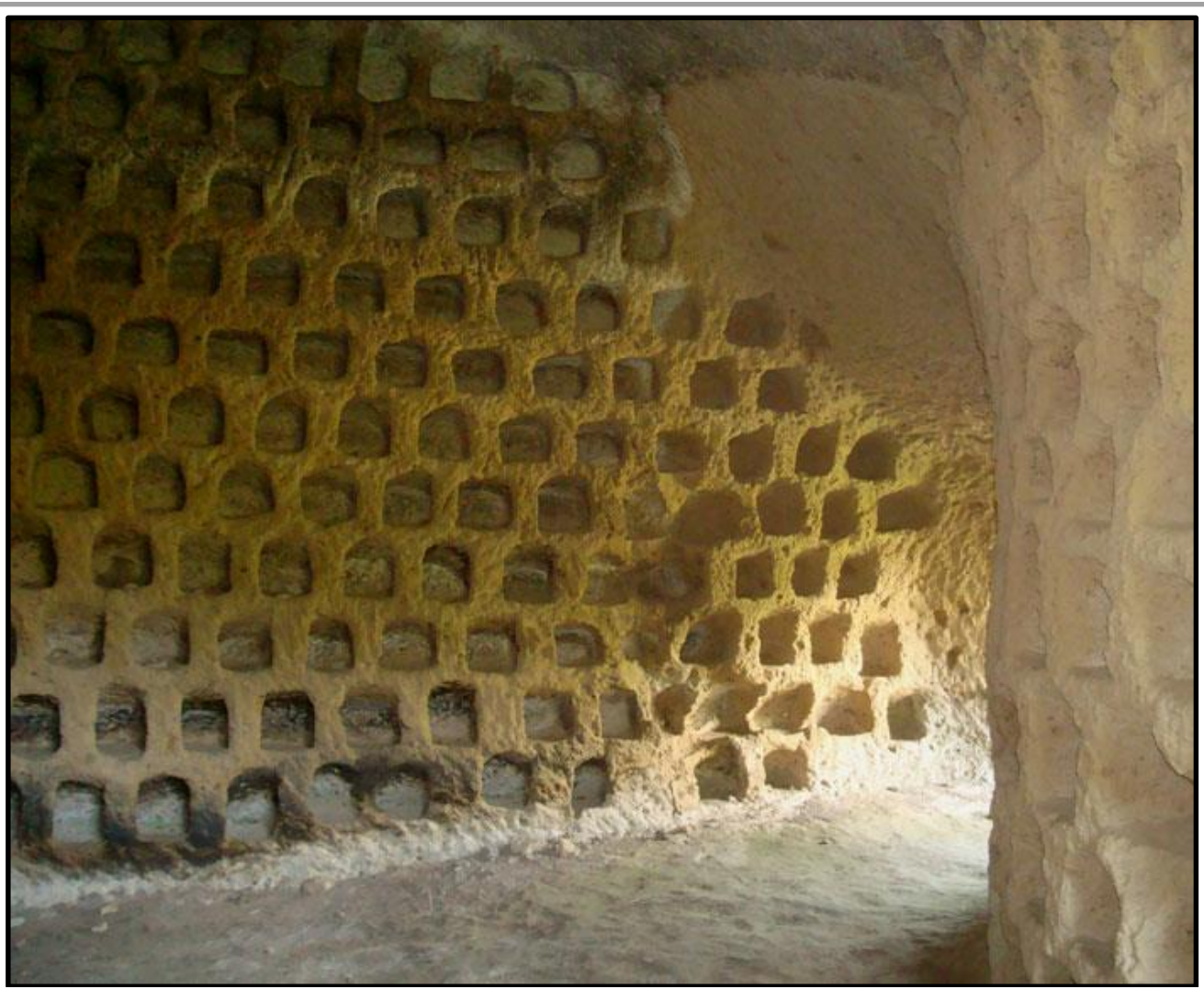

Resim 7: Etrüsk Columbarium Mezar Örneği, Güney Toskana, İtalya.

Bazı columbarium mezarların kendi içerisinde çok sayıda iç odaya sahip olduğu, bu odaların kapılarının zamanında kapalı olduğu anlaşılmaktadır, bu odaların aileler veya farklı gruplar için oluşturulmuş özel columbarium mezar iç odaları olduğu düşünülmektedir (Borbonus, 2014).

Bilinmektedir ki columbarium mezar sakinleri defin, kremasyon ve cenaze töreni gibi harcamalar için columbarium mezar yönetimine bir miktar para ödemekte idi. Columbarium mezarlarda mezar nişlerinin altına bir plaka üzerinde kişinin bilgileri yazılmakta, bazı columbarium mezarlarda ise kişinin ismi doğrudan urne üzerinde yazılmaktaydı. Bazı önemli columbarium mezar sakinleri ise bunun da ötesinde bazı şahsi malzemelerini de columbarium mezara koydurabiliyordu. Columbarium mezara defnedilen her bir insan, kremasyon sonrası kalan küllerin içine konulduğu pişmiş topraktan yapılmış kapların depolanabildiği bir urne nişine sahip olmakta idi. Bununla birlikte columbarium mezar sakinlerinin columbarium mezarda urne nişi kazmalarına da müsaade edilmekteydi. Columbarium mezar inşa eden ve yöneten merkezler, tüm columbarium mezar sakinlerinin eşit hizmet almasını ve eşit muamele görmesini garanti altına alıyorlardı. Pratikte columbarium mezara gömülecek olan kişilere yer tahsisi tamamen rastgele yapılmamakta idi, örneğin bir columbarium mezar yönetimi çekiliş düzenleyerek şanslı kişiye altı tane yer seçme hakk1 vermiştir. Bunun da ötesinde bazı columbarium mezar yönetimleri iyi yerleri parayla satmıştır (Borbonus, 2014).

Columbarium mezarlar, Roma'nın son dönemlerinde Hristiyanlık akımlarının artması ile sona eren kremasyon geleneği ardından kullanım dışı kalmışlardır. Bazı columbarium mezarlar ise inhumasyon gömü için kullanılacak şekilde adapte edilmişlerdir, bunun için columbarium mezarların zeminlerine ve duvarlarına geniş defin nişleri ya da çukurları kazılmış veya nişler genişletilerek birleştirilmiş ve beden sığacak hale getirilmişlerdir (Resim 17), (Borbonus, 2014). 


\section{Koramaz Vadisi Columbarium Mezarları}

Bu çalışmada Koramaz Vadisi içerisinde bulunan Ağırnas Mahallesi sınırları içerisinde kalan yerelde Akbin Deresi olarak adlandırılan bölgede yoğunlaşan ama tüm vadi içerisinde dağılmış olarak bulunan toplam 21 adet columbarium mezar olduğu düşünülen insan eli ile kayaya oyulmuş yapılar incelenmiştir. Bu yapıların 18 tanesinin tek bir bölgede bitişik olarak yapıldıkları görülmektedir. Fakat vadi içerisine dağılan 3 tane farklı konumda columbarium mezar da bu çalışmada incelenmiştir, bu durum aslında olası yeni columbarium mezarların ortaya çıkarılabileceğini göstermektedir. Resim 8'de columbarium mezarların Koramaz Vadisi içerisindeki dağılımı görülmektedir. C5, C6 ve C7 columbarium mezarlarının geriye kalan 18 columbarium mezardan uzakta konumlandığg görülmektedir. $\mathrm{Bu}$ columbarium mezarların çevresinde yapılacak detaylı araştırmaları takiben yeni columbarium mezarların bulunabileceği düşünülmektedir. Resim 9'da ise Resim 8'de konumları detaylı olarak görülemeyen 18 columbarium mezar ayrıca gösterilmektedir.

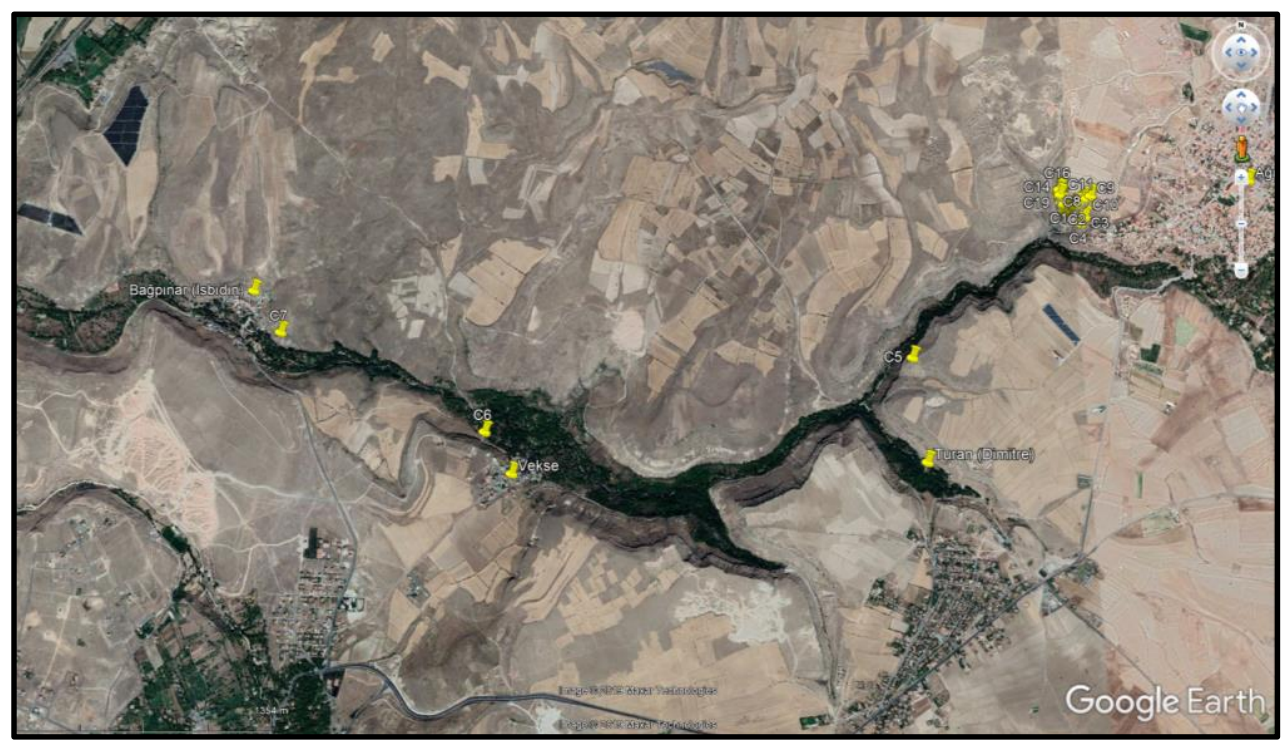

Resim 8: Koramaz Vadisi Columbarium Mezarları

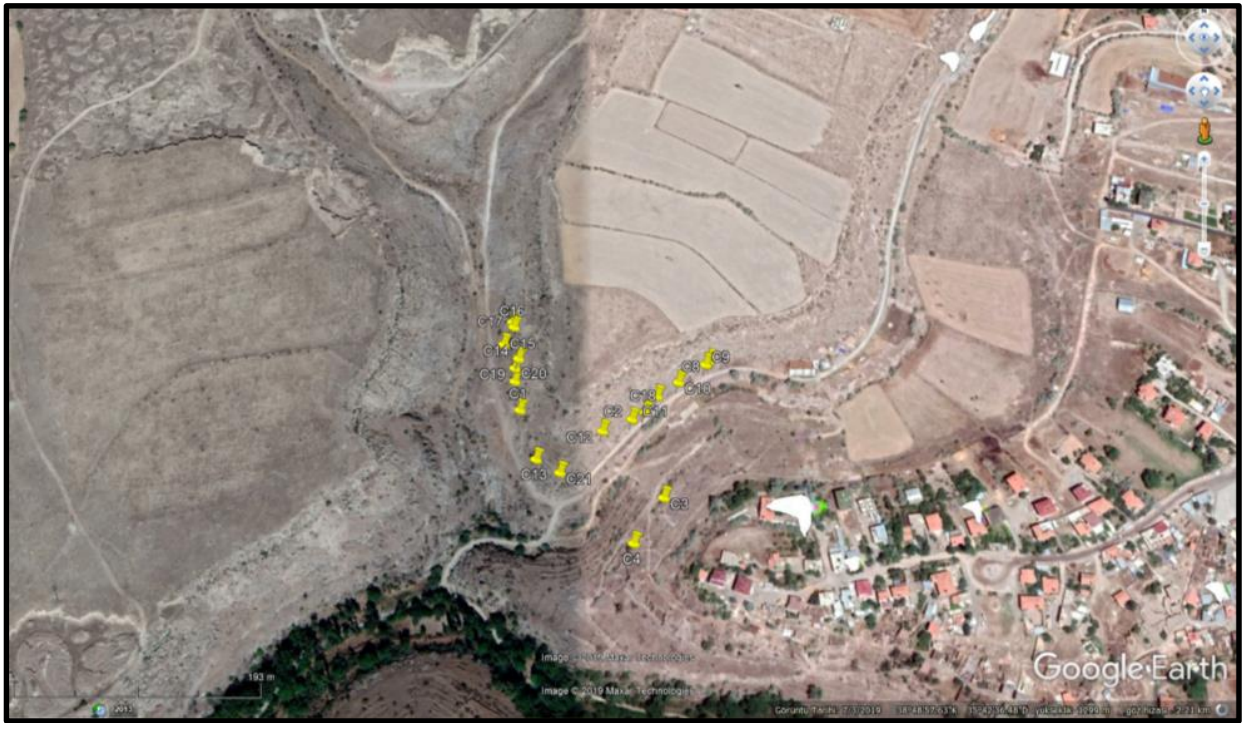

Resim 9: Koramaz Vadisi Columbarium Mezarları (Akbin Bölgesi)

Turkish Studies - Historical Analysis

Volume 14 Issue 3, 2019 
Koramaz Vadisi'nde yer alan columbarium mezarlara dair ilk tespit Eric Gilli tarafindan gerçekleştirilmiştir. Ancak Gilli'nin çalışması sadece bir ön tespitten ibarettir ve genel ifadeler içermektedir (Gilli, 2017). Koramaz Vadisi’ndeki kaya oyma yapılar bir bütün olarak incelendiğinde aslında yapıların zamanla sürekli fonksiyon değiştirdiği görülmektedir. Örneğin Roma Dönemi'nde kaya mezar olarak yapılmış bir kaya mezarın zamanla kiliseye dönüştüğü ya da columbarium mezar olarak kullanılmış bir yapının fonksiyonunu yitirdikten sonra zamanla doğal olarak güvercinlik olarak kullanıldığ durumlar söz konusu olmuştur (Resim 25). Bir diğer senaryoda ise columbarium mezar sonradan şıra haneye dönüştürülmüştür (Resim 36$)$. Bölgede yer alan yapıların güvercinlik olarak ele alındığı çalışmalar literatürde mevcuttur (Karakaya, 2014).

Columbarium mezarların ilk yapılış amaçları her ne kadar toplu defin alanları olsa da zamanla Roma'da Hristiyanlık akınları ile birlikte kremasyon geleneği terk edilince yapılar fonksiyonsuz kalmışlardır, insanlar bu yapıları tavanlarına açtıkları bacalar ve çeşitli modifikasyonlar ile güvercinlik olarak kullanmaya devam etmişlerdir.

Bazı columbarium mezarların zemininde inhumasyon gömülme için defin çukurları açıldığı görülmektedir. Koramaz Vadisi'ndeki columbarium mezarların sağlam olarak günümüze kadar ulaşabilmiş olanlarında ortak bir kapı mimarisi kullanılmıştır. Vadideki birçok columbarium mezarın giriş kısmı yol çalışmaları ve doğal korozyon nedeni ile yok olmuştur (Resim 27). Columbarium mezarın girişinde dikdörtgen planlı bir odaya ulaşılmaktadır, bu odanın fonksiyonu bilinmemekle birlikte anıt mezarın tören odası olabileceği düşünülmektedir (Resim 11). Bu odadan geçilen başka bir kapı ile columbarium mezar odasına ulaşılmaktadır. Bu mimari anlayışın aslında tüm columbarium mezarlar için ortak olduğu iddia edilebilir, zira karşılama odası olmadan doğrudan girilen columbarium mezarların giriş kısımların yıkılmış olduğu gözlemlenmektedir. Ayrıca vadi içerisinde yer alan columbarium mezarların tamamı ya kubbeli ya da dikdörtgen planlı mimaride inşa edilmişlerdir. Columbarium mezarların tamamında benzer mimari yaklaşım tespit edilmiştir. Bu durum göz önüne alındığında Koramaz Vadisi'ndeki tüm columbarium mezarların ortak bir mimari anlayışla inşa edildikleri iddia edilebilir. Resim 10'da kapısı günümüze kadar ulaşabilmiş columbarium mezarların bazılarında görülen ortak kapı mimarisi gösterilmiştir.

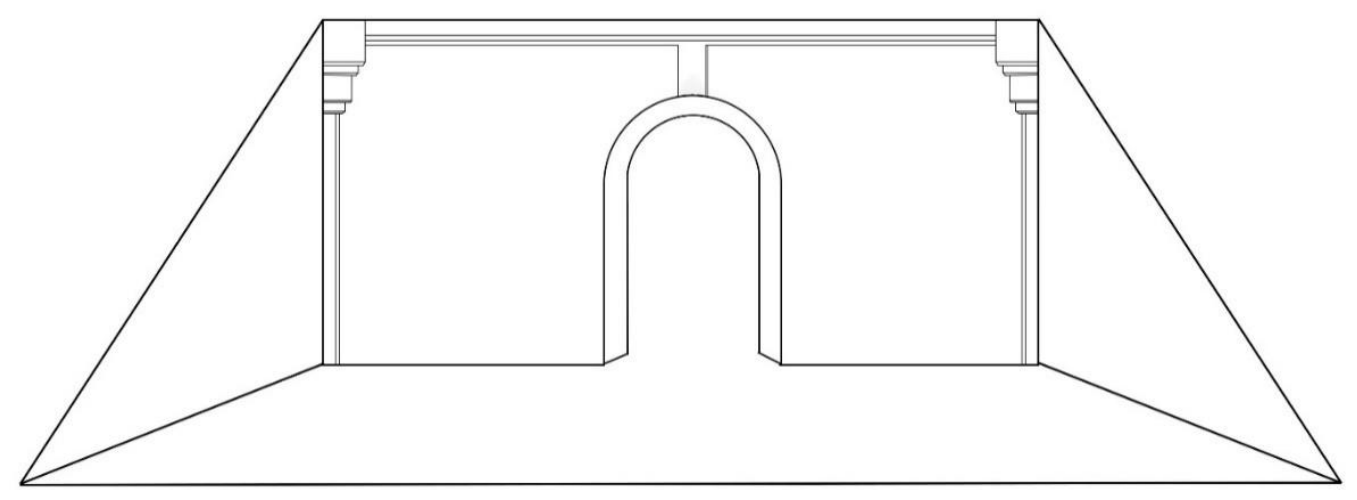

Resim 10: Koramaz Vadisi Columbarium Mezarı Örnek Giriş Kapısı (Resim 26'dan Esinlenerek Çizilmiştir) 


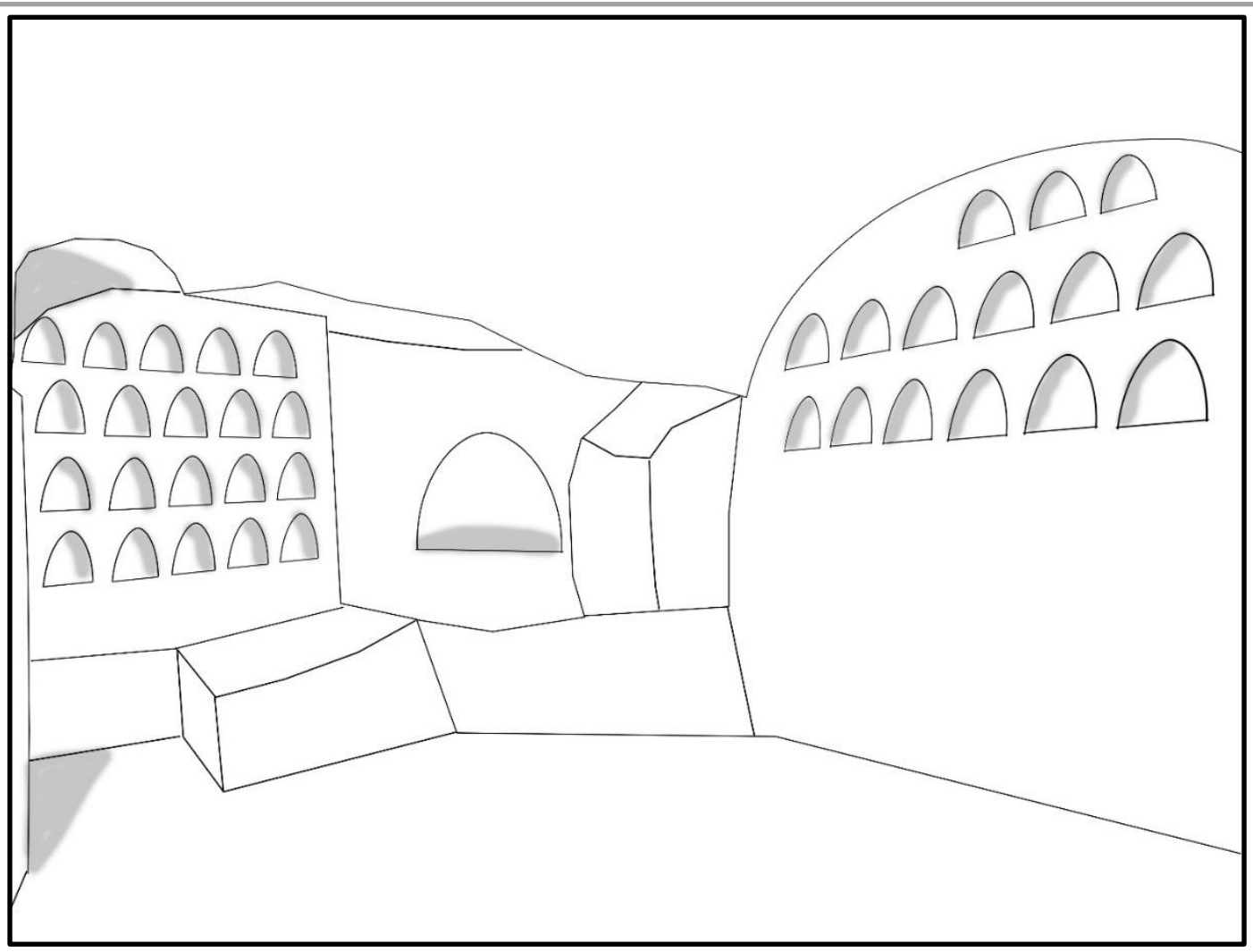

Resim 11: Bir Oda İçerisinden Kapısı Kırılmış Columbarium Mezar Odası (Resim 48)

Bazı columbarium mezarların içerisinde nişlerin birleştirildiği, inhumasyon ya da mumyalama için geniş nişler oluşturulduğu da görülmüştür. Resim 12 'de bu duruma örnek bir illüstrasyon yer almaktadır. 


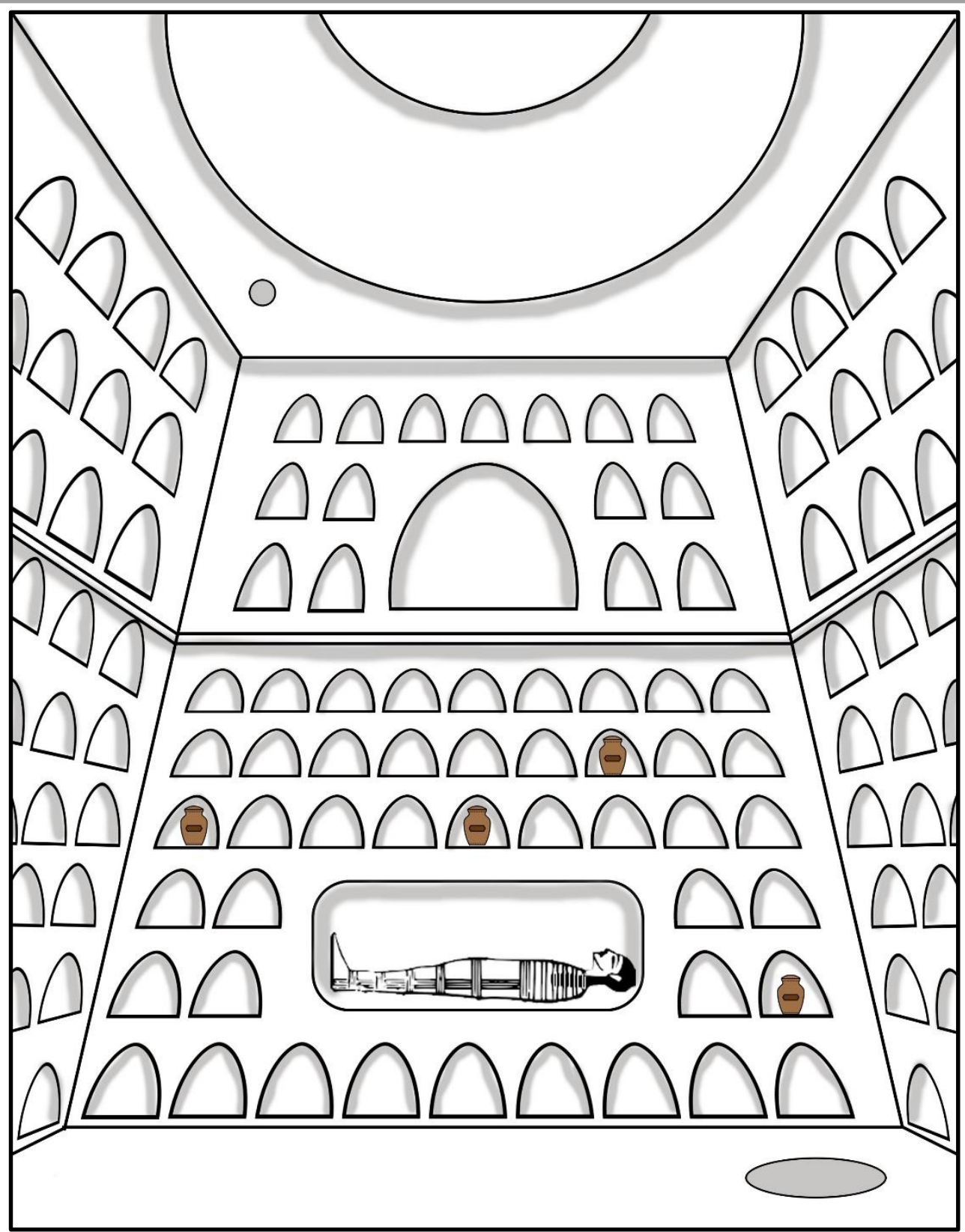

Resim 12: Nişlerin Birleştirilerek İnhumasyon ya da Mumyalama Türü Ölü Gömme İçin Yeniden Düzenlenmesine Dair Örnek (Resim 37)

Bazı columbarium mezarların daha sonra kilise ya da şıra hane olarak da kullanıldığı görülmüştür (Resim 36). Bazı columbarium mezarlara ise sonradan nişler eklendiği özensiz işçilikten anlaşlabilmektedir (Resim 52). Zemini moloz ile örtülü olmayan tüm Columbariumlar Mezarlarda silolar göze çarpmışıır, bu siloların sayısı bazı columbarium mezarlarda altıya kadar (Columbarium C8) ulaşmaktadır, yapılacak kazı ve araştırmalar ile aslında zeminlerde çok daha fazla sayıda siloya ulaşılacağı aşikârdır (Resim 42, 49). Koramaz Vadisi'ndeki columbarium mezarların büyük çoğunluğunun tavanında sonradan kırılarak açıldığı açıkça görülen güvercinlik bacaları yer almaktadır (Resim 47, 50, 52, 56). Güvercinlik bacalarında kullanılan taşlar yine vadinin üstünde yer alan platoda yer alan taş ocakların kesilerek getirilmiştir. Ancak bazı columbarium mezarlarda baca bulunmamaktadır (Resim 36, 39, 60). Bu durum aslında tüm columbarium mezarların güvercinliğe 
dönüştürülmediğini göstermektedir. Columbarium mezar odası içeriden incelendiğinde, anıtsal bir yapıya yakışacak şekilde oldukça özenli bir işçilikle inşa edildiği görülmektedir, fakat bacaların bu kadar özenle yapılmış yapının tavanının merkezinde dahi olmamaları, kırılarak açılmış olmaları bu bacaların sonradan açıldıklarını bariz bir biçimde teyit etmektedir (Resim 41, 52). Resim 13'de yer alan illüstrasyon Resim 52'de gösterilen fotoğrafa aittir ve tavana doğru daralarak yükselen nişler oldukça etkileyici bir tarz oluşturmaktadır.

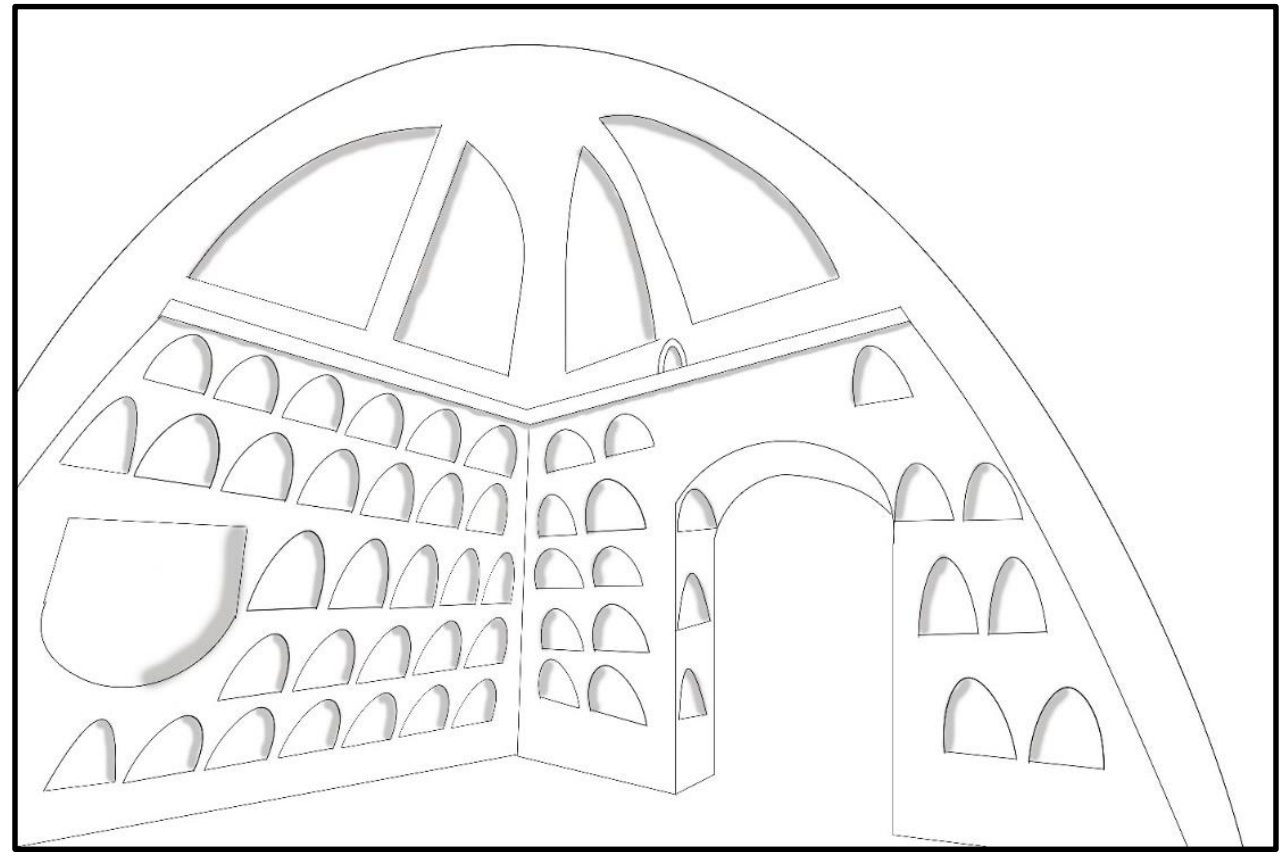

Resim 13: Örnek Bir Columbarium Mezar Odası İçi (Resim 52)

Koramaz Vadisi columbarium mezarlarının içerisinde yer alan nişlerin üçgen ya da yarım elips formunda kazıldığı görülmektedir. Resim 52'de yarım elips formda nişler yer alırken Resim 42'de üçgen formlu nişler görünmektedir. Resim 42'nin illüstrasyonu aşağıda yer alan Resim 14'de gösterilmektedir.

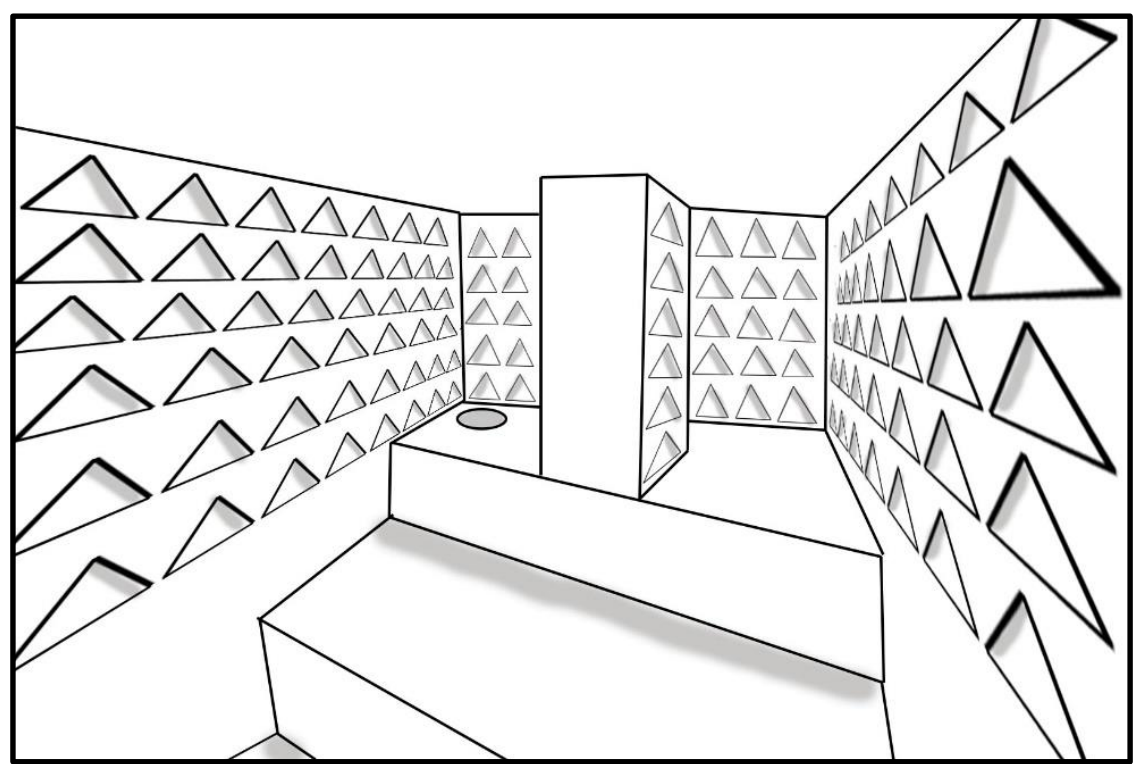

Resim 14: Üçgen Nişli Bir Columbarium Mezarı (Resim 42)

Turkish Studies - Historical Analysis

Volume 14 Issue 3, 2019 


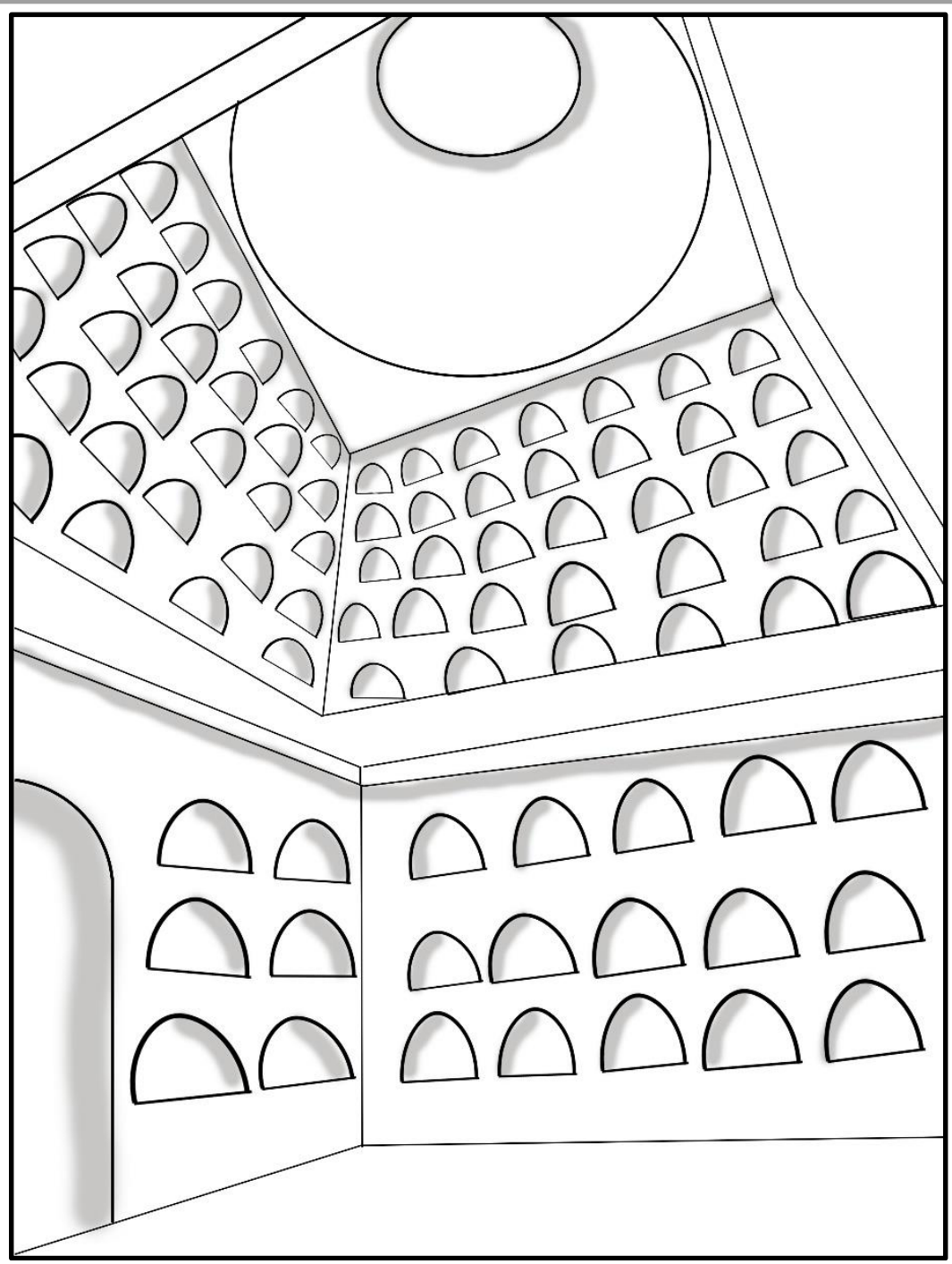

Resim 15: Örnek Bir Columbarium Mezarı (Resim 54)

Koramaz Vadisi columbarium mezarlarında libasyon oluğu da bulunmaktadır (Resim 41). Ortalama $10 \mathrm{~cm}$ çapında olan bu ince ve uzun oluklar, dışarıdan doğrudan columbarium mezarın içine açılmaktadır. Bu bacaların özellikle ölüleri anma günlerinde ölülerin sevdikleri tarafından ölülere sevdikleri şaraptan ikram etmek için kullanıldıkları bilinmektedir (Resim 18), (Borbonus, 2014). Bazı columbarium mezarlarda bu bacalardan iki tane bulunduğu (C2 Columbarium) görülmüştür. 


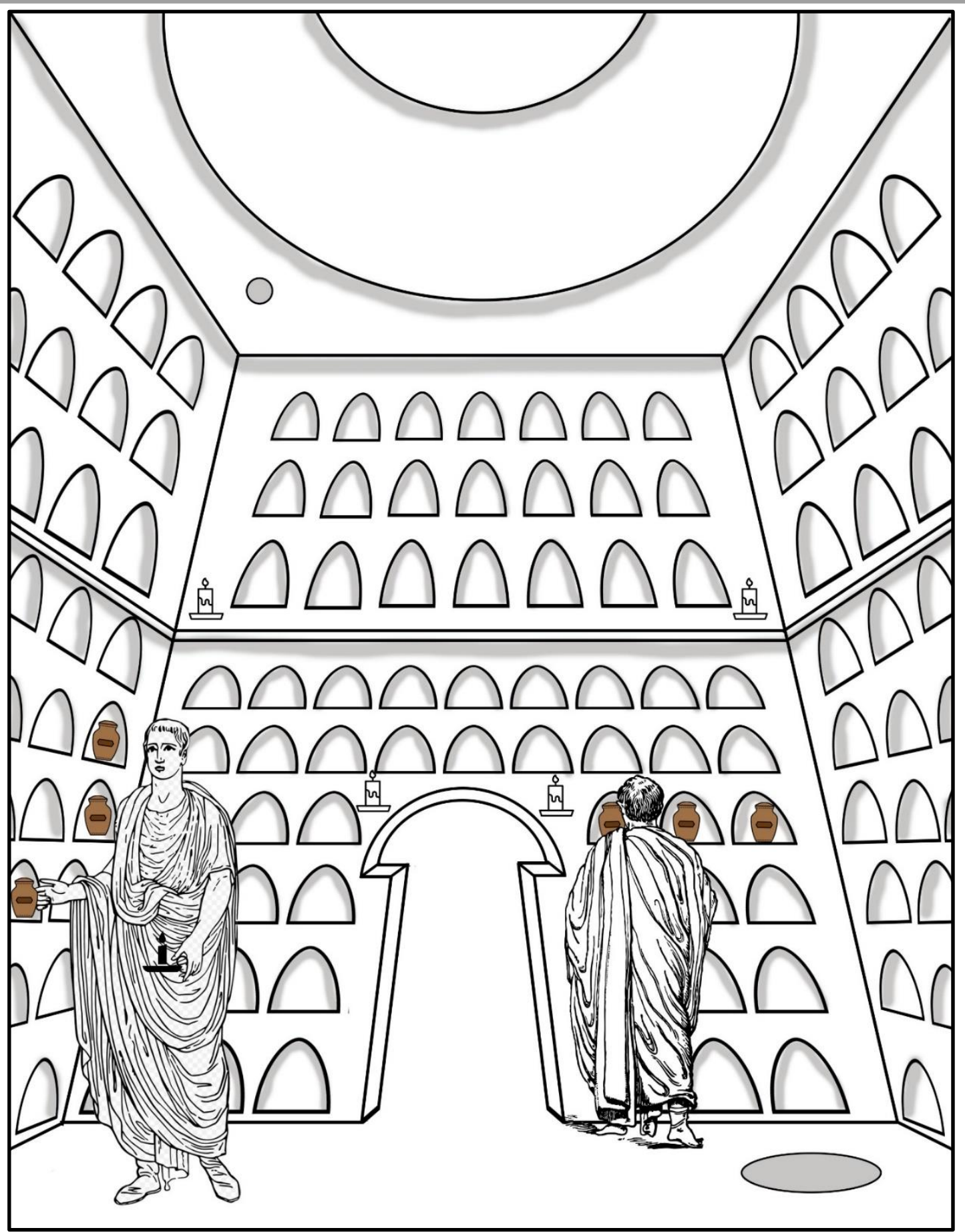

Resim 16: Örnek Bir Columbarium Mezarı İçi 


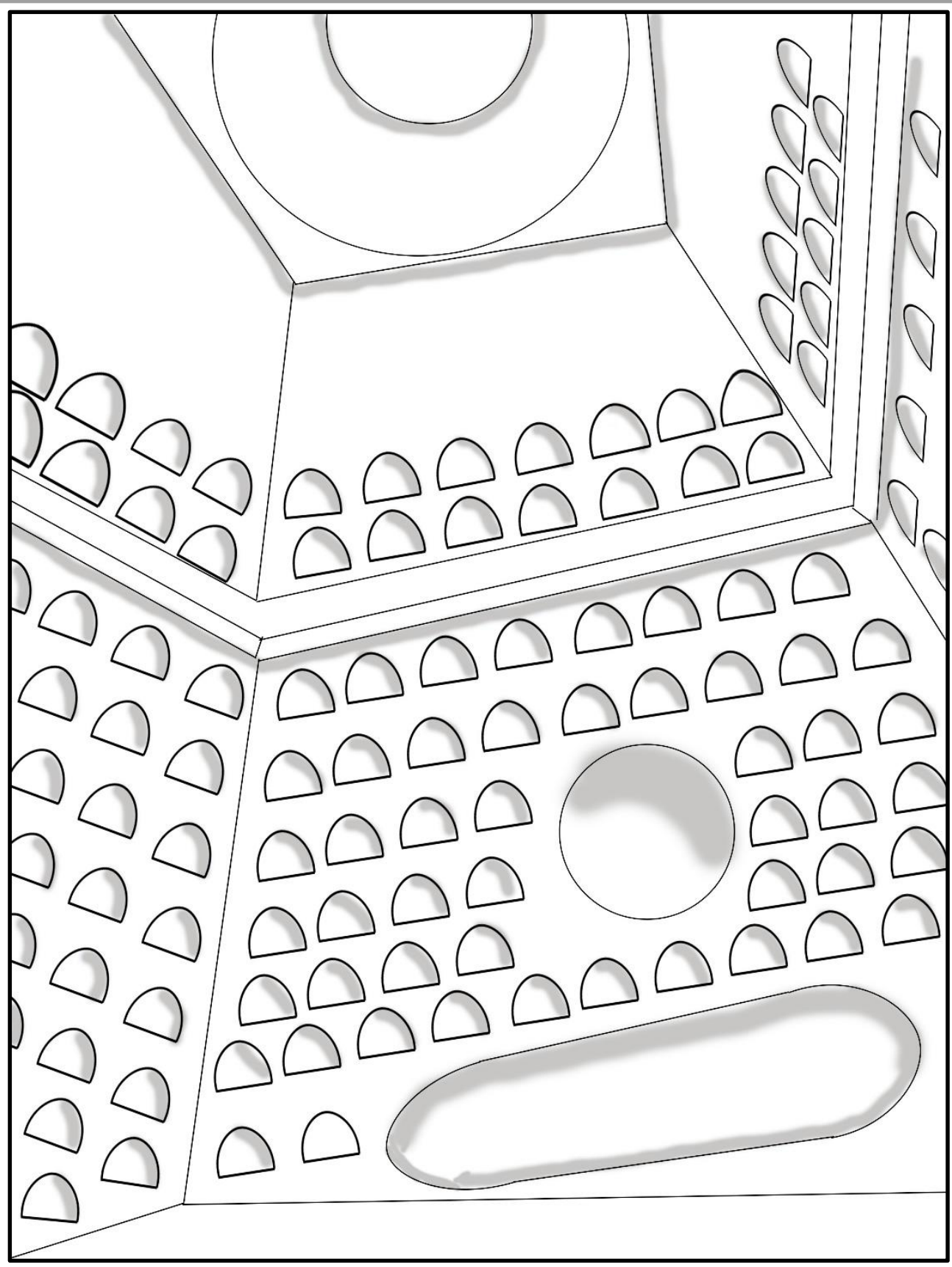

Resim 17: Farklı Türden Nişler Barındıran Bir Columbarium Mezarı (Resim 32)

Çalışmaya konu olan 21 adet columbarium mezarın detaylı ölçüm ve tanılama bilgileri ek 3'de sunulmaktadır. Ancak ortalamalar göz önüne alındığında Koramaz Vadisi'ndeki columbarium mezarların tarifi şöyle yapılabilir: Columbarium mezar odası ortalama zemin ölçüleri " $420 \times 347 \mathrm{~cm}$ " dir. Odaların ortalama yüksekliği $447 \mathrm{~cm}$ 'dir. Her bir columbarium mezar odasında ortalama 144 adet columbarium urne nişi bulunmaktadır. Tüm columbarium mezarlarda silo ve libasyon oluğu bulunmaktadır. Zeminde yer alan siloların kapak çapları ortalama $63,8 \mathrm{~cm}$ olup derinlikleri ortalama $150 \mathrm{~cm}$ 'dir. Giriş kapıları ortalama "106x188(yükseklik) cm" ölçüsündedir. Mezar nişlerinin ortalama genişliği $28,60 \mathrm{~cm}$ olup yükseklikleri $29,55 \mathrm{~cm}$ 'dir. 


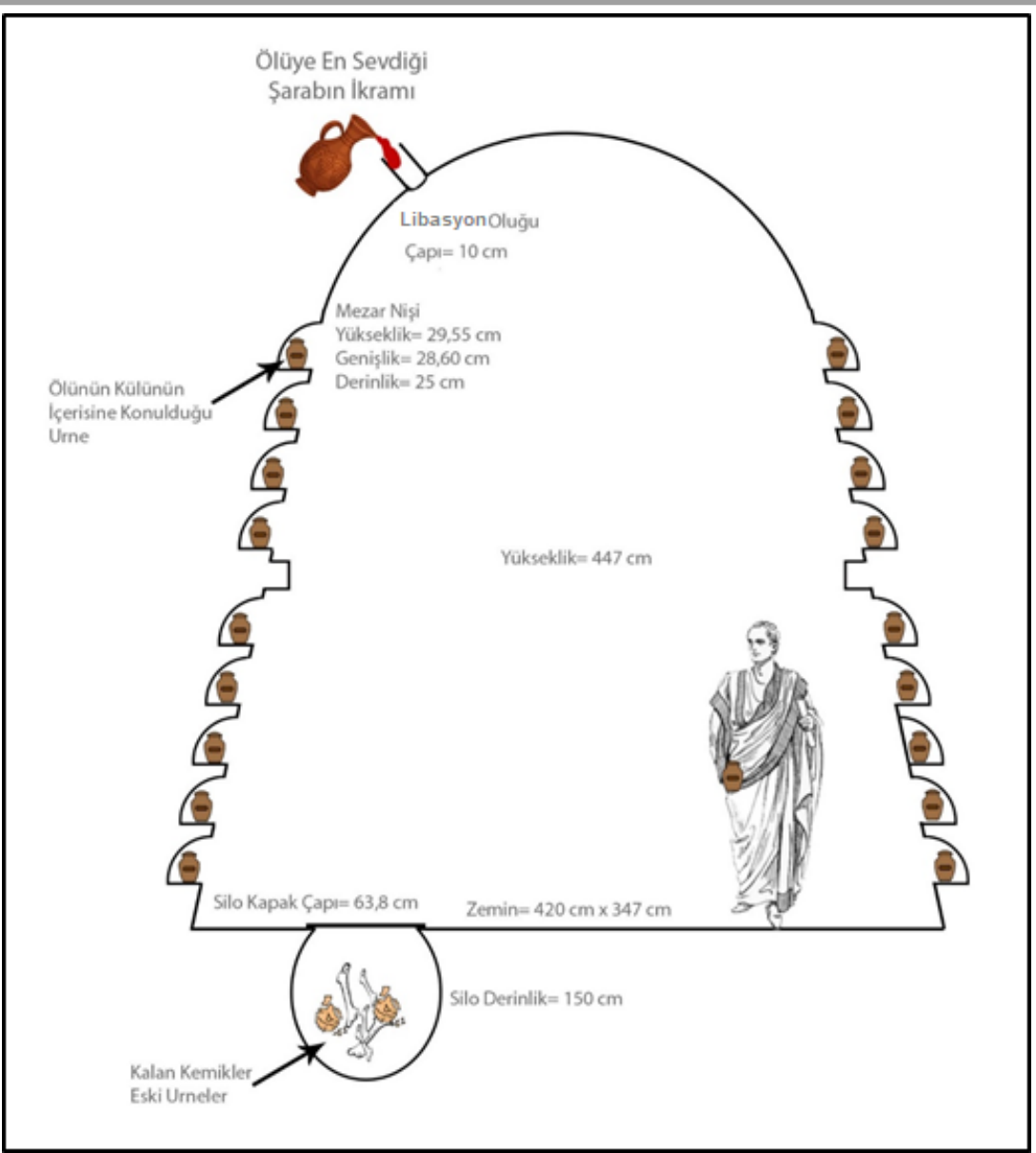

Resim 18: Koramaz Vadisi Columbarium Mezarı Örneği
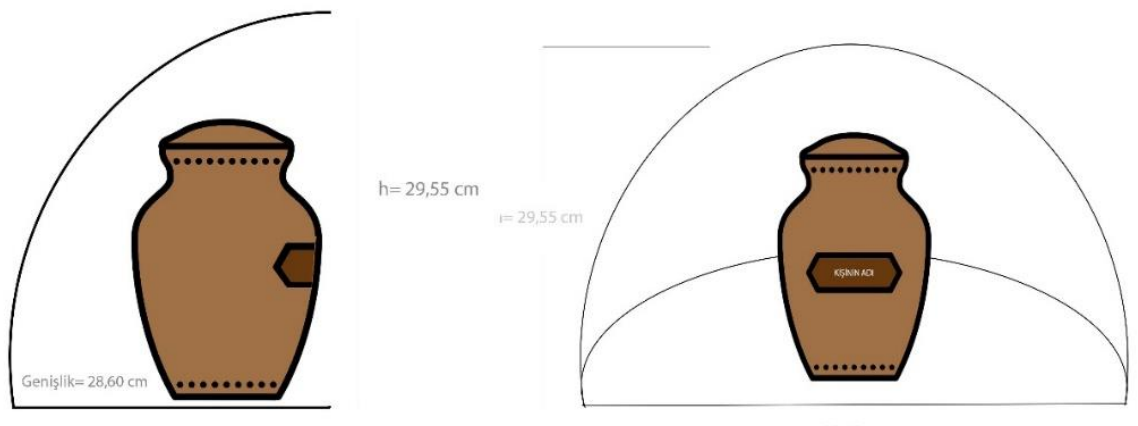

Resim 19: Urne ve Columbarium Urne Nişi

\section{Güvercinlikler ve Columbarium Mezarlar Arasındaki Farklar}

Kayseri'de yüzlerce yıldır güvercin yetiştiriciliği yapıldığı bilinmektedir. Güvercin, yüksek verimli gübresi ile her zaman çiftçiler için değerli olmuştur. Güvercin, Roma'da da Bizans'ta da kutsal bir hayvan olarak görülmüştür. X. yüzyılda Bizans'ta yazılan Geoponica adlı yirmi kitaplık koleksiyonda güvercin yetiştiriciliği diye de bir bölüm bulunmaktadır. Bu bölümde; güvercinliğin nasıl inşa edilmesi gerektiği örnek bir tasarım ile ele alınmakta, özellikle yabani hayvanların erişmesine engel 
olacak bir noktada yapılmasının gerekli olduğu, kapısının çok küçük yapılmasının gerektiği, içerisine nadiren insanın girmesi gerektiği, içerisine güvercinler için su içecek küvetler yapılması gerektiği anlatılmaktadır. Hatta bazı hastalıkların tedavisinde yavru güvercinlerden istifade edildiği yine bu kitapta anlatılmaktadır (Owen, 1806). Büyükmıhçı çalışmasında Gesi bölgesinde yer alan güvercinliklerin daha önce kilise ya da manastır olarak kullanılan yapıların dönüştürülmesi ile yapıldıklarını gözlemlemiştir (Büyükmıhçı, 2006). Yine Büyükmıhçı çalışmasında güvercinlik kapılarının bir insanın rahatça girip çıkabilmesi için oldukça dar olduğunu bildirmektedir. Kayseri'nin önemli bir güherçile üretim merkezi olduğu bilinmektedir. Güvercin gübresinden elde edilen Güherçile adlı kimyasal madde barut yapımında kullanılmıştır. Güherçile Osmanlı için o kadar önemlidir ki Güherçile Nazırlığı kurulmuştur (Hülagü, 2001). Kayseri'nin zaten geçmişten gelen bir columbarium mezar envanterine sahip olması ve bunların kolayca güvercinliğe dönüştürülebilmeleri hiç şüphesiz Kayseri’nin güherçile üretiminde avantaj elde etmesini sağlamıştır.

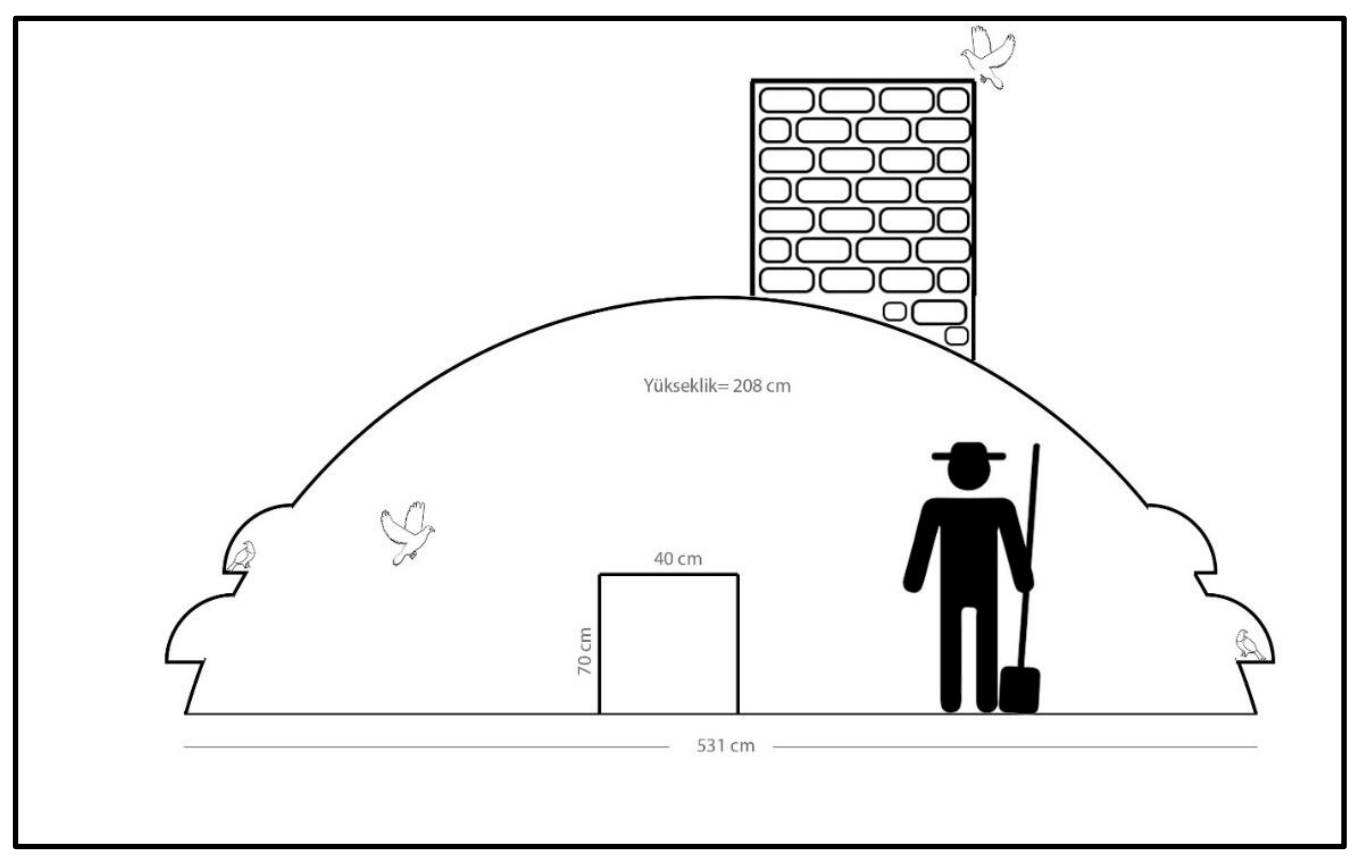

Resim 20: Koramaz Vadisi’nde Bulunan Örnek Bir Güvercinlik

Yukarıda da detayları ile anlatılan gerekçeler ile columbarium mezarların güvercinlikler ile karıştırılması oldukça olasıdır. Koramaz Vadisi'nde orijinal fonksiyon olarak güvercinlik şeklinde inşa edilmiş yapılar da bulunmaktadır ki bu yapılar ile columbarium mezarlar kıyaslandığında bariz farklılıklar göze çarpmaktadır. Güvercinliklerin giriş kapıları yabani hayvanların girmemesi için oldukça küçük yapılmaktadır, bununla beraber güvercinliklerin tavan yükseklikleri columbarium mezarlara kıyasla daha kısadır, ayrıca güvercinlik nişleri çok özensiz bir işçilikle yapılmışlardır. Oysa columbarium mezarların, gösterişli giriş kapıları, görece yüksek tavanları ve ince işçilikle oyulmuş iç mekân ve nişleri bulunmaktadır (Resim 68). Fakat bugün herhangi bir columbarium mezarı incelendiğinde yapı kolayca güvercinlik zannedilebilir zira columbarium mezarların hemen hemen tamamı tavanlarında sonradan açıldığı çok açık görülen, içindeki zarif işçiliği bozarak özensizce kırılarak açıldığı anlaşılan ve merkezde olmayan baca delikleri ile güvercinlik olarak kullanılmışlardır. Columbarium mezarların kapıları ise örülerek daraltılmış güvercinliğe uygun hale getirilmiştir.

Columbarium mezar nişleri güvercinlik nişlerine kıyasla oldukça düzgün biçimde ve dizilimde kazılmışlardır. Ayrıca columbarium mezarların iç mekânları bariz bir biçimde anıtsal mimari anlayışı ile yapılmışlardır. Güvercinliklerde ise doğal olarak yüksek maliyetli işçilikten kaçınılmış ve zaten ihtiyaç da olmadığı üzere özensiz bir iç tasarım ortaya çıkmıştır. Bazı columbarium mezarların 
tavanlarında ve duvarlarında süsleme amaçlı nişler görülmüştür. Bu nişlerin duvarların köşelerinden başlayıp tavanın merkezinde birleştikleri ve itina ile yapıldıkları görülmektedir.

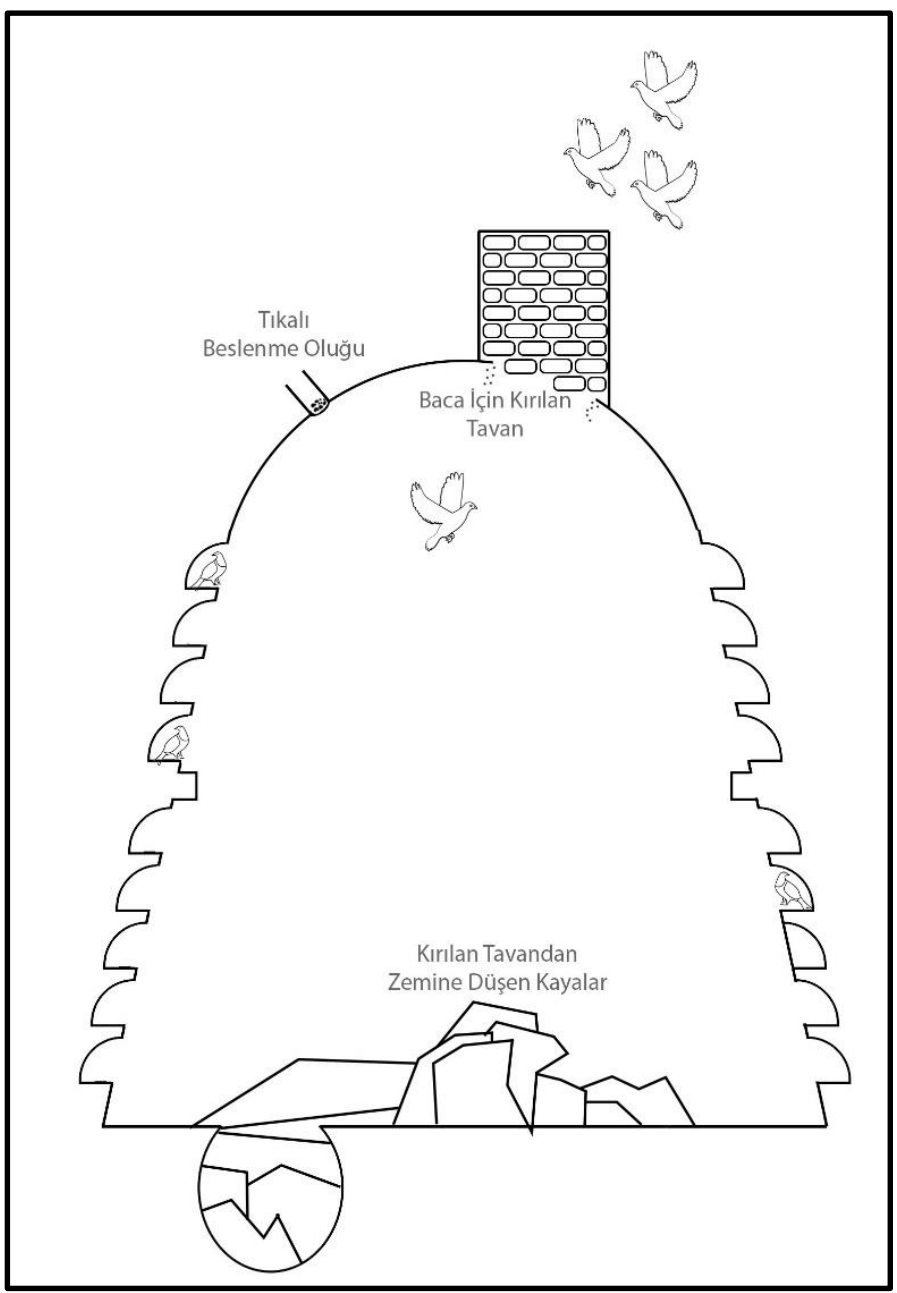

Resim 21: Sonradan Güvercinliğe Dönüştürülen Örnek Bir Columbarium Mezar

Koramaz Vadisi'nde yer alan ve orijinal fonksiyonu güvercinlik olduğu açıkça belli olan üç adet örnek yapı da kıyaslama yapılabilmesi adına bu çalışmada değerlendirilmiştir. Söz konusu üç adet güvercinlik Vekse ve Küçük Bürüngüz köyü sınırları içerisinde yer almaktadır. Bu güvercinliklerin tamamında benzer bir mimari söz konusudur. Tüm güvercinliklerin giriş kapısı oldukça dardır ve ortalama ölçüsü " $42,5 \times 72,5 \mathrm{~cm}$ " dir. Burada dikkat edilirse columbarium mezar kapıları bir insanın rahatça girebileceği ölçülerde inşa edilmiş iken güvercinlik kapısında ancak sürünerek içeri girilebilmektedir, bunun en önemli nedeni yabani hayvanların güvercinlikten uzak tutulmasıdır. Güvercinliklerin ortalama tavan yüksekliğinin $156 \mathrm{~cm}$ olduğu ölçülmüştür, columbarium mezarlarda $447 \mathrm{~cm}$ 'lik bir tavan yüksekliği söz konusudur. Güvercinliklerin her birinde ortalama 50 adet tünek yer almakta iken columbarium mezarlarda bu say1 144 'dür. Güvercinliklerin içi özensiz ve düşük maliyetli bir işçilikle oyulmuştur, tünekler ve iç mimari işin tabiatı gereği oldukça özensizdir. Columbarium mezarlarda güvercinliklerde görülmeyen zemine gömülü silolar çok sayıda bulunmaktadır. Tüm bu hususlar göz önünde bulundurularak ilk fonksiyonu güvercinlik olan bir yapı ile sonradan güvercinliğe dönüştürülmüş columbarium mezar yapısı ayırt edilebilmektedir. 


\section{Sonuç}

Kayseri'nin Erken Tunç Çağı'ndan günümüze kadar sürekli iskân gördüğ̈̈, bir dönem de Roma yönetiminde bulunduğu bilinmektedir. Kayseri şehir merkezinin $20 \mathrm{~km}$ kuzey doğusunda yer alan Koramaz Vadisi $12 \mathrm{~km}$ uzunluğu ve Roma'ya kadar uzanan geçmişi ile Türkiye'nin en önemli vadilerinden birisidir. Bu vadi içerisinde yer alan çok sayıda Bizans Dönemi'ne tarihlenen kaya kilise ve Roma Dönemi'ne tarihlenen kaya mezar bölgenin tarihi derinliğine ve önemine işaret etmektedir. Nitekim vadinin Bizans Dönemi'nde önemli yolların üzerinde bulunduğu da bilinmektedir. Bu çalışmada Koramaz Vadisi'nde yer alan toplam 21 adet columbarium mezarın tespiti ve teknik incelemesi yapılmıştır. Columbarium mezarların zamanla güvercinliğe dönüştürüldükleri bilinmekte ve sıklıkla güvercinlikle karıştırılmaktadırlar, bu çalışmada güvercinlik ile columbarium mezarlar arasındaki farklar da açık bir biçimde ortaya konulmuş ve Koramaz Vadisi columbarium mezarları takdim edilmiştir.

$\mathrm{Bu}$ çalışmaya konu olan yirmi bir adet columbarium mezar detaylı olarak ölçülmüş ve ek 3'de detaylarıyla takdim edilmiştir. Yapılan ölçümlerden elde edilen ortalama veriler 1şığında Koramaz Vadisi'ndeki columbarium mezarları şu şekilde tarif etmek mümkündür: Columbarium mezar odası'nın zemininin ortalama ölçüsü “420x347 cm” dir. Mezar odalarının ortalama yüksekliği 447 cm'dir. Her bir columbarium mezar odasında ortalama 144 adet columbarium urne nişi bulunmaktadır. Columbarium mezarların tamamında silo ve libasyon olukları bulunmaktadır. Zeminde yer alan siloların kapak çapları ortalama $63,8 \mathrm{~cm}$ olup derinlikleri ortalama $150 \mathrm{~cm}$ 'dir. Giriş kapıları ortalama "106x188(yükseklik) cm” ölçüsündedir. Urne nişlerinin ortalama genişliği 28,60 cm olup yükseklikleri 29,55 cm'dir.

Çalışma kapsamında incelenen üç adet güvercinliğin giriş kapılarının ortalama " $42,5 \times 72,5 \mathrm{~cm}$ " olduğu tespit edilmiştir. $\mathrm{Bu}$ giriş kapısı columbarium mezar kapılarına göre oldukça dardır. Güvercinliklerin ortalama tavan yüksekliği $156 \mathrm{~cm}$ 'dir, columbarium mezarlar ile klyaslanacak olursa bu tavan yüksekliği oldukça düşük kalmaktadır. Güvercinliklerin her birinde ortalama 50 adet tünek bulunmasına rağmen columbarium mezarlarda ortalama 144 adet urne nişi yer almaktadır.

Bölgede yapılacak ileri araştırmalar, arkeolojik kazılar bu çalışmada bahsedilen columbarium mezarların geçmişine dair daha net bilgileri sunacaktır. Columbarium mezarların içerisinde bulunacak urne parçaları, kül kalıntıları gibi arkeolojik malzemeler ile bu çalışmadaki iddialar teyit edilebilecek ve tam tarihlendirme yapılması da mümkün olacaktır. Yapılacak ileri araştırmalar ile hem Koramaz Vadisi'nin farklı kesimlerinde hem de Kayseri'deki farklı vadiler içerisinde columbarium mezarların bulunabileceği ön görülmektedir. 
Ek 1. Fotoğraflar

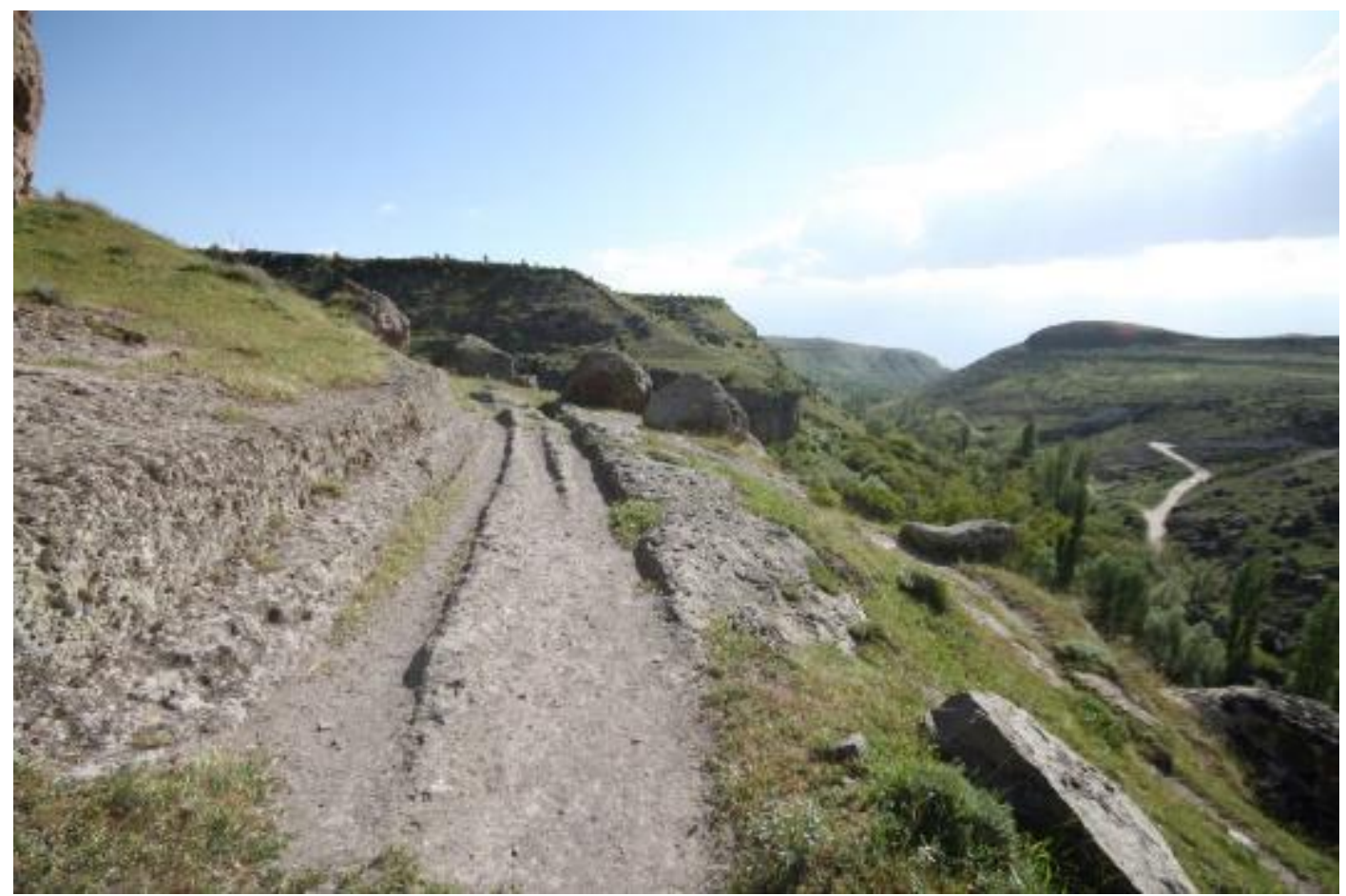

Resim 22: Vadi İçerisinde Sıkça Görülen Kağnı Tekerlerinin Aşındırdığı Yol İzi

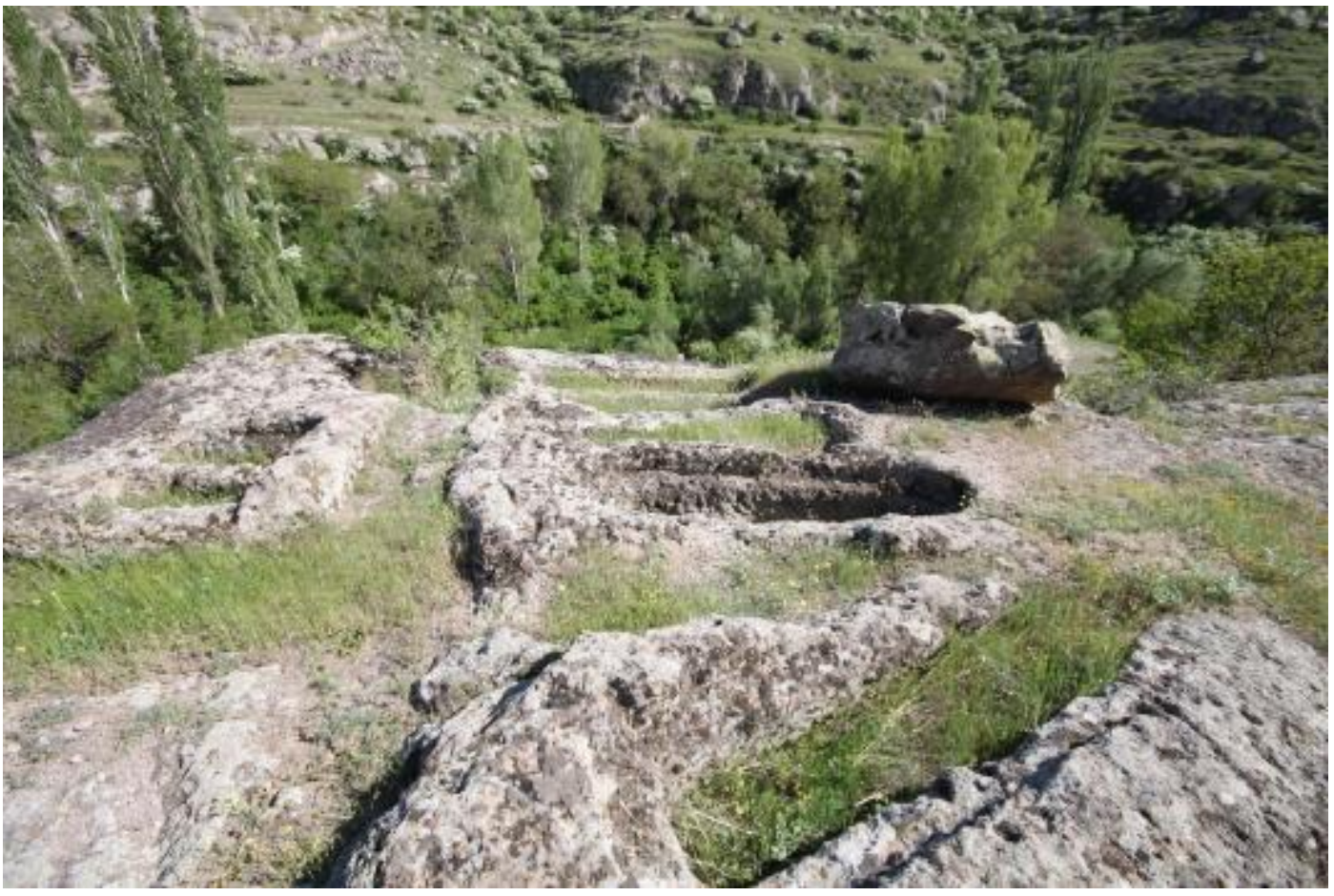

Resim 23: Columbarium Mezarların Yakınında Bulunan Khamosorion Tipi Kaya Mezarlar 


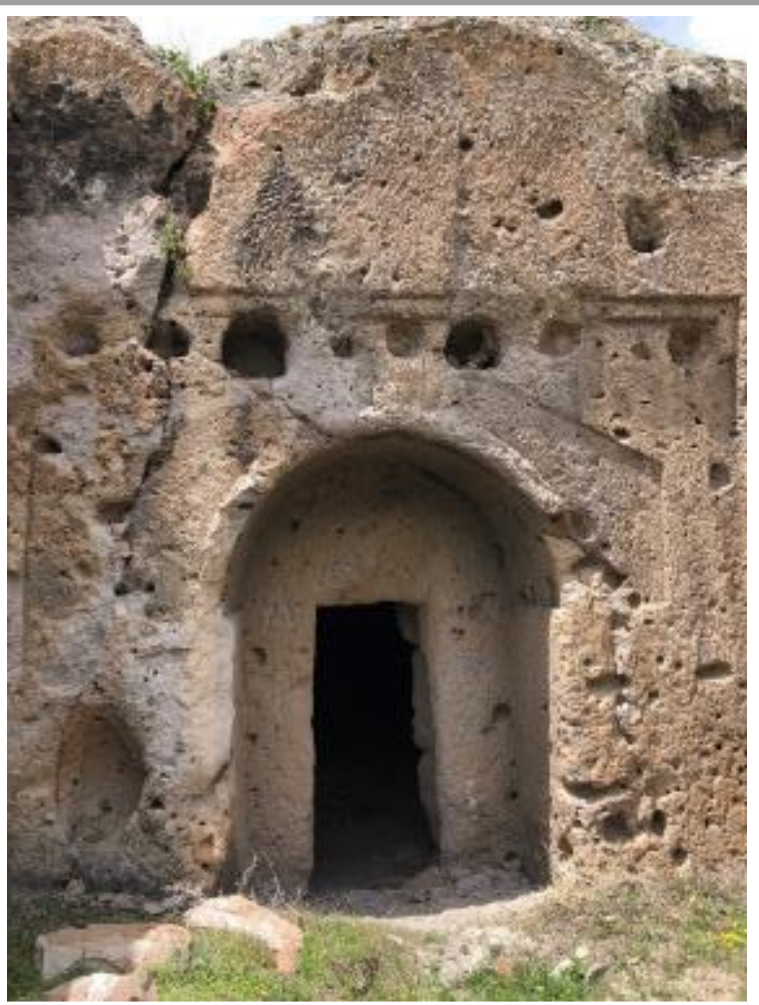

Resim 24: Roma Dönemi’ne Ait Olduğu Düşünülen Anıt Mezar Giriş Kapısı

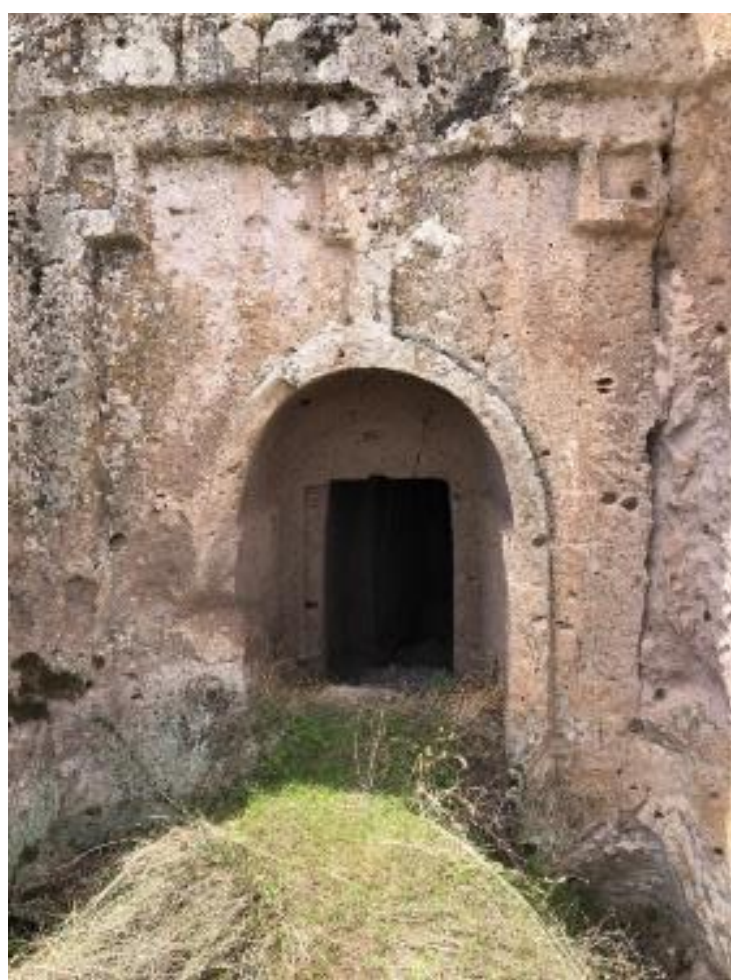

Resim 25: Roma Dönemi’ne Ait Olduğu Düşünülen Anıt Mezar Giriş Kapısı (Sonrada Kiliseye Dönüştürülmüştür)

Turkish Studies - Historical Analysis

Volume 14 Issue 3, 2019 


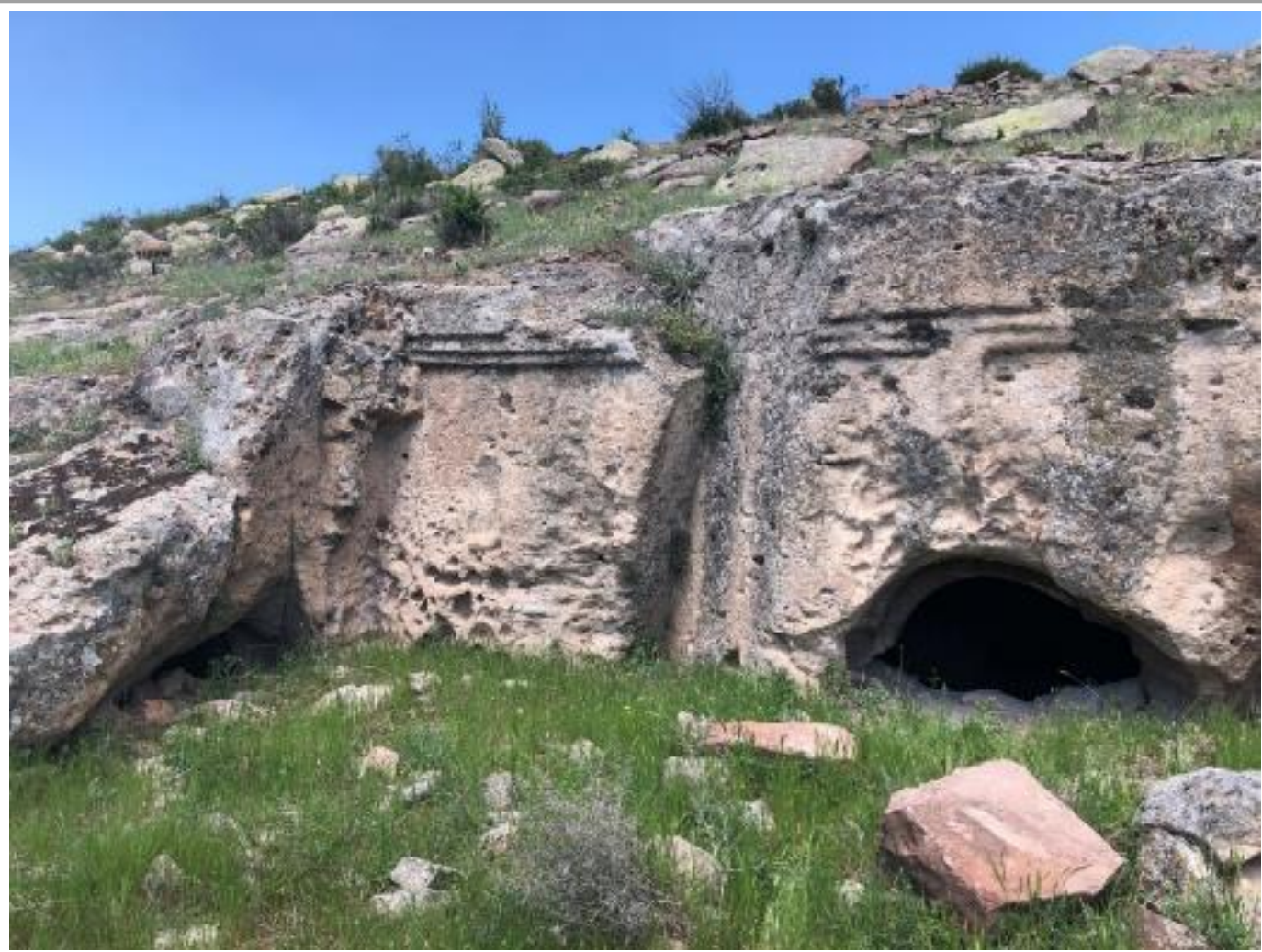

Resim 26: Tipik Bir Koramaz Vadisi Columbarium Mezar Giriș Kapısı

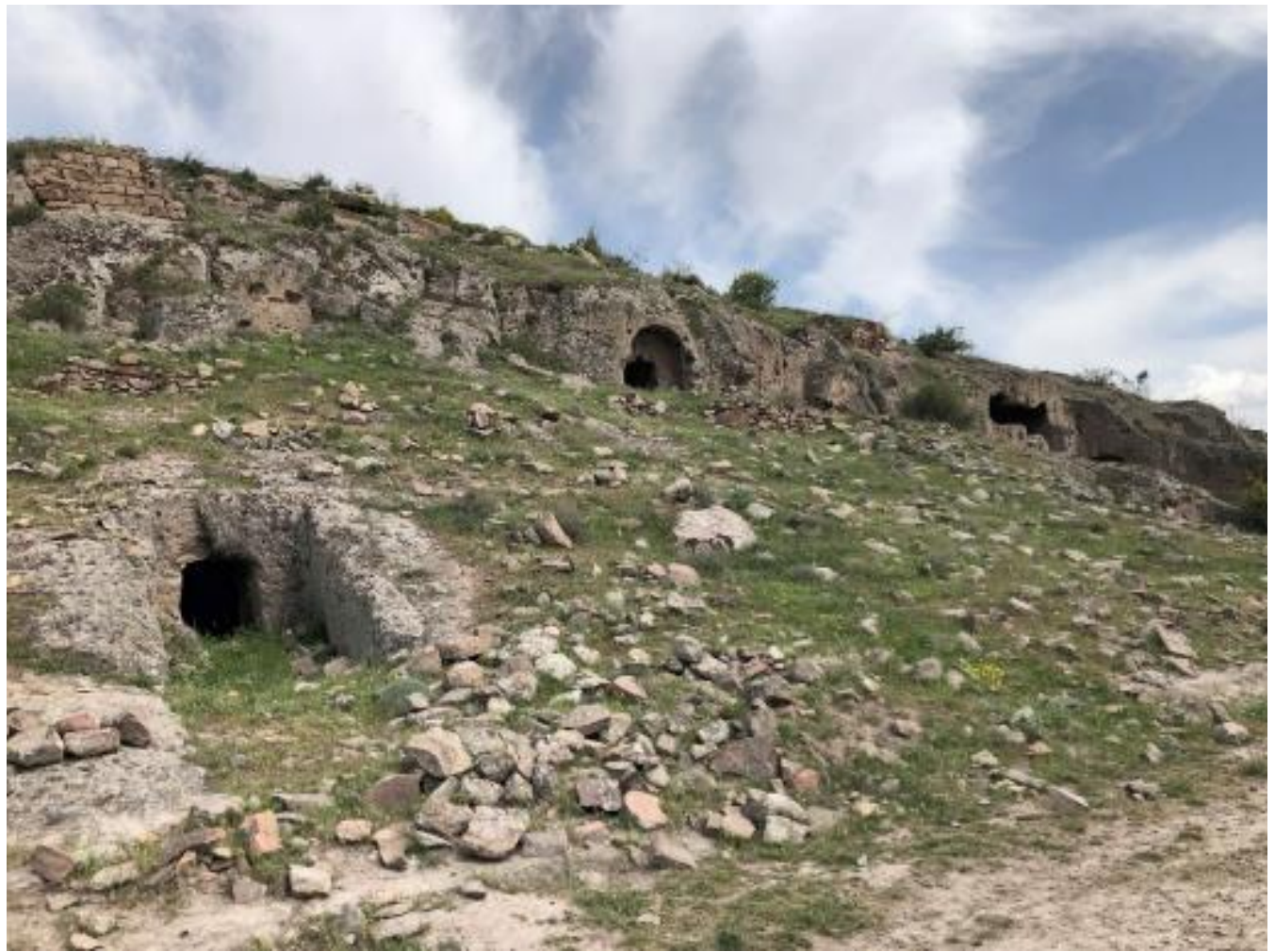

Resim 27: Koramaz Vadisi Columbarium Mezarları Genel Görünüm

Turkish Studies - Historical Analysis

Volume 14 Issue 3, 2019 
AKBIN VADISI KUZEYDOĞU DUVARI 2

Ağırnas, Melikgazi, Kayseri

Çizim: Ezgi Tok (Haziran 2015)

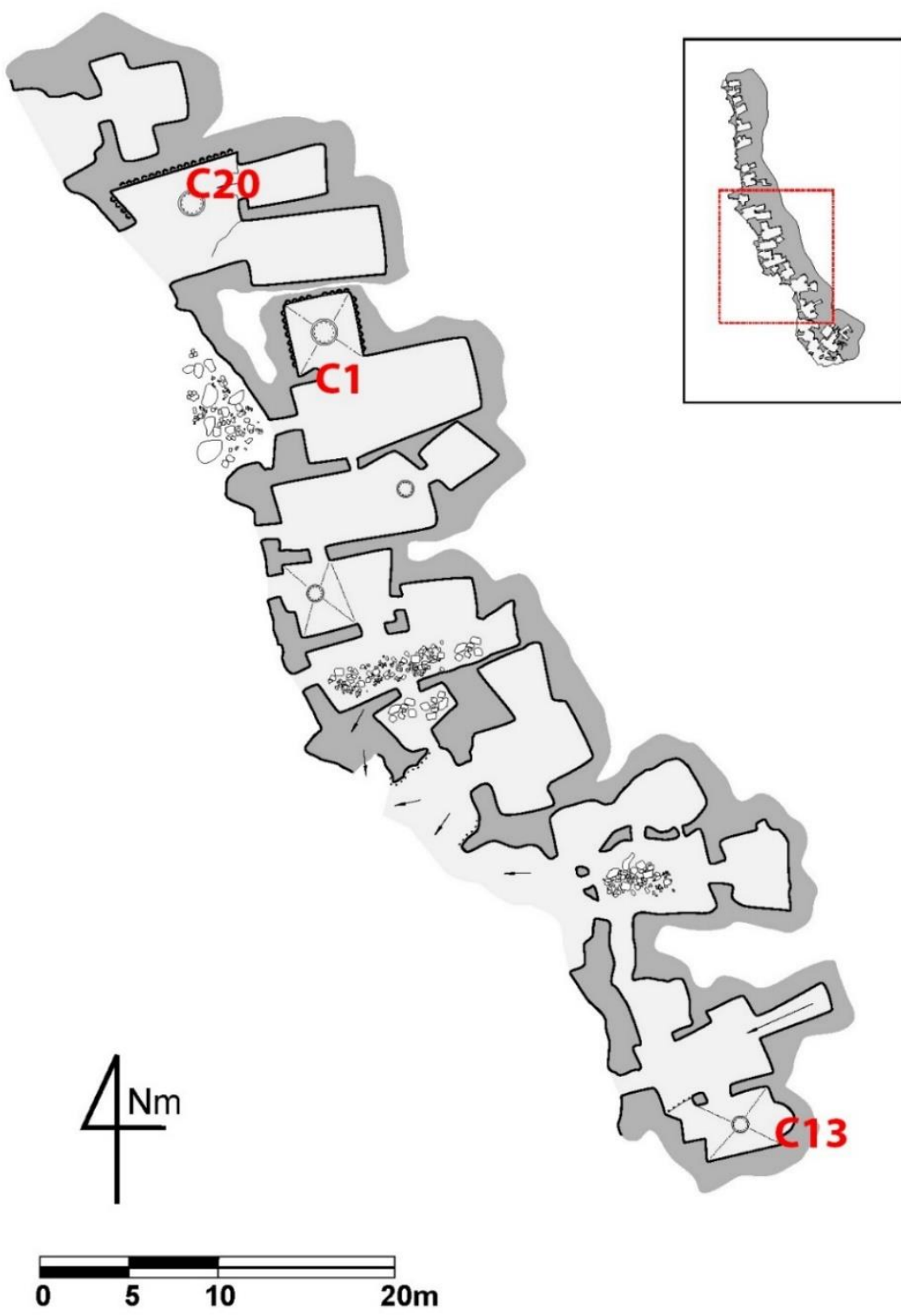

o'mag

Resim 28: Koramaz Vadisi Columbarium Mezarlarının Haritası (1, 13, 20) (Kayseri Yer Altı Yapıları Envanteri, İkinci Ara Rapor (2015)) 


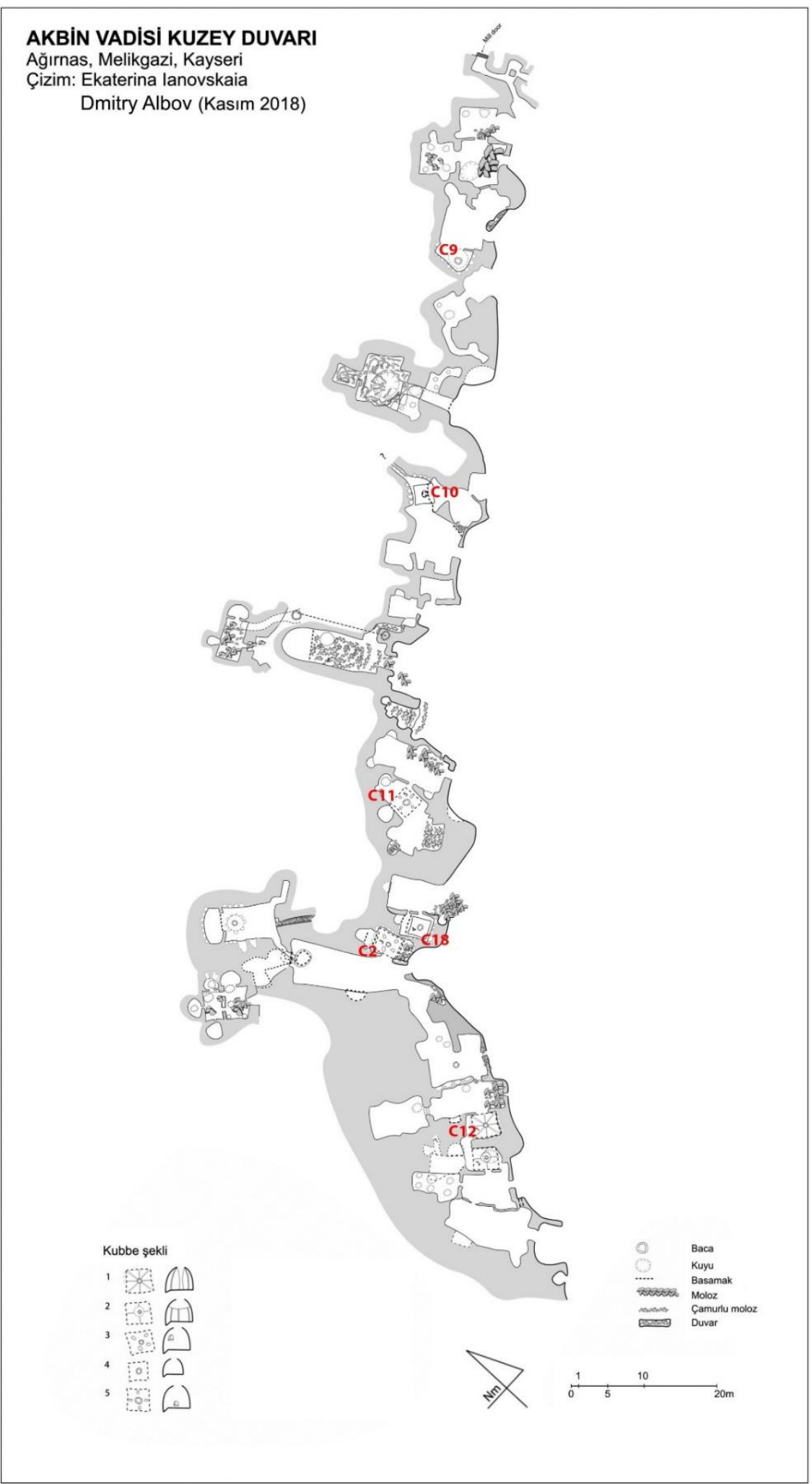

Resim 29: Koramaz Vadisi Columbarium Mezarlarının Haritası $(2,9,10,11,12,18)$ (Kayseri Yer Altı Yapıları Envanteri, İkinci Ara Rapor (2015))

Turkish Studies - Historical Analysis

Volume 14 Issue 3, 2019 


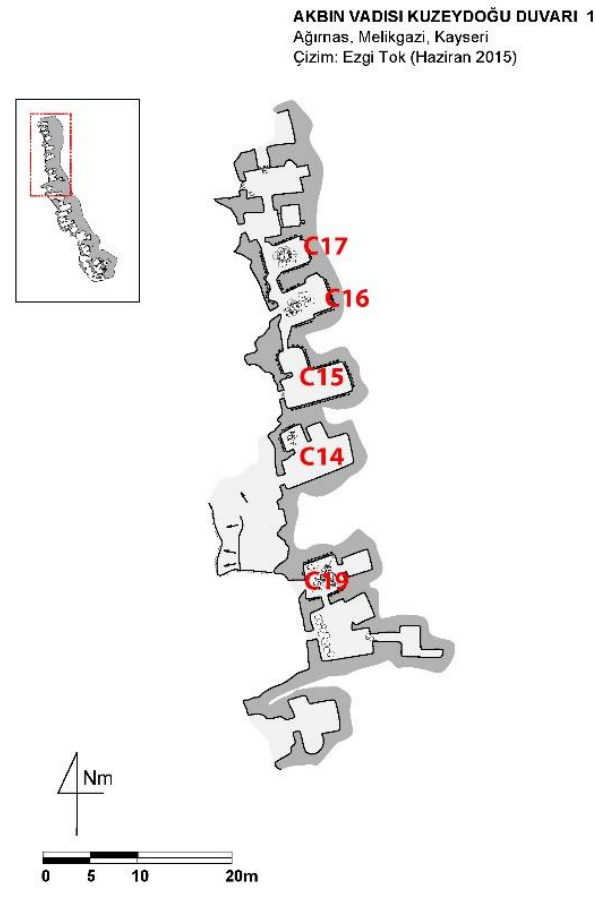

Resim 30: Koramaz Vadisi Columbarium Mezarlarının Haritası (14, 15, 16, 17, 19) (Kayseri Yer Altı Yapıları Envanteri, İkinci Ara Rapor (2015))

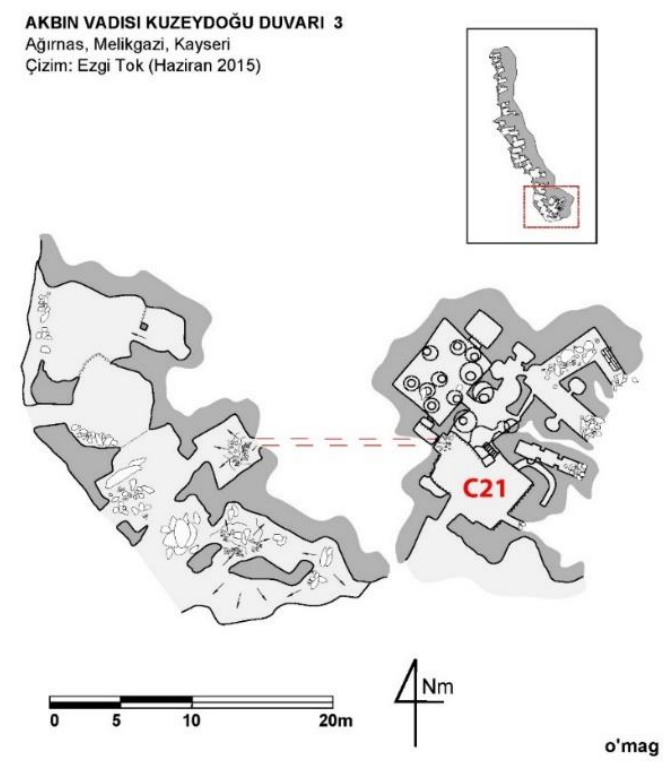

Resim 31: Koramaz Vadisi Columbarium Mezarları Haritası (21) (Kayseri Yer Altı Yapıları Envanteri, İkinci Ara Rapor (2015)) 


\section{Ek 3. Koramaz Vadisi Columbarium Mezarları}

Kodu

C1

Konumu

Açıklamalar
Akbin Deresi, Öküz İni Mevkii

Yapı, vadi yamacının yumuşak tüf kayaları içerisine girilecek şekilde oyulmuştur. Giriş kapısı yol çalışmaları esnasında çökmüş yapının, mevcut giriş kapısı aslında bir iç oda kapısıdır. $100 \mathrm{~cm}$ genişliğinde ve $212 \mathrm{~cm}$ yüksekliğindeki giriş kapısının çevresinde süslemeler göze çarpmaktadır, kapı batıya bakmaktadır. Bu kapının ardında dikdörtgen planlı, "1030x383 cm" ölçülerinde tavanı ișlemeli ve duvarları az sayıda urne niși barındıran bir oda bulunmaktadır. Bu oda sonradan ahır olarak kullanılmak maksadı ile yakın zamanda genişletilmiştir. Giriş kapısından içeri girdikten sonra hemen sağda giriş kapısı ölçülerinde, yukarısı yarım daire şeklinde olan dikdörtgen ve bir kısmı kırılmış bir kapı bulunmaktadır. Bu kapı zemini " $393 \times 571 \mathrm{~cm}$ ” ölçülerinde kubbesel mimariye sahip bir columbarium mezar odasına açılmaktadır. Duvarlarında 200 civarında urne nişi yer almaktadır, bu nişler oldukça yıpranmış durumdadır, genel olarak üçgen ya da yarım daire formunda kazılmışlardır ve ortalama "20x20 cm" ölçülerindedirler. Bazı nişlerin zaman içerisinde birleştirilerek dikdörtgen ya da oval şeklinde büyütüldüğü görülmektedir. $\mathrm{Bu}$ alanların ölülerden kalan eşyaların, kemiklerin ya da ölülere getirilen hediyelerin saklandığı alanlar olduğu ön görülebilir. Zeminden yukarıya doğru daralan bir yapıya sahip olan bu yapının tavanı kubbe şeklindedir. Kubbenin görece daha işçilikli yapılmış olduğu ve kıyasla pürüzsüz bir zemine sahip olduğu görülmektedir. Zeminden tavana doğru ilerlerken yapıyı yatayda ikiye bölen $10 \mathrm{~cm}$ kalınlığında bir niş göze çarpmaktadır. Tavan yüksekliği $571 \mathrm{~cm}$ olup tavanda merkezde olmayan, kırılma usulü ile açılmıș olan $70 \mathrm{~cm}$ civarından bir baca deliği bulunmaktadır. Baca deliğinin zeminin yukarısında yer alan kısmı ise sonradan taşlarla örülerek baca haline getirilmiştir. Bu baca deliklerine bölgedeki tüm columbarium mezar yapılarında rastlanmaktadır. Bacaların merkezde olmaması, düzensiz bir biçimde kırılarak açılmış olması bu bacaların sonradan açıldıklarına işaret etmektedir. Yapının zemininde yaklaşık $60 \mathrm{~cm}$ kapak ağız genişliğine sahip bir yer altı deposu (silo) bulunmaktadır, buranın yaklaşık $120 \mathrm{~cm}$ civarında bir derinliğe sahip olduğu düşünülmektedir (şu an dibi toprak ile dolu durumdadır). $\mathrm{Bu}$ depoların yanmamış insan kemiklerinin ve atıl hale gelmiş kül kaplarının depolanması maksadı ile kullanıldığı tahmin edilmektedir. Yapı içerisinde irili ufaklı çok sayıda seramik parçası görülebilmektedir. Bu yapının kuzey duvarının bitişiğinde bir dikdörtgen oda daha bulunmaktadır. Bu odada üçgen şeklinde mezar nişleri yer almaktadır. Yapı şu anda hayvan barınağı olarak kullanılmaktadır. Bu yapının birkaç odadan oluşan bir columbarium mezar olduğu açıktır.

Turkish Studies - Historical Analysis

Volume 14 Issue 3, 2019 


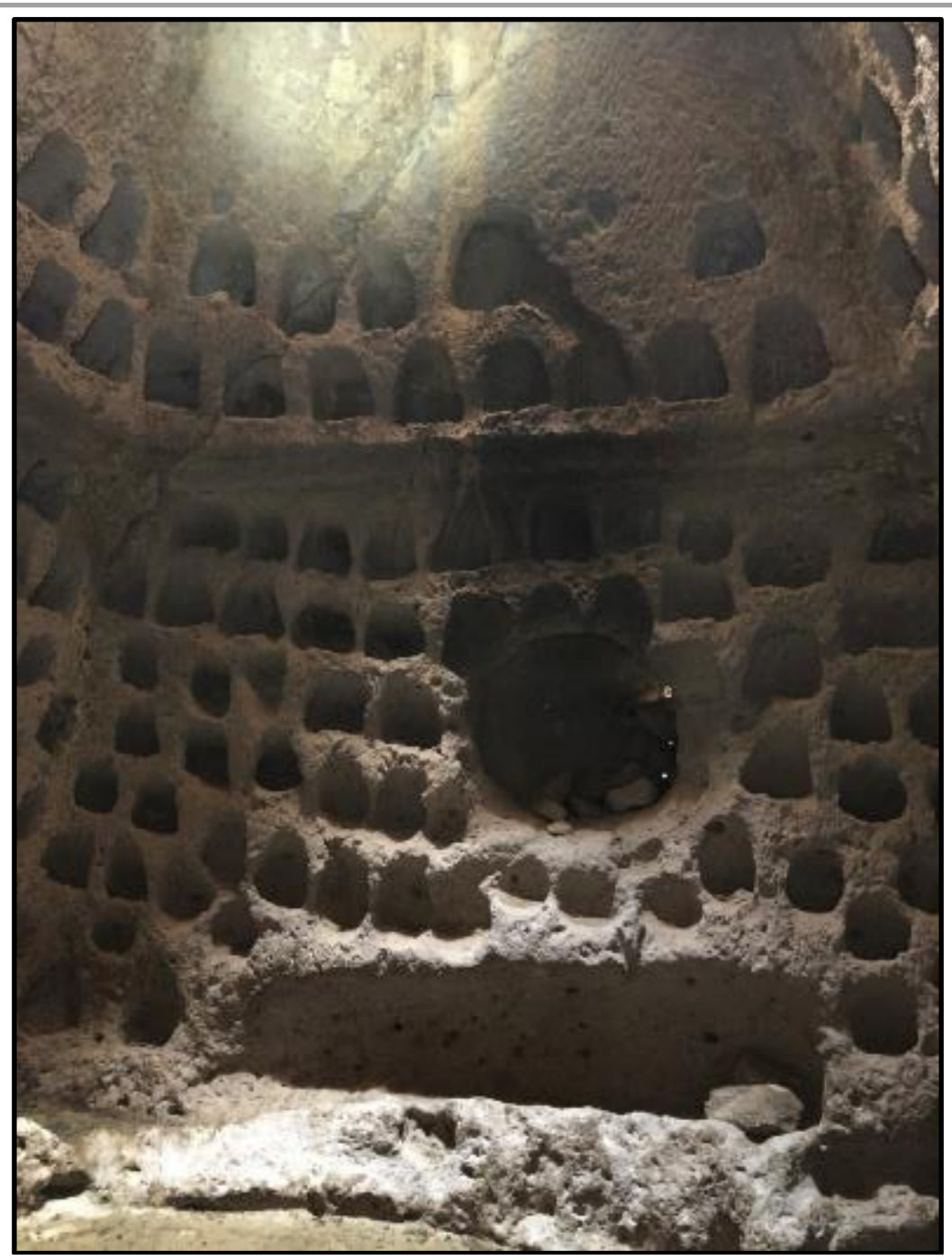

Resim 32: C1 Columbarium Mezarı İçi

\section{Kodu C2}

Konumu Akbin Deresi, Öküz İni Mevkii

Açıklama

Yapı, vadi yamacının yumuşak tüf kayaları içerisine girilecek şekilde oyulmuştur. Giriş kapısı yol çalışmaları esnasında çökmüş yapının, mevcut giriş kapısı aslında bir iç oda kapısıdır. $104 \mathrm{~cm}$ genişliğinde ve $178 \mathrm{~cm}$ yüksekliğindeki giriş kapısının çevresinde süslemeler ve rastgele oyulmuş mezar nişleri göze çarpmaktadır, kapı güneye bakmaktadır. Bu kapının ardında dikdörtgen planlı, yaklaşık "1460x450 cm" ölçülerinde bir oda bulunmaktadır. Giriş kapısından içeri girdikten sonra hemen sağda giriş kapısı ölçülerinde, yukarısı yarım daire şeklinde olan dikdörtgen bir kapı bulunmaktadır. Bu kapı zemini "305x290 cm" ölçülerinde kubbesel mimariye sahip bir columbarium mezar odasına açılmaktadır. Duvarlarında 70 civarında urne nişi yer almaktadır, bu nişler genel olarak düzgün üçgen formunda kazılmışlardır ve ortalama " $28 \times 24 \mathrm{~cm}$ " ölçülerindedirler. Odanın iki duvarının yaklaşık 1 metre derinliğinde yarım daire şeklinde genişletildiği görülmektedir, bu girinti içerisinde yine çok sayıda urne nişi yer almaktadır, ayrıca nişler içerisinde bir tane de "120x120 cm" ölçülerinde geniş bir niş yer almaktadır. Zeminden

\section{Turkish Studies - Historical Analysis}

Volume 14 Issue 3, 2019 
yukarıya doğru daralan bir yapıya sahip olan bu yapının tavanı kubbe şeklindedir. Kubbenin görece daha işçilikli yapılmış olduğu, simetrik toplam dört adet " $40 x 60 \mathrm{~cm}$ " ölçülerinde niş barındırdığı ve kıyasla pürüzsüz bir zemine sahip olduğu görülmektedir. Zeminden tavana doğru ilerlerken yapıyı yatayda ikiye bölen, zeminden $287 \mathrm{~cm}$ yukarıda yer alan ve $10 \mathrm{~cm}$ kalınlığında bir niş göze çarpmaktadır. Tavan yüksekliği $497 \mathrm{~cm}$ olup tavanda merkezde olmayan, kırılma usulü ile açılmış olan $70 \mathrm{~cm}$ çapında bir baca deliği bulunmaktadır. Yapı içerisinde bir zemin deposu bulunamamıştır, zemin yıkılmış kaya parçaları dile doludur. Yapı içerisinde irili ufaklı çok sayıda seramik parçası görülebilmektedir. Yapının tavan bölümünde $10 \mathrm{~cm}$ ve $20 \mathrm{~cm}$ çapında iki adet dışa bağlantı sağlayan libasyon oluğu bulunmaktadır. Bu bacaların columbarium mezar odası içerisine şarap akıtmak için kullanıldığı tahmin edilmektedir.

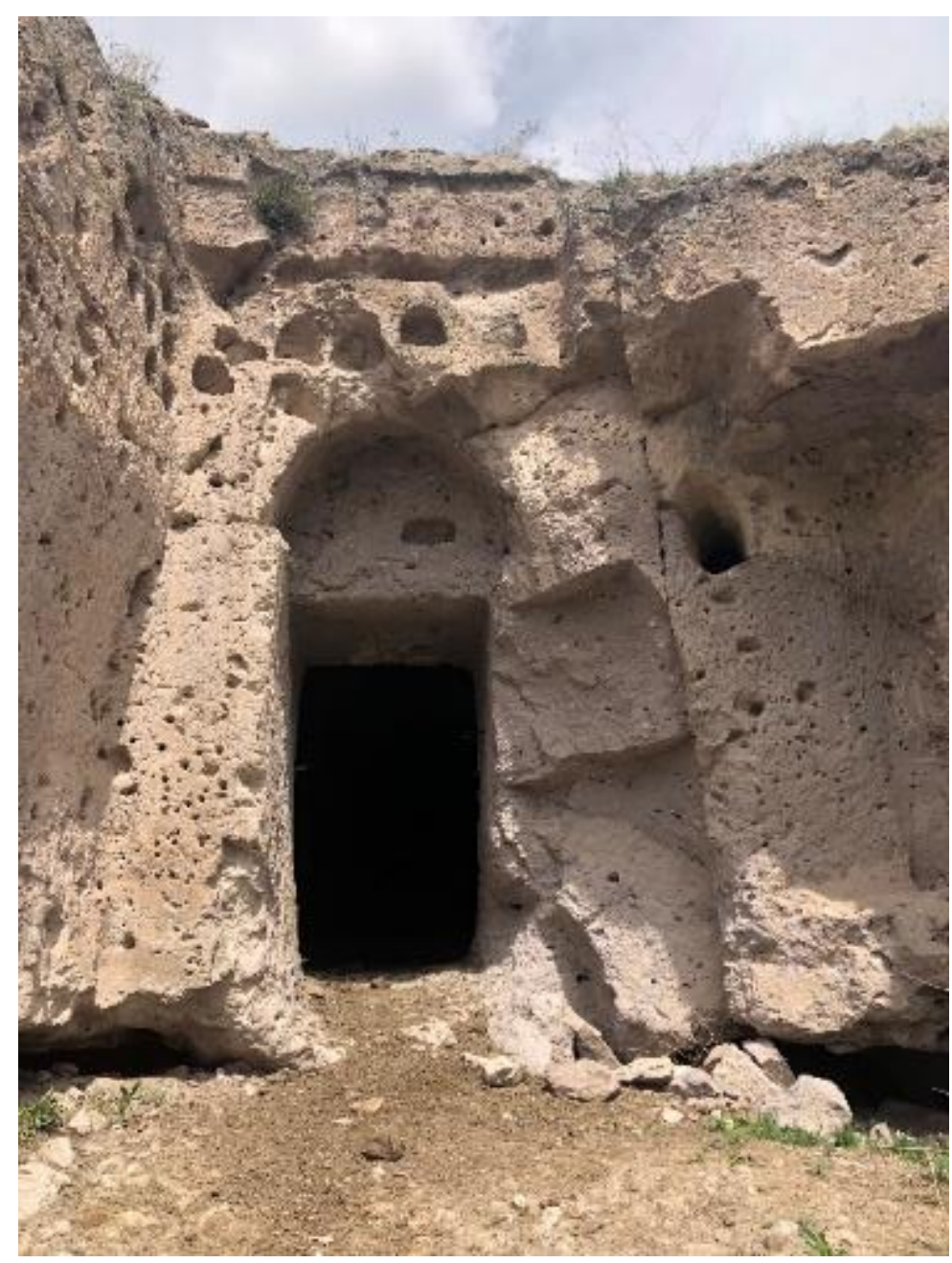

Resim 33: C2 Columbarium Mezarı Giriş Kapısı 


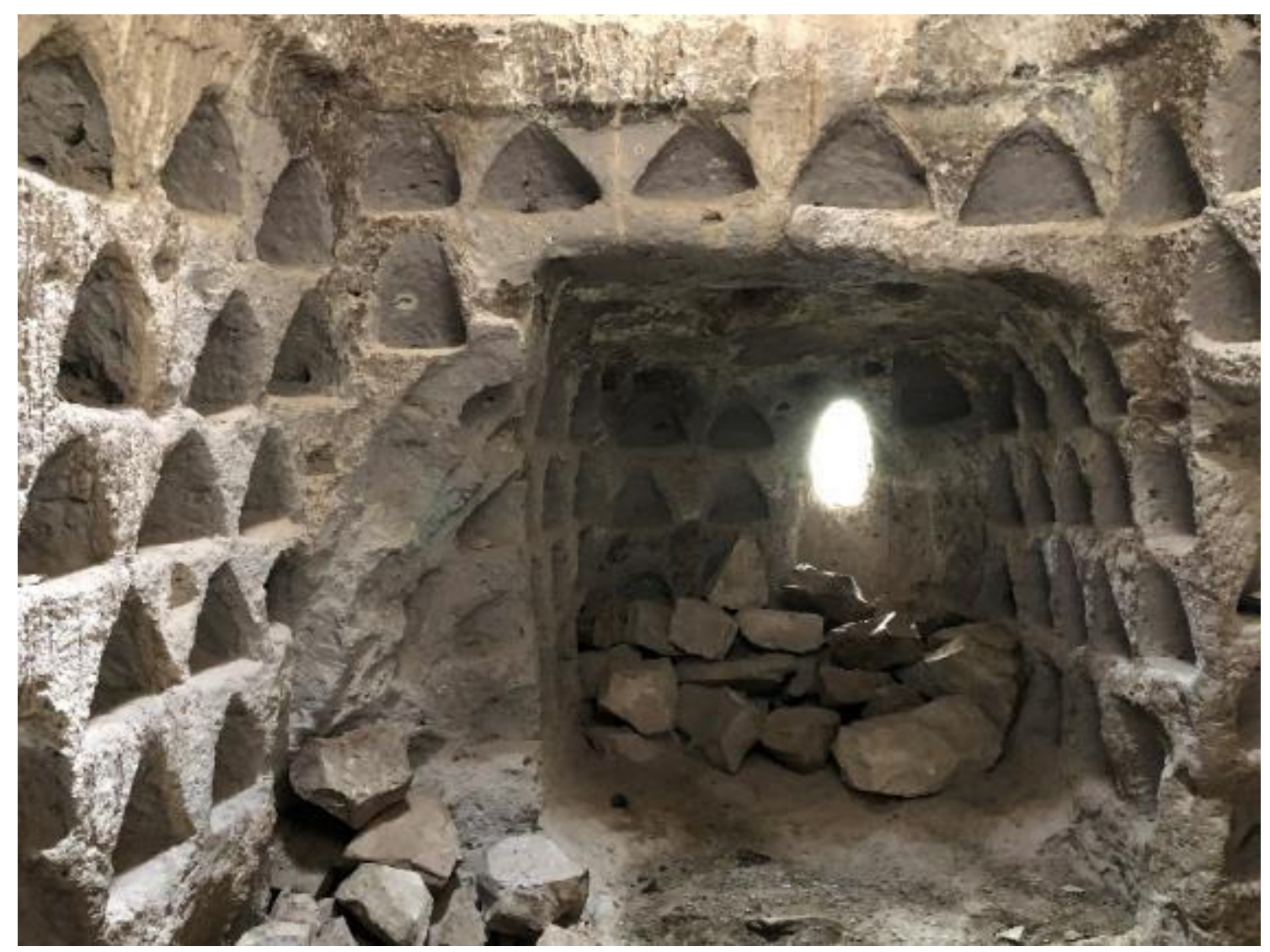

Resim 34: C2 Columbarium Mezarı İçi

Kodu

Konumu

Açıklama
C3

Akbin Deresi, Öküz İni Mevkii Güneyi

Yap1, vadi yamacının yumuşak tüf kayaları içerisine girilecek şekilde oyulmuştur. Yapının giriş kapısı toprak altındadır, tavana yakın bir bölgesi çökmüştür ve buradan yapıya girilmektedir. Yapının kapısı kuzeye bakmakta olup, toprak altından göründüğü kadarı ile çevresi işlemeli bir kapıdır. Yapı " $895 \times 361$ cm" ölçülerinde dikdörtgen planlı bir oda şeklinde kazılmıştır. Yapının güney duvarı bölgesinde dikdörtgen bir girinti yer almaktadır. Girintinin tabanı sonradan havuz şeklinde oyulmuştur. Yapı incelendiğinde bu havuzun bir kanalla daha küçük bir havuza dar bir kanal ile bağlandığı görülmektedir. Başta columbarium mezar olarak kullanılan yapının sonradan şıra haneye dönüştürüldüğü sonradan yapılan havuzlardan anlaşılmaktadır. Duvarlarında 75 civarında urne nişi yer almaktadır, bu nişler oldukça yıpranmış durumdadır, genel olarak yıpranmış kare ve yarım daire formunda kazılmışlardır ve ortalama " $30 \times 25 \mathrm{~cm}$ " ölçülerindedirler. Yapı içerisinde yerden $50 \mathrm{~cm}$ yükseklikte duvarda "180x30 cm" genişliğinde büyük bir niş daha görülmektedir. Yapıda $100 \mathrm{~cm}$ çapında bir baca kırığı bulunmaktadır. Yapı içerisinde bir zemin deposu bulunamamıştır, zemin yıkılmış kaya parçaları dile doludur. Yapı içerisinde irili ufaklı çok sayıda seramik parçası görülebilmektedir. Yapının tavan yüksekliği 310 cm'dir. 


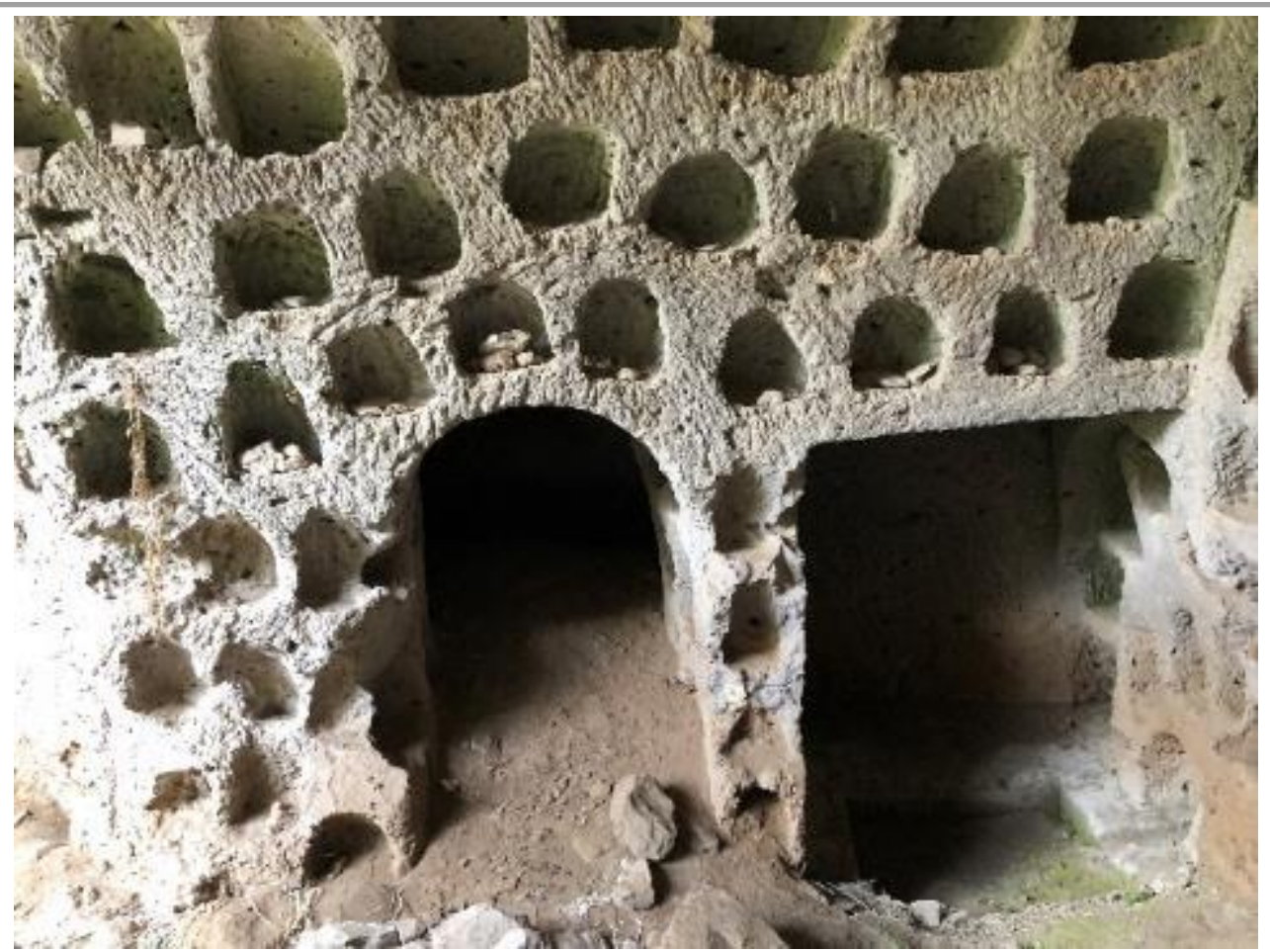

Resim 35: C3 Columbarium Mezarı İçi

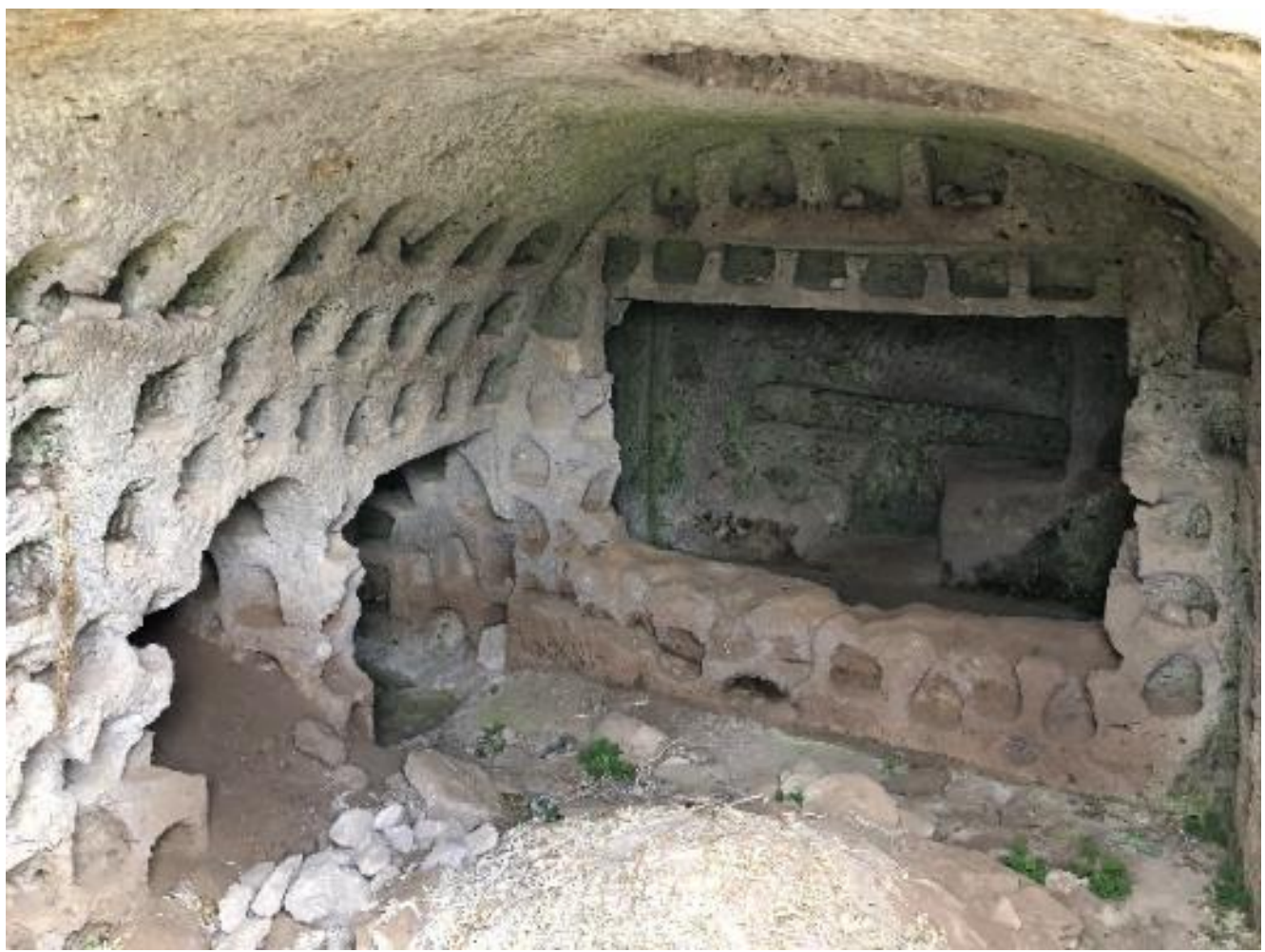

Resim 36: C3 Columbarium Mezarı İçi 


\begin{tabular}{|c|c|}
\hline Kodu & $\mathbf{C 4}$ \\
\hline Konumu & Akbin Deresi, Öküz İni Mevkii Güneyi \\
\hline Açıklama & 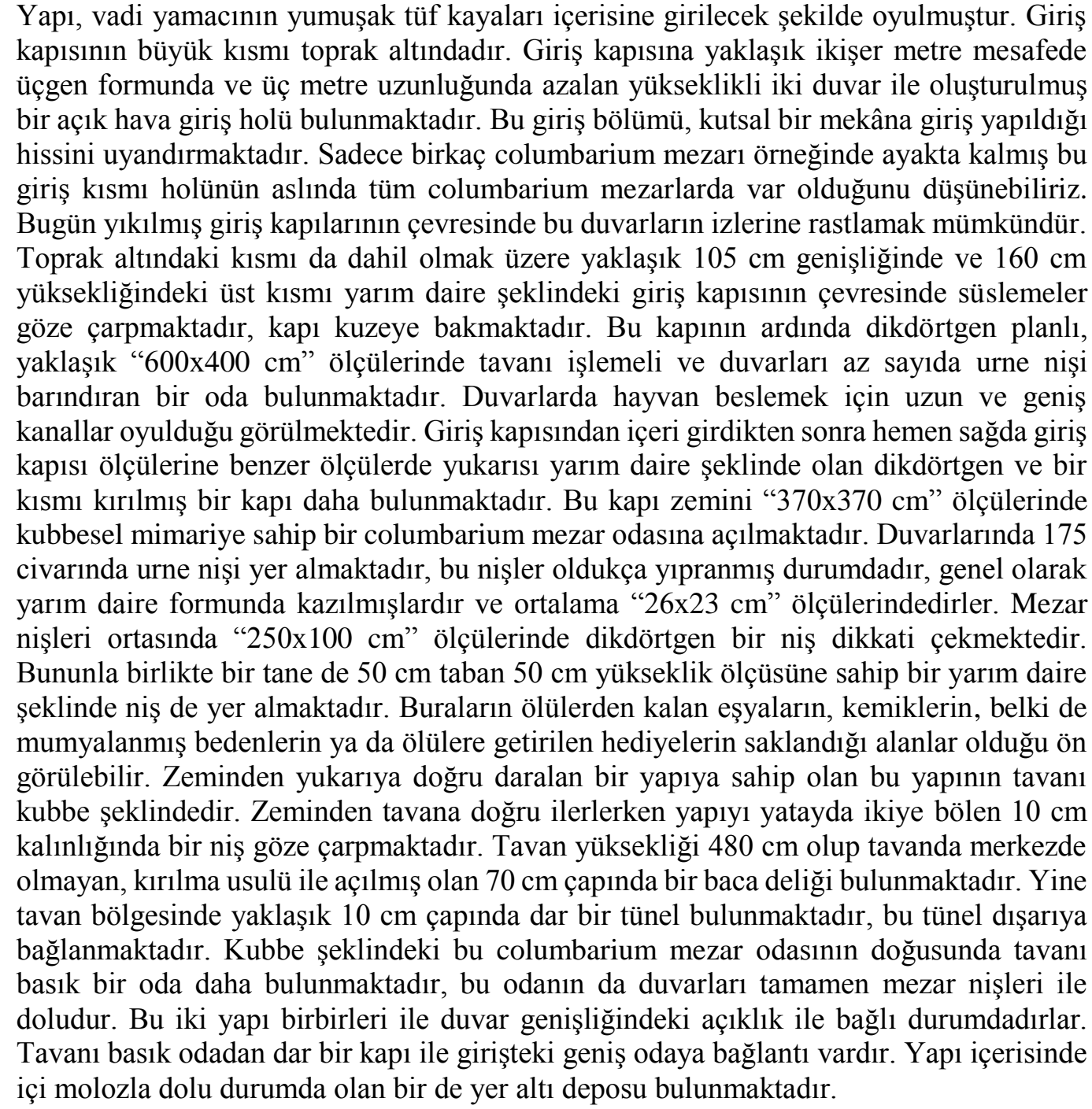 \\
\hline
\end{tabular}




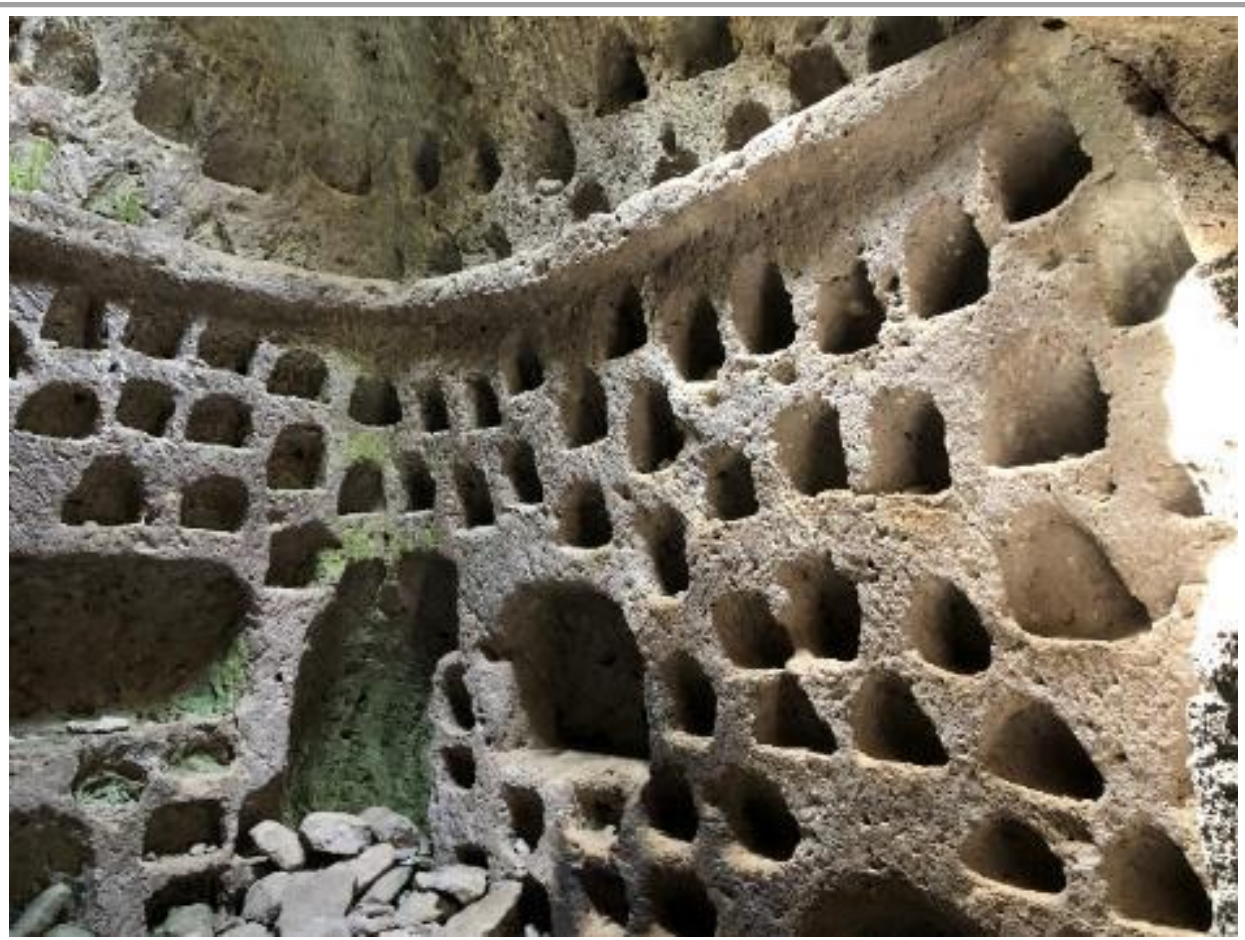

Resim 37: C4 Columbarium Mezarı İçi

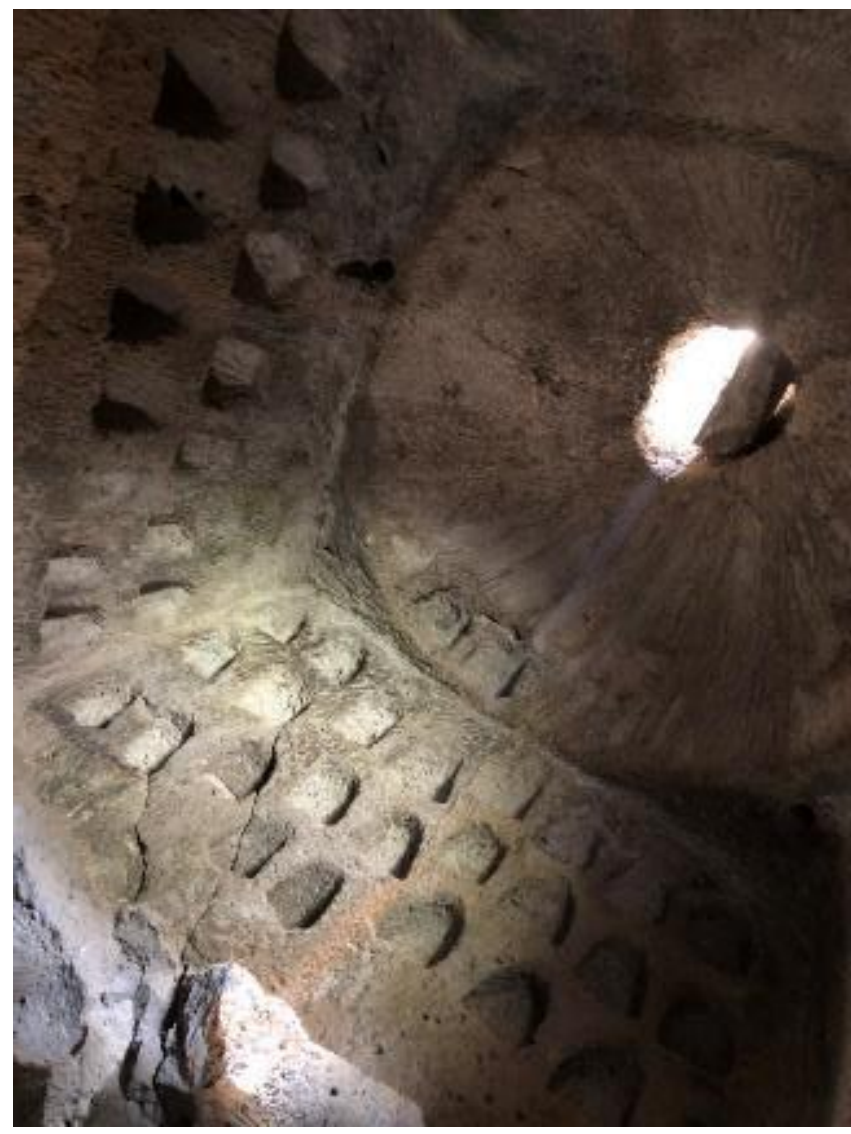

Resim 38: C4 Columbarium Mezarı Tavanı

Turkish Studies - Historical Analysis

Volume 14 Issue 3, 2019 


\begin{abstract}
Kodu C5
Konumu Yusuf Tepesi Yamac1, Turan

Açıklama Yapı, vadi yamacının yumuşak tüf kayaları içerisine girilecek şekilde oyulmuştur. Giriș kapısının büyük kısmı toprak altındadır. Giriş kapısına yaklaşık ikişer metre mesafede üçgen formunda ve üç metre uzunluğunda azalan yükseklikli iki duvar ile oluşturulmuş bir açık hava giriş holü bulunmaktadır. Bu giriş bölümü, kutsal bir mekâna giriş yapıldığı hissini uyandırmaktadır. Toprak altındaki kısmı da dahil olmak üzere yaklaşık $106 \mathrm{~cm}$ genişliğinde ve $160 \mathrm{~cm}$ yüksekliğindeki üst kısmı yarım daire şeklindeki giriş kapısının çevresinde süslemeler göze çarpmaktadır, kapı batıya bakmaktadır. Bu kapının ardında dikdörtgen planlı, yaklaşık " $678 \times 267$ cm" ölçülerinde tavanı işlemeli ve duvarları çok sayıda urne nişi barındıran bir oda bulunmaktadır. Odanın tavanı yarım daire şeklinde ince işçilikle oyulmuştur. Bu odanın duvarlarında 120 civarında urne nişi yer almaktadır, bu nişler oldukça yıpranmış durumdadır, genel olarak yarım daire formunda kazılmışlardır ve ortalama " $35 \times 30 \mathrm{~cm}$ " ölçülerindedirler. Odanın güney kısmında doğu ve batı yönlerinde karşılıklı iki adet yarım daire şeklinde girinti vardır. Bu girintilerin içerisi de yine mezar nişleri barındırmaktadır. Tavan yüksekliği $312 \mathrm{~cm}$ olup tavanda merkezde olmayan, kırılma usulü ile açılmış olan $100 \mathrm{~cm}$ çapında bir baca deliği bulunmaktadır. $\mathrm{Bu}$ deliğin yüzeydeki kısmına yığma taş ile baca örülüdür. Yine tavan bölgesinde yaklaşık 10 cm çapında dar bir tünel bulunmaktadır, bu tünel dışarıya bağlanmaktadır.
\end{abstract}

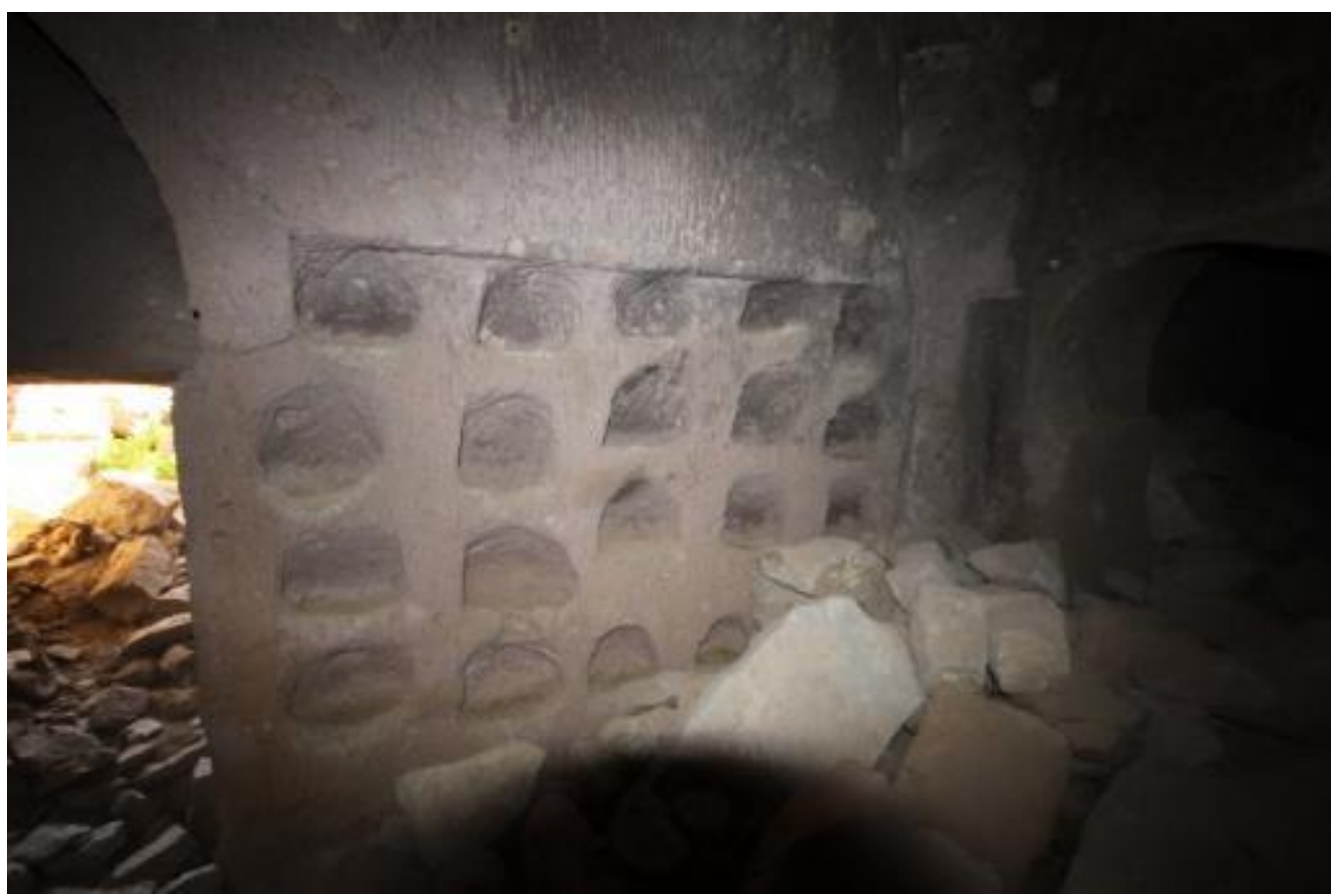

Resim 39: C5 Columbarium Mezar İçi 


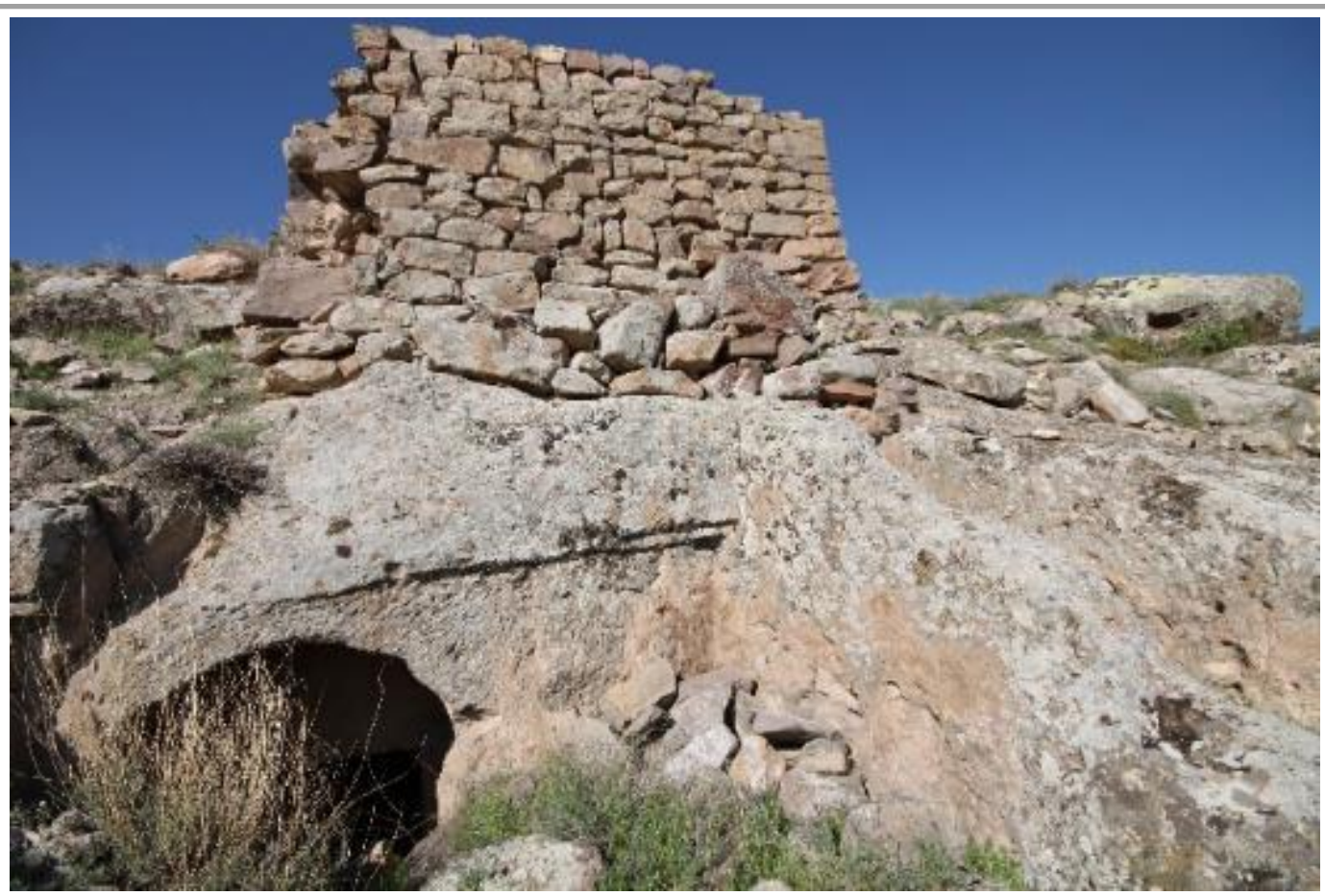

Kodu C6

Resim 40: C5 Columbarium Mezarı Giriş Kapısı ve Üstüne Eklenen Baca

Konumu Vekse'den Vadiye İniş Yolu Batısı

Açıklama Vadinin eğimli yamacının kuzeye bakan kısmına kazılmış olan bu yapının, sonradan kırılarak açıldığı anlaşılan bozuk formlu bir kapısı ve penceresi bulunmaktadır. Yap1 içerisine girildikten sonra " $500 \times 311 \mathrm{~cm}$ " ölçülerinde giderek yükselen zemine sahip bir oda karşılamaktadır. Bu odanın zemini yaklaşık birer metre aralıkla ellişer santimlik iki basamak barındırmaktadır. Tavan yapının sonuna doğru iyice basıklaşmaktadır. $\mathrm{Bu}$ yapıda diğerlerinden farklı olarak bir kolon bulunmaktadır. Kolonun yüzeyleri de dahil olmak üzere yapının tamamı düzgün üçgen formlu mezar nişleri ile kaplıdır. Mezar nişlerinin " $28 \times 26 \mathrm{~cm}$ ” olduğu görülmektedir. Tavanın en yüksek olduğu noktada $320 \mathrm{~cm}$ olduğu ölçülmüştür. Yaklaşık 200 adet urne nişi bu yapının içerisinde yer almaktadır. Yapı içerisindeki kolonun bir yüzünde kökboyası kalıntıları göze çarpmaktadır. Yapının zemininde $47 \mathrm{~cm}$ çapında kapak genişliği ve $120 \mathrm{~cm}$ derinliği olan bir yer altı deposu bulunmaktadır. Yapının güney batı köşesinde $86 \mathrm{~cm}$ çapında bir baca kırığı yer almaktadır. Yapı içerisinde bir tane de dişarıyla bağlantılı $10 \mathrm{~cm}$ 'lik dar tünel bulunmaktadır. Bu yapının içerisindeki mezar nişleri benzerlerine kıyasla oldukça iyi durumdadır. 


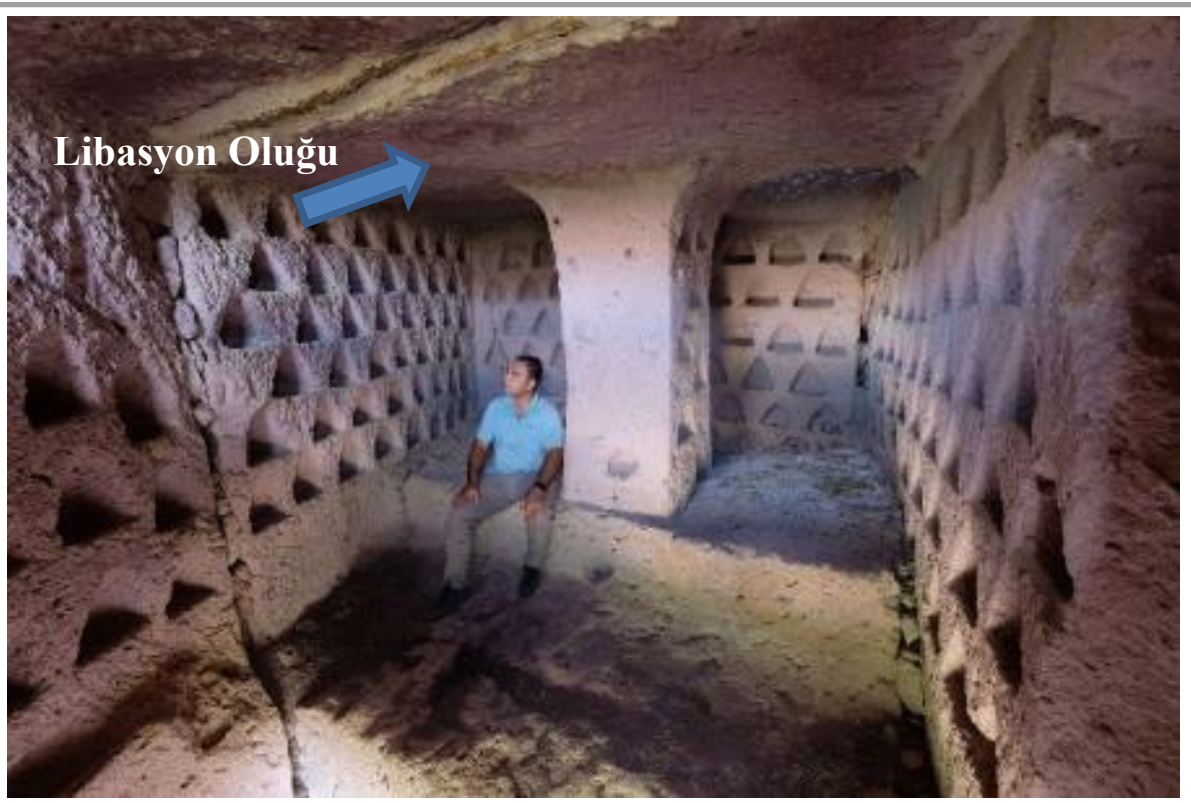

Resim 41: C6 Columbarium Mezarı İçi ${ }^{4}$

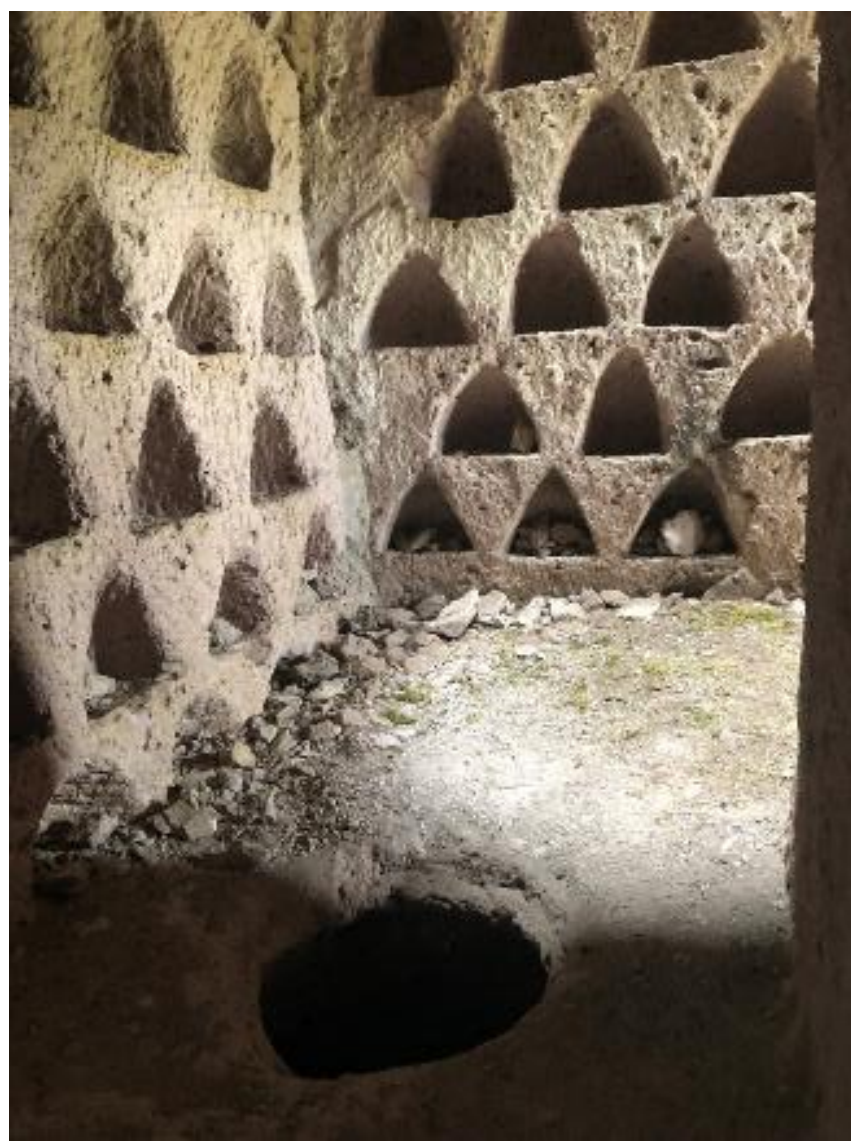

Resim 42: C6 Columbarium Mezarı İçi (Silo Zeminde)

\footnotetext{
${ }^{4}$ Fotoğraf: Reiner Straub
}

Turkish Studies - Historical Analysis

Volume 14 Issue 3, 2019 
Kodu

Konumu

Açıklama

\section{C7}

Isbıdın Köyü Doğu Çift Apsisli Kilise Bitişiği

Vadinin eğimli yamacının güneye bakan yamacına kazılmış olan bu yapıya dışarıdan bakınca iki kapı görülmektedir. Bu kapıların ikisi de dikdörtgen kesimli ve yukarıdan yarım daire nişli kapılardır. Kapılardan doğudaki çift apsisli bir kiliseye açılırken batıdaki columbarium mezara açılmaktadır. Kapı "127x180 cm" ölçülerinde olup tavanı yarım daire şeklinde dikdörtgen planlı "1030x405" $\mathrm{cm}$ ölçülerinde büyük bir odaya açılmaktadır. Giriș kapısının açıldığı odanın sonunda yer alan " $125 \times 180 \mathrm{~cm}$ " ebatlı düzgün kapı göze çarpmaktadır. Bu oda içerisine girildiğinde kubbesel mimariye sahip bir columbarium mezar bulunmaktadır. " $433 \times 459$ cm" taban ölçüsüne sahip bu yapının, yüksekliği $652 \mathrm{~cm}$ 'dir, oldukça yüksek olan bu yapı ihtişamlı durmaktadır. Kubbenin merkezinin yaklaşık $236 \mathrm{~cm}$ altından yatay bir niş kubbe boyunca geçmektedir. Yap1 içerisinde büyük çoğunluğu su etkisiyle erimiş halde yarım daire formlu " $29 x 28 \mathrm{~cm}$ " boyutlarında mezar nişleri yer almaktadır. Bu yapıda tavana yakın noktada bir de küçük bir oyma oda bulunmaktadır. Yaklaşık 250 adet urne nişi barındıran bu yapının zemininde $85 \mathrm{~cm}$ ağı çapı olan bir yer altı deposu da bulunmaktadır, bu deponun aşağıda bir başka odaya açıldığı ama girişin çok dar olduğu görüşmüştür. Yapının tavanında merkezde olmayan, kırıldığı çok belli olan $100 \mathrm{~cm}$ çapında bir baca deliği bulunmaktadır. Bu delik dışarıdan baca olarak örülmüştür. Yapının tavan kısmında yaklaşık $10 \mathrm{~cm}$ çapında dışarıya bağlanan dar bir tünel bulunmaktadır.

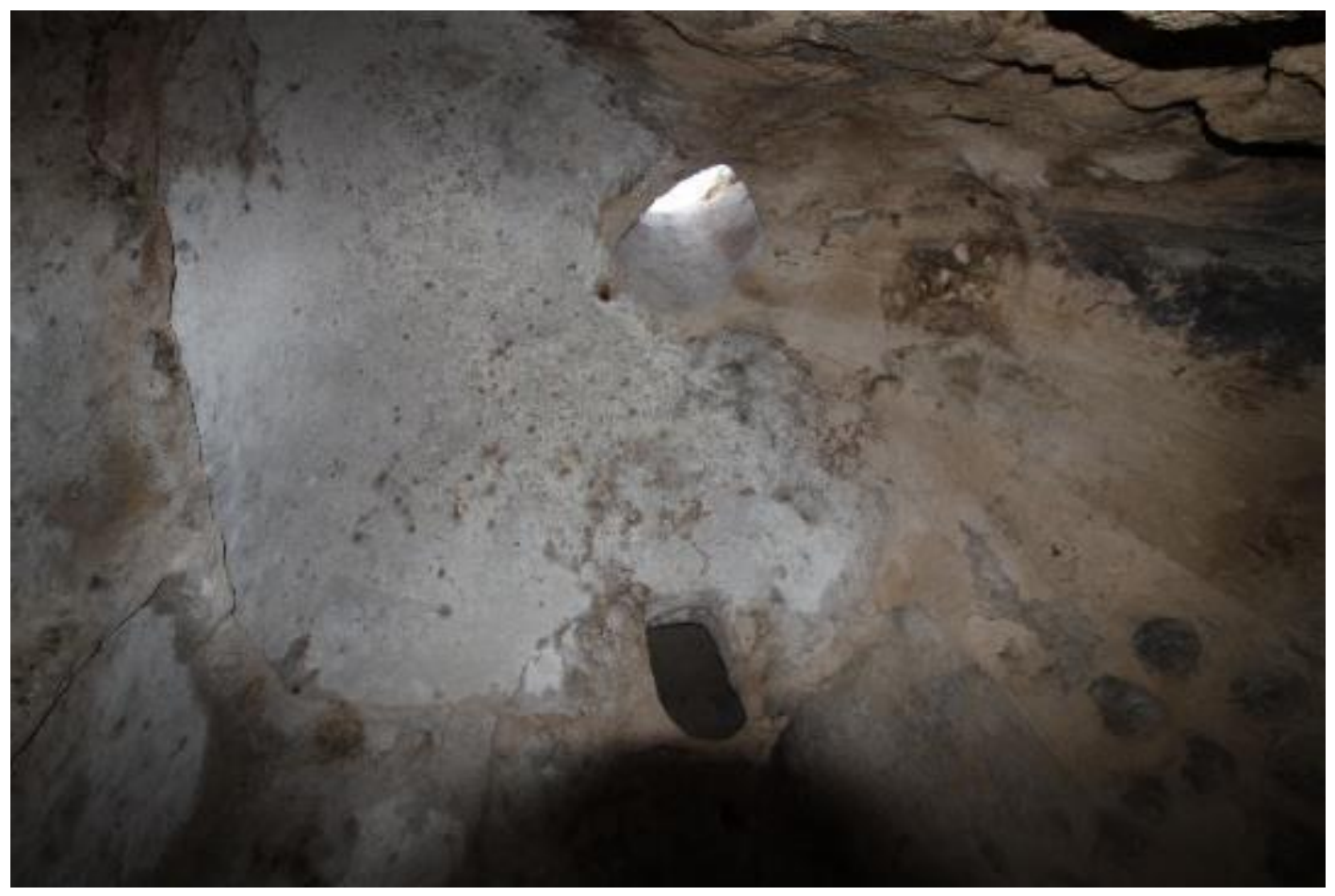

Resim 43: C7 Columbarium Mezarı Tavanı 


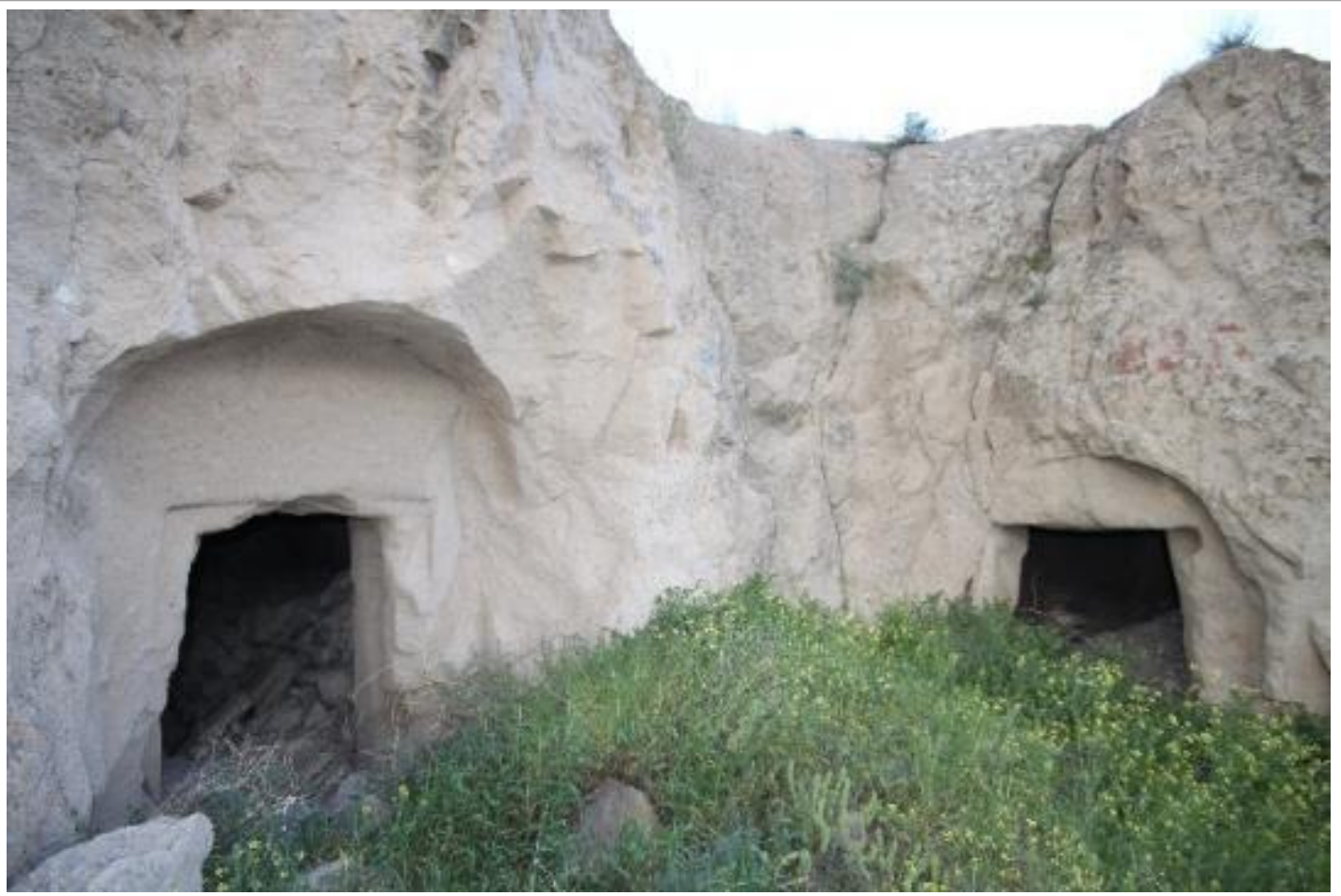

Resim 44: C7 Columbarium Mezarı Girişi

Kodu

Konumu

Açıklama
C8

Akbin Deresi, Öküz İni Mevkii

Tavanı yarım daire şeklinde oyulmuş bir oda şeklinde tasarlanmış bu yapının giriş kapıs1 yıkılmıștır. Yap1 vadi yamacına oyulmuştur ve giriş kapısı güneye bakmaktadır. Ana giriș kapısı "305x208" cm ölçülerinde bir odaya açılmakta ve girişin batısında yer alan bugün yıkılmış olan ikinci kapı ile columbarium mezar odasına varılmaktadır. Oda içerisinde bulunan nişler genellikle üçgen formda oyulmuştur ve "33x32 cm" ölçülerindedir. Oda "787x255 cm" ölçülerinde olup tavan yüksekliği $276 \mathrm{~cm}$ 'dir. Yapının yaklaşık 50 adet urne nişi barındırdığı görülmüş̧ür. Yapının kuzey tarafında dairesel küçük bir oda daha bulunmaktadır. Bu columbarium mezarda farklı olarak bir sıra nişin daha büyük ve belli bir çizgisel niş ile ayrılarak yapıldığ görülmektedir. Bu yapının içerisinde kapak çapları yaklaşık $75 \mathrm{~cm}$ olan 6 adet yer altı deposu bulunmaktadır. 


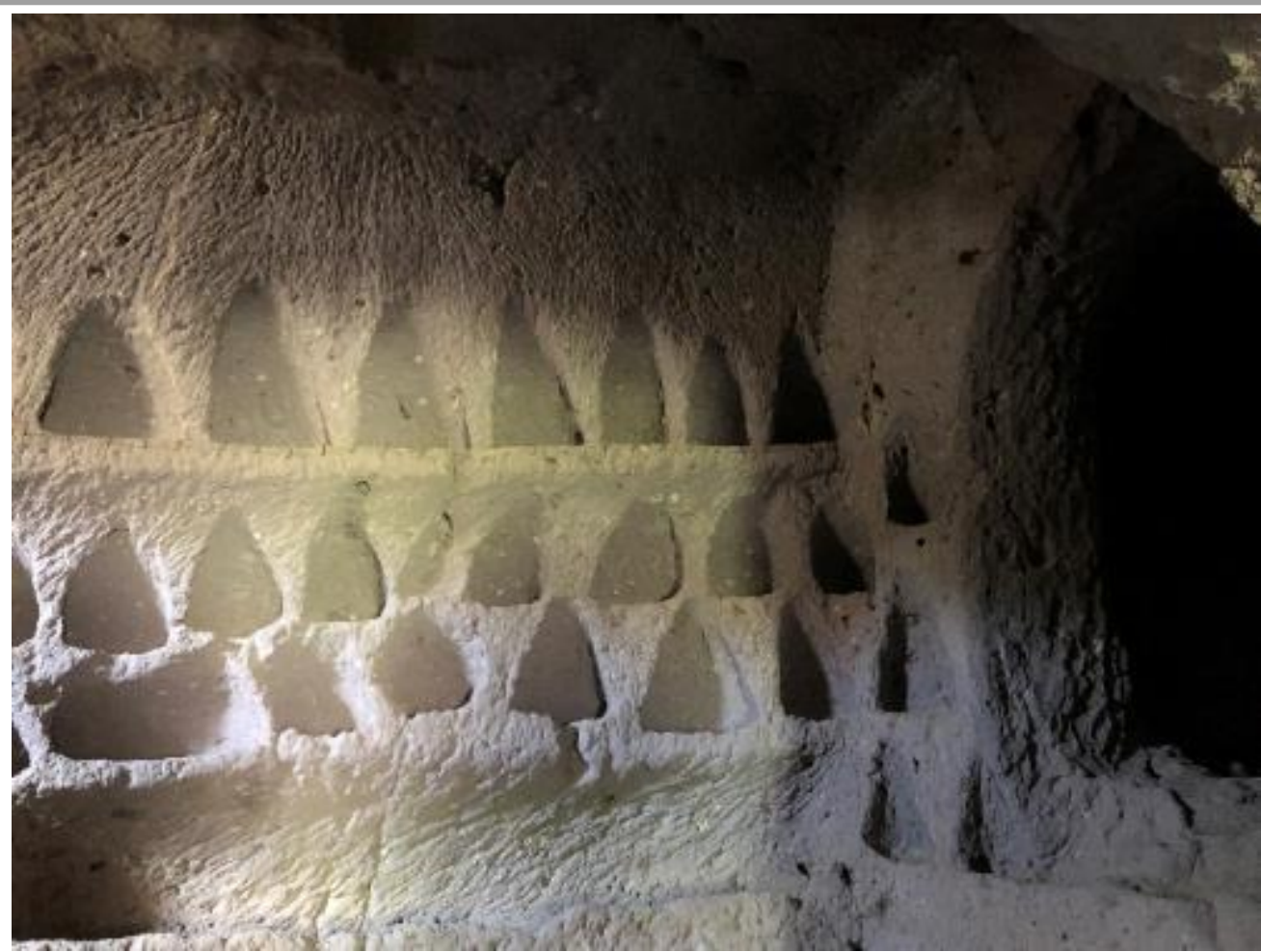

Resim 45: C8 Columbarium Mezarı İçi

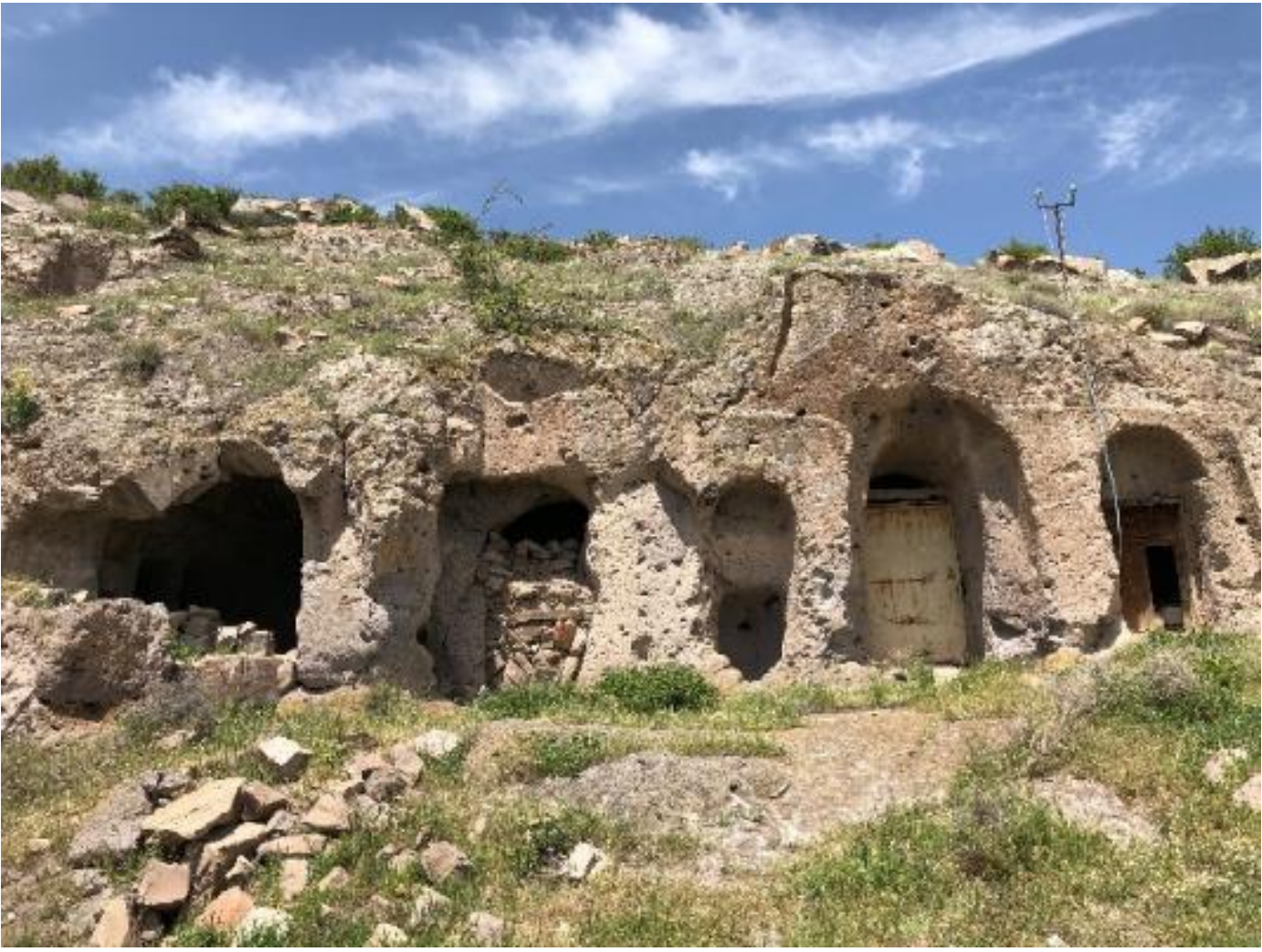

Resim 46: C8 Columbarium Mezarı Girişi

Turkish Studies - Historical Analysis

Volume 14 Issue 3, 2019 


\begin{abstract}
Kodu C9
Konumu $\quad$ Akbin Deresi, Öküz İni Mevkii

Açıklama Vadi yamacına oyulmuş bu yapıya yol çalışması sırasında yıkılmış bir girişin ardından varılan "580x331 cm" ölçülerindeki dikdörtgen planlı bir odanın içerisinden varılmaktadır. "310x312 cm" taban genişliğine sahip kubbesel yapıdaki bu columbarium mezarın tavan yüksekliği $590 \mathrm{~cm}$ 'dir. Tavan $330 \mathrm{~cm}$ yükseklikte iken bir boğum barındırmaktadır, bu boğumdan sonra yapı tekrar genişten dara doğru kubbeye dönüşmektedir. Bu boğumun altı da üstü de mezar nişleri ile bezelidir. Sayıları 100 kadar olan bu mezar nişlerinin "28x32 cm" olduğu ölçülmüştür. Yapının tavanında merkezde olmayan kırık şeklinde $100 \mathrm{~cm}$ çapında bir baca yer almaktadır. Bacanın yukarıdaki kısmında herhangi örme bir baca görülmemiştir. Bu yapının önünde ve yukarısında kaya oyma mezarlar bulunmaktadır.
\end{abstract}

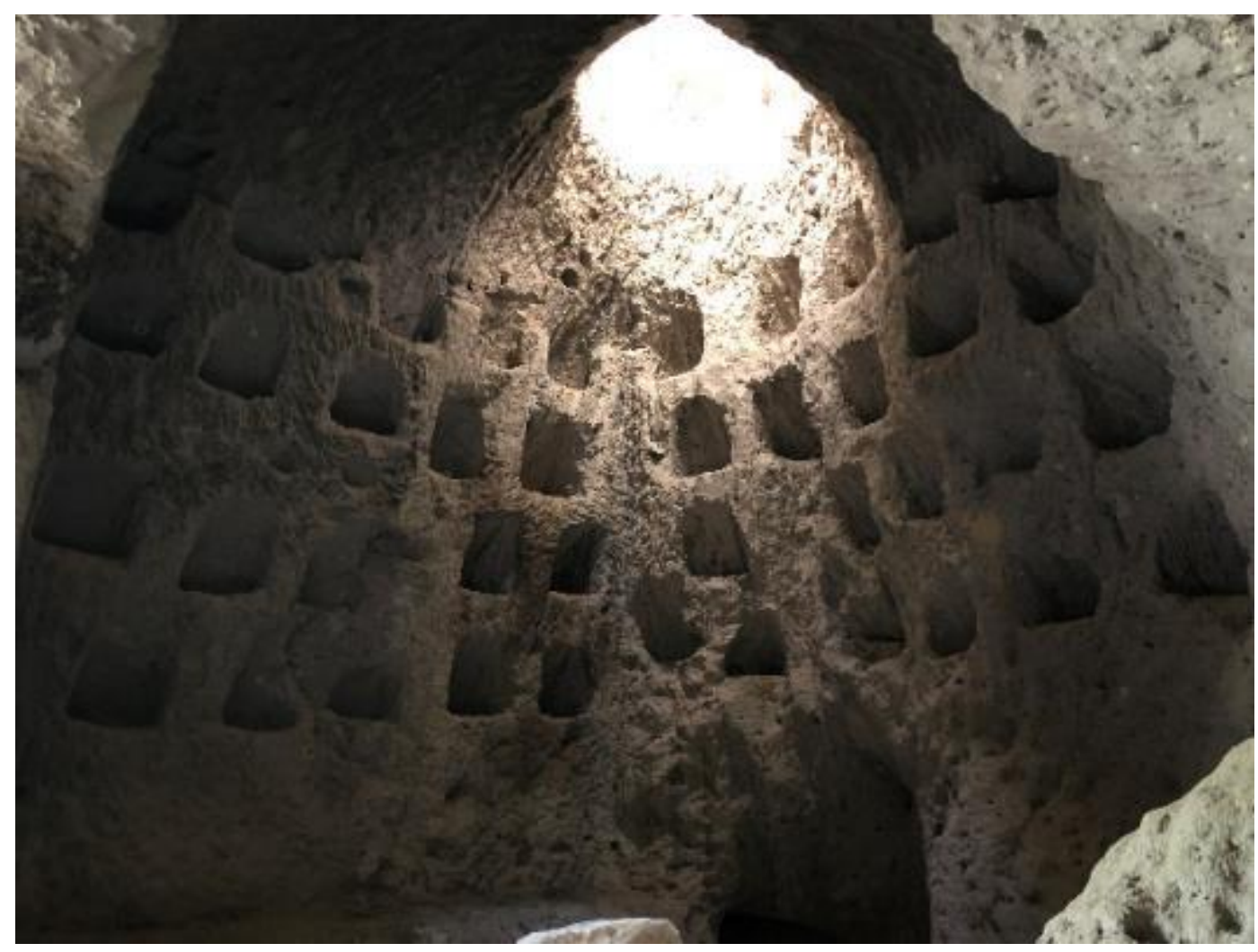

Resim 47: C9 Columbarium Mezarı İçi 


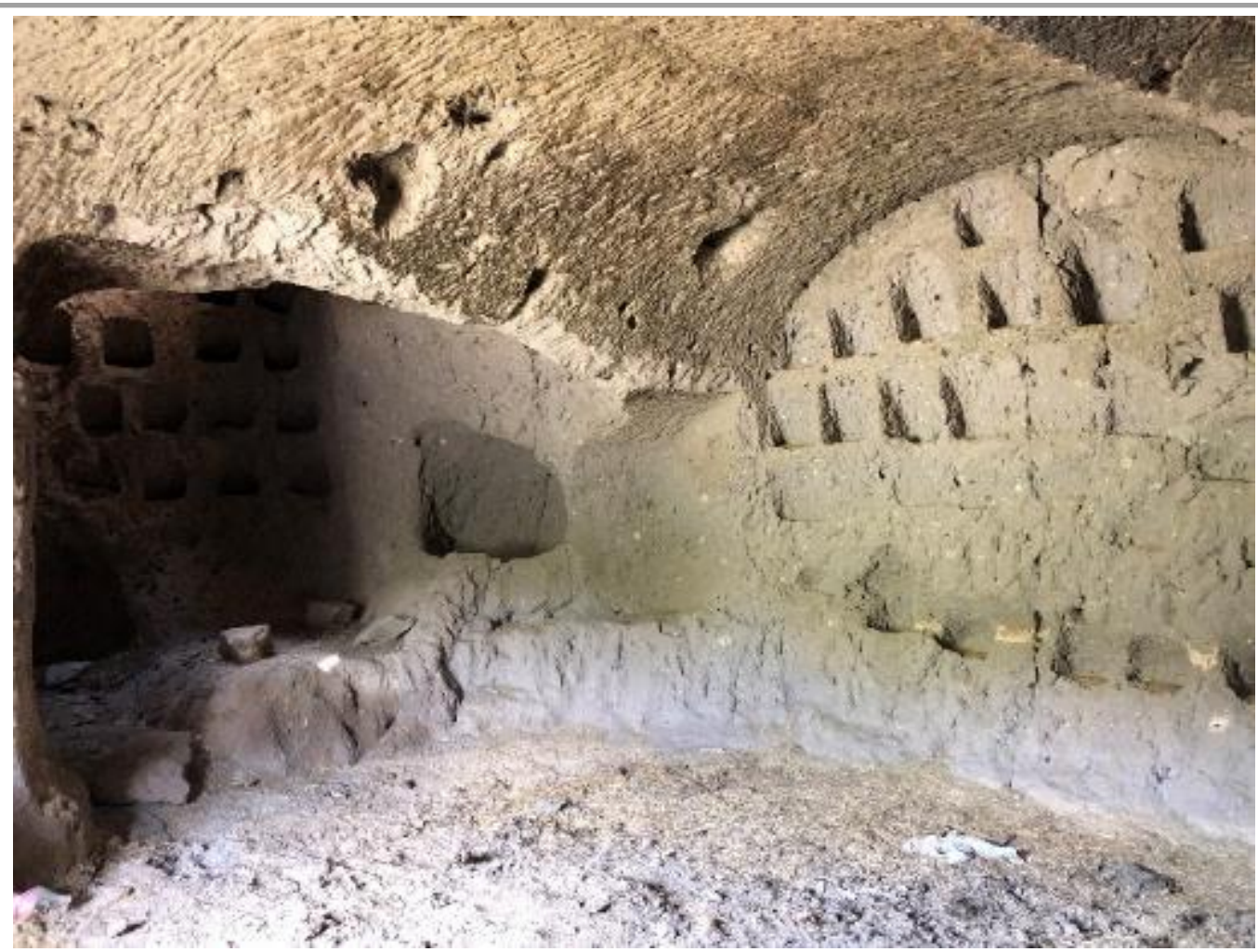

Resim 48: C9 Columbarium Mezarı Giriş Odası

Kodu

Konumu

Açıklama

\section{C10}

Akbin Deresi, Öküz İni Mevkii

Vadi yamacına oyulmuş yapının giriş kapısı yıkılmıştır, iç oda kapısı olduğu anlaşılan ikinci bir kapı ile girilen oldukça hasar görmüş " $545 \times 656 \mathrm{~cm}$ " ölçülerindeki dikdörtgen planlı bir odanın içinde ise iki kapı bulunmaktadır. Kuzeydeki kapı bir başka odaya aç11ırken kuzey doğudaki kapı columbarium mezara ulaşmaktadır. Bu yapıda diğerlerinden farklı olarak iki katlı bir yapı görülmektedir. Genel anlamda kubbesel formda olan yapının içerisinde üstüne çıkılabilen ve yerden yaklaşık $250 \mathrm{~cm}$ yukarıda bulunan balkon benzeri bir alan bulunmaktadır. Burada $52 \mathrm{~cm}$ kapak ağız genişliği olan bir yer altı deposu ve genişçe bir urne nişi bulunmaktadır. Yapının taban genişliği " $235 \times 334 \mathrm{~cm}$ " olup tavan yüksekliği $539 \mathrm{~cm}$ 'dir. Mezar nişleri oldukça bozulmuş ve yarım daire formunda olup " $24 \times 31 \mathrm{~cm}$ " ölçülerine sahiptir. Yaklaşı 50 adet urne nişi bulunmaktadır. Kırık şeklinde açılmış olan bacanın ise çapı yaklaşık 100 cm’dir. Bu yapı oldukça yıpranmış durumdadır. 


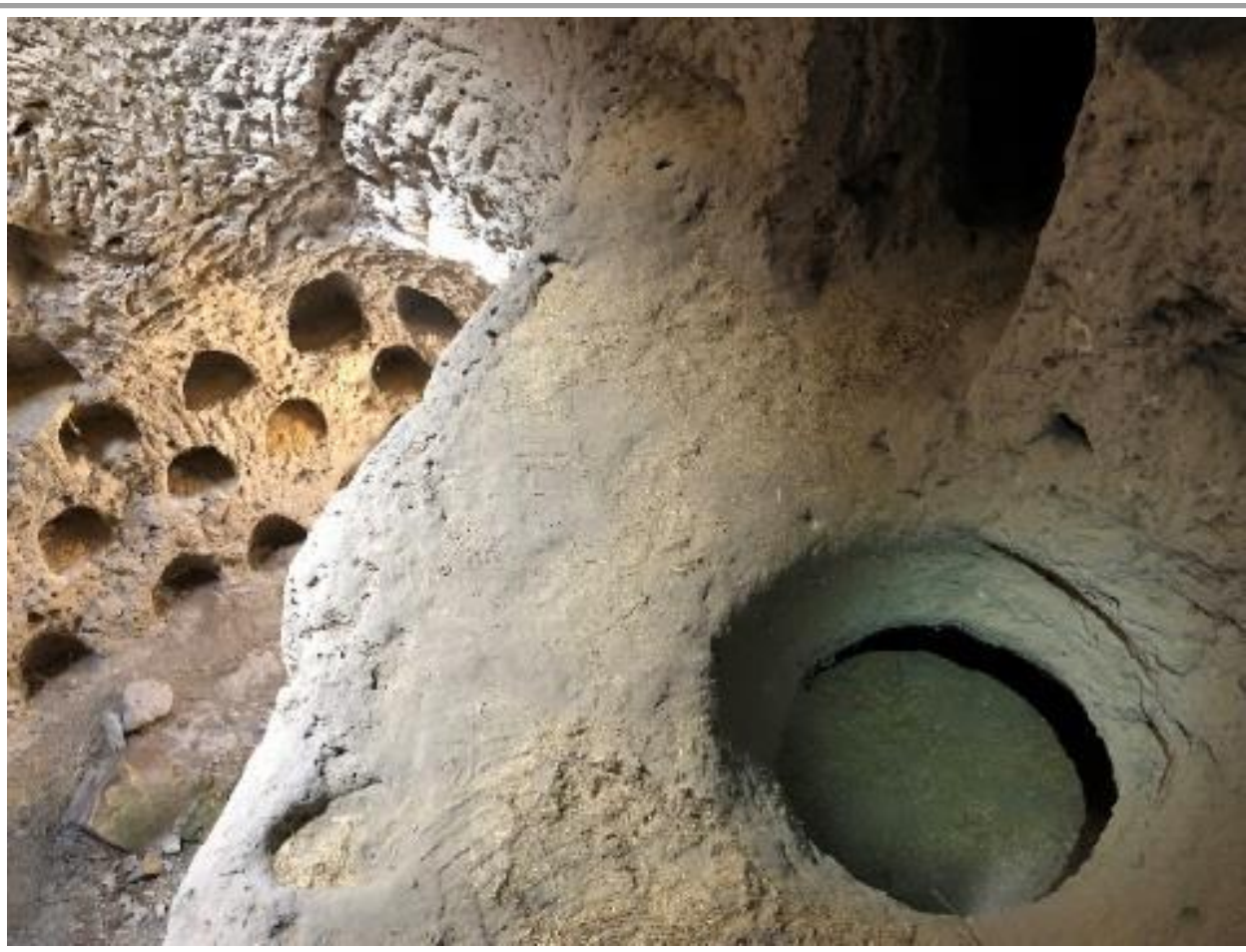

Resim 49: C10 Columbarium Mezarı İçi (Silo Zeminde)

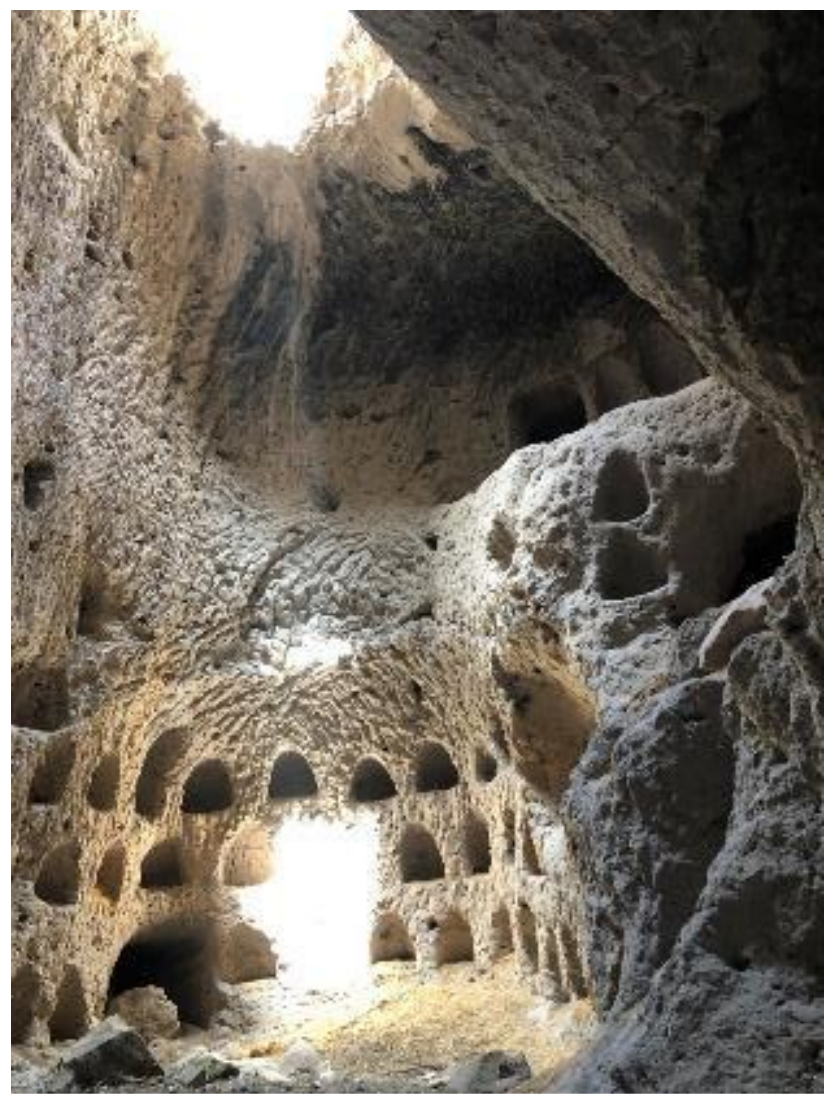

Resim 50: C10 Columbarium Mezarı İçi 


\section{Kodu C11 \\ Konumu Akbin Deresi, Öküz İni Mevkii \\ Açıklama Vadinin güneye bakan yamacına oyulmuş bu yapının giriş kapısı yıkılmış durumdadır, mevcut giriș kapısı bir iç oda kapısı olmalıdır. Bu kapıdan girince benzerlerinde olduğu gibi " $973 \times 468$ cm" ölçülerinde dikdörtgen planlı genişçe bir oda ile karşılaşılmaktadır. Odanın batı duvarında yer alan ikinci ve çevresi nişlerle süslü bir kapının ardından columbarium mezara ulaşılmaktadır. Bu kapı " $82 \times 191$ cm" ölçülerine sahiptir. Kubbesel tasarıma sahip yapının taban ölçüleri “ $373 \times 363 \mathrm{~cm}$ ” olup tavan yüksekliği $558 \mathrm{~cm}$ ' dir. Bu columbarium mezarda farklı olarak küçük mezar nişleri bulunmamaktadır. Bunun yerine yarım daire şekilli $60 \mathrm{~cm}$ çaplı küçük odacıklar bulunmaktadır. Bu odacıkların bir kısmı yerden $302 \mathrm{~cm}$ yukarıda bulunan yatay nişin üzerinde yer almaktadır. Yaklaşık 10 kadar bu biçimde urne nişi bulunmaktadır. Kırılma yolu ile açılan bacasının çapı ise yaklaşık 50 cm'dir.}

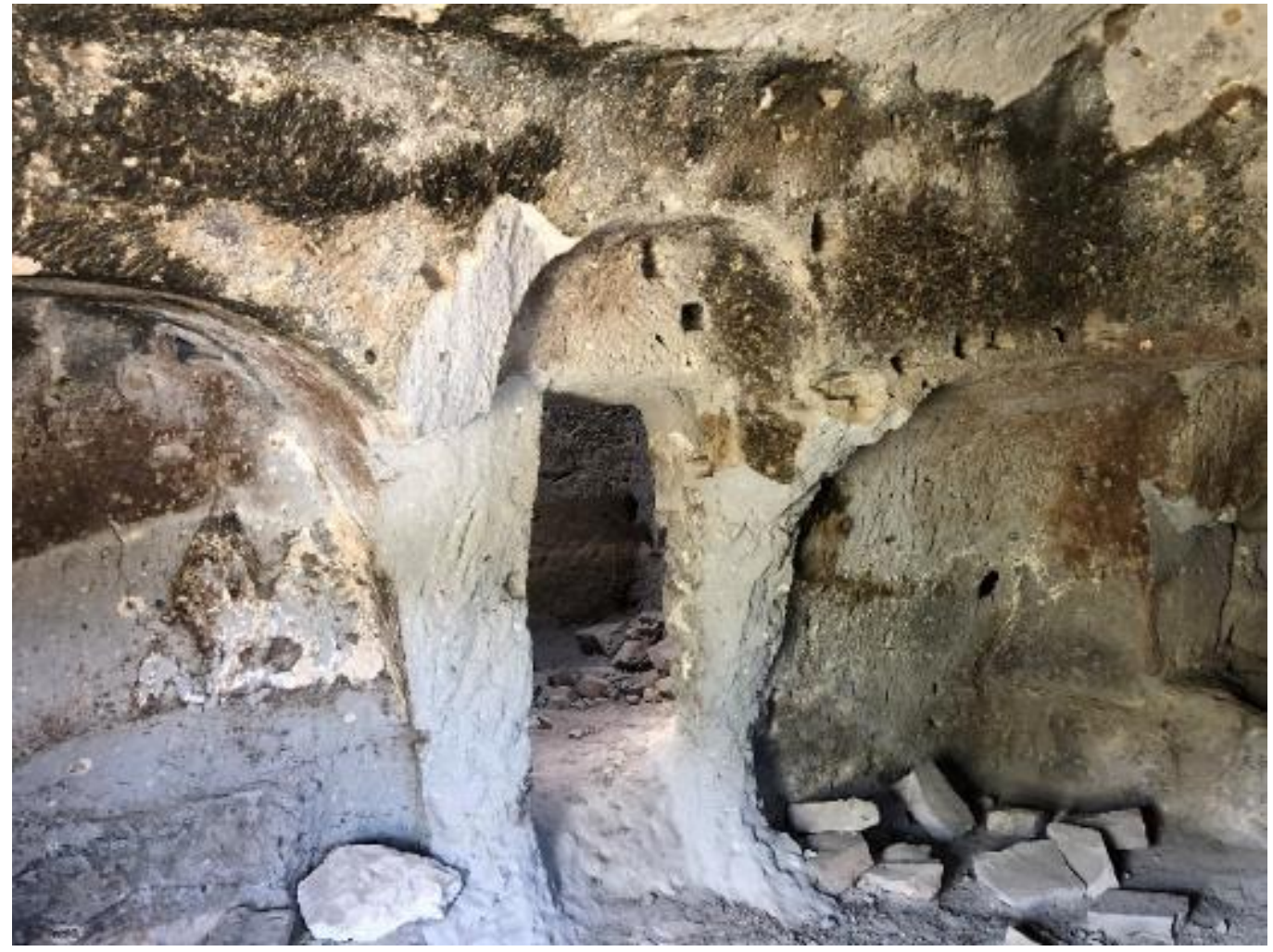

Resim 51: C11 Columbarium Mezarı Giriş Odasına Açılan İç Kapı 


\begin{tabular}{|c|c|}
\hline Kodu & C12 \\
\hline Konumu & Akbin Deresi, Öküz İni Mevkii \\
\hline Açıklama & 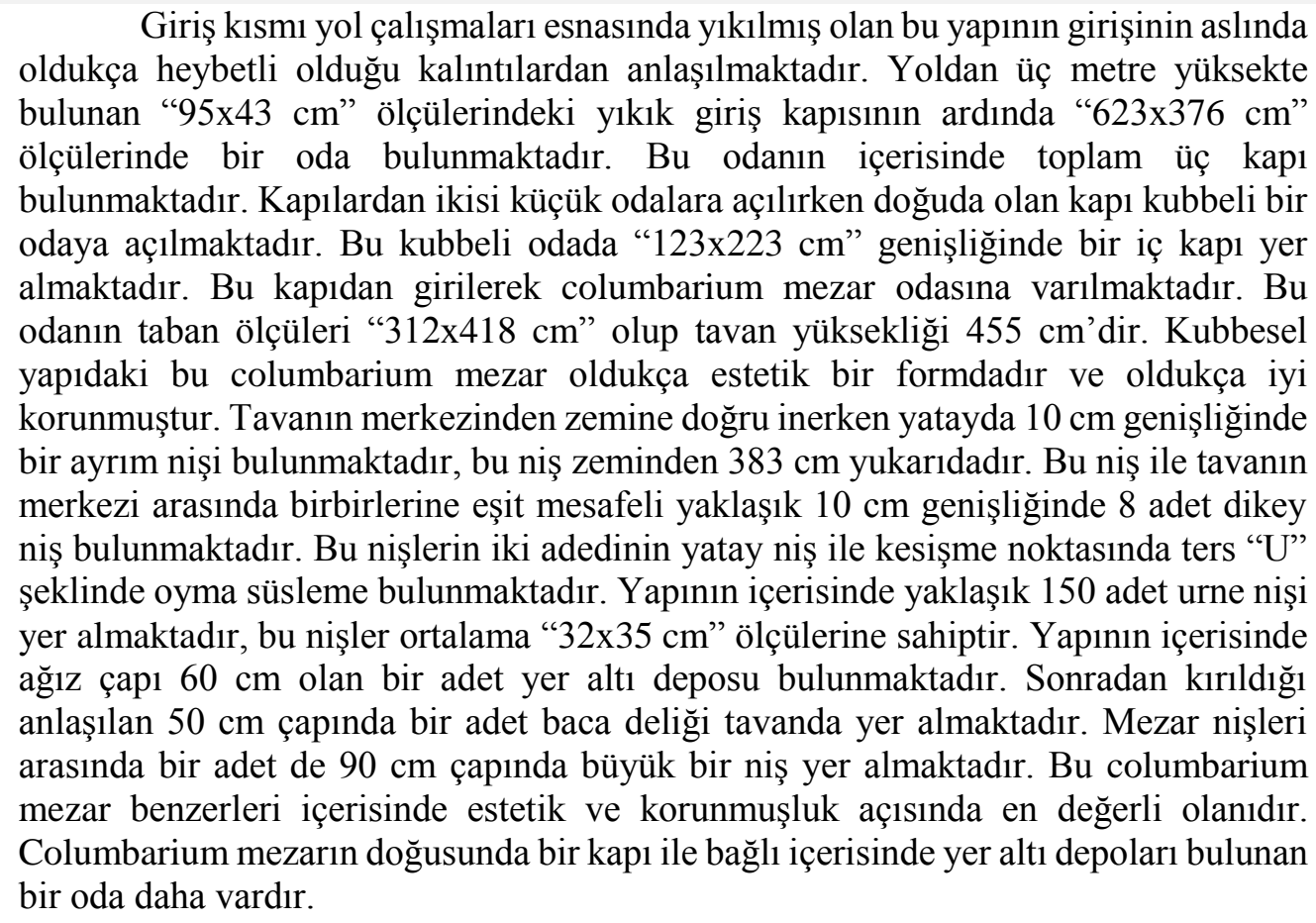 \\
\hline
\end{tabular}

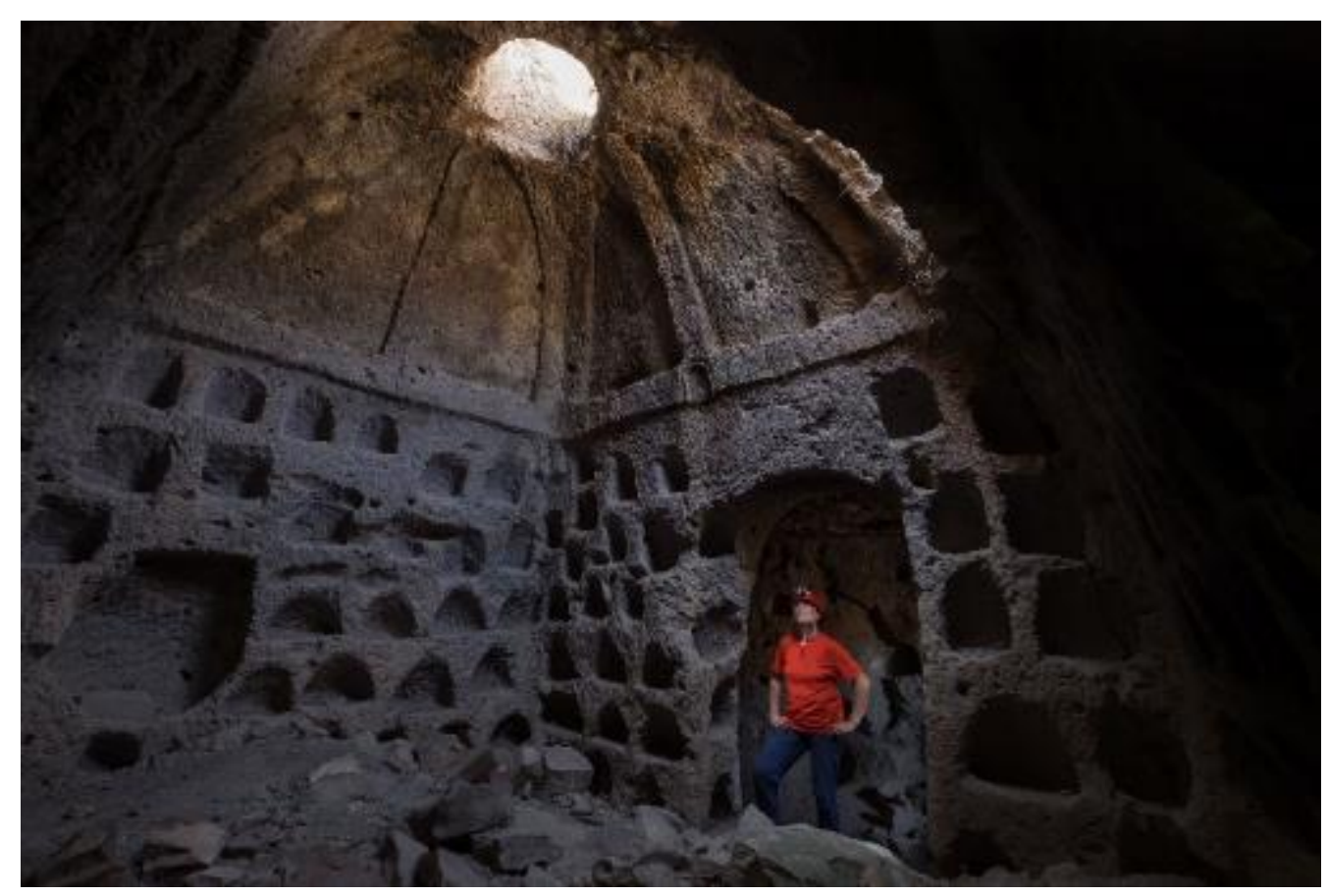

Resim 52: C12 Columbarium Mezarı İçi ${ }^{5}$

\footnotetext{
${ }^{5}$ Fotoğraf: Reiner Straub
} 


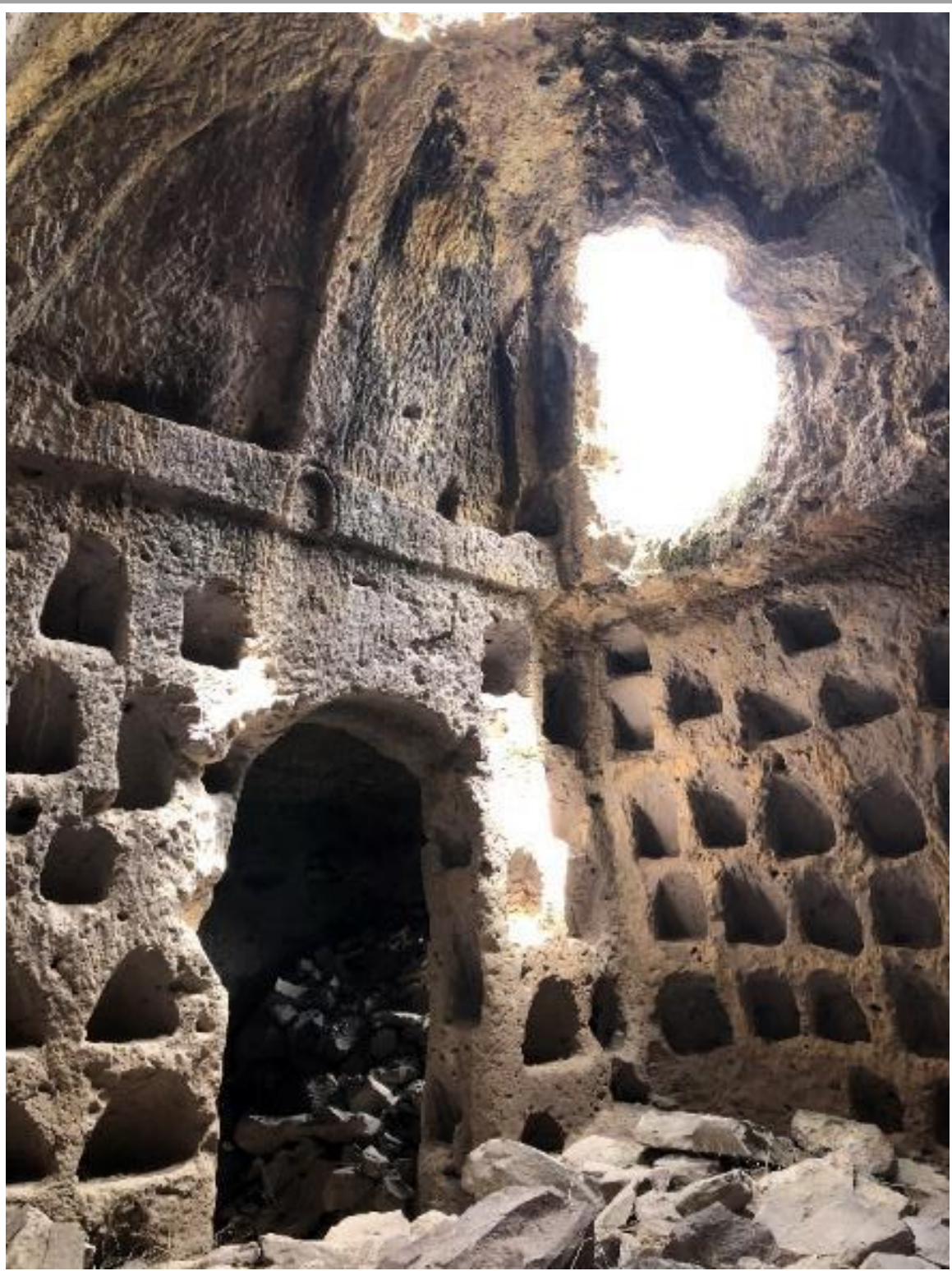

Resim 53: C12 Columbarium Mezarı İçi

Kodu

Konumu

Açıklama

\section{C13}

Akbin Deresi, Öküz İni Mevkii

Girişi toprak altında kalan ve kısmen korunmuş olan bu yapının, girişinde alçalan üçgen duvarlarla çevrili bir hol bulunmaktadır, bu hol vadideki farklı columbarium mezarlarda da bulunmaktadır, girişi yıkılmış yapıların da buna benzer bir girişe sahip oldukları düşünülmektedir. Toprak altındaki giriş kapısının üstündeki dar alandan " $672 x 398$ cm" ölçülerinde bir odaya ulaşılmaktadır, odanın tavanları ustalıkla işlidir. Bu odanın içerisinde " $116 \times 214$ cm" ölçülerinde bir iç kapı yer almaktadır. Bu iç kapıdan columbarium mezar odasına varılmaktadır. Kubbesel forma sahip olan bu yapının kubbe formu benzerlerinden farklıdır ve kubbenin üst kısmı üçgen prizma formundan dairesel forma dönüşmektedir. Kubbesel yapının zemin alanı "333x303 cm” ölçülerine sahip olup 
tavan yüksekliği $614 \mathrm{~cm}$ 'dir. Zeminden $263 \mathrm{~cm}$ yukarıda bir niş yer almaktadır ve bu niş yatayda yapıyı ikiye bölmektedir. İçerisinde 300 civarında urne nişi barındıran yapıdaki mezar nişleri ortalama " $23 \times 25 \mathrm{~cm}$ " ölçüsüne sahiptir. Yapının içerisinde karş1lıklı iki adet yarım daire şeklinde girinti vardır. Yapının tavanında sonradan kırılarak açılan $60 \mathrm{~cm}$ çapında bir baca deliği vardır. Bu yapı kubbe yapısı ile diğer yapılardan ayrılmaktadır.

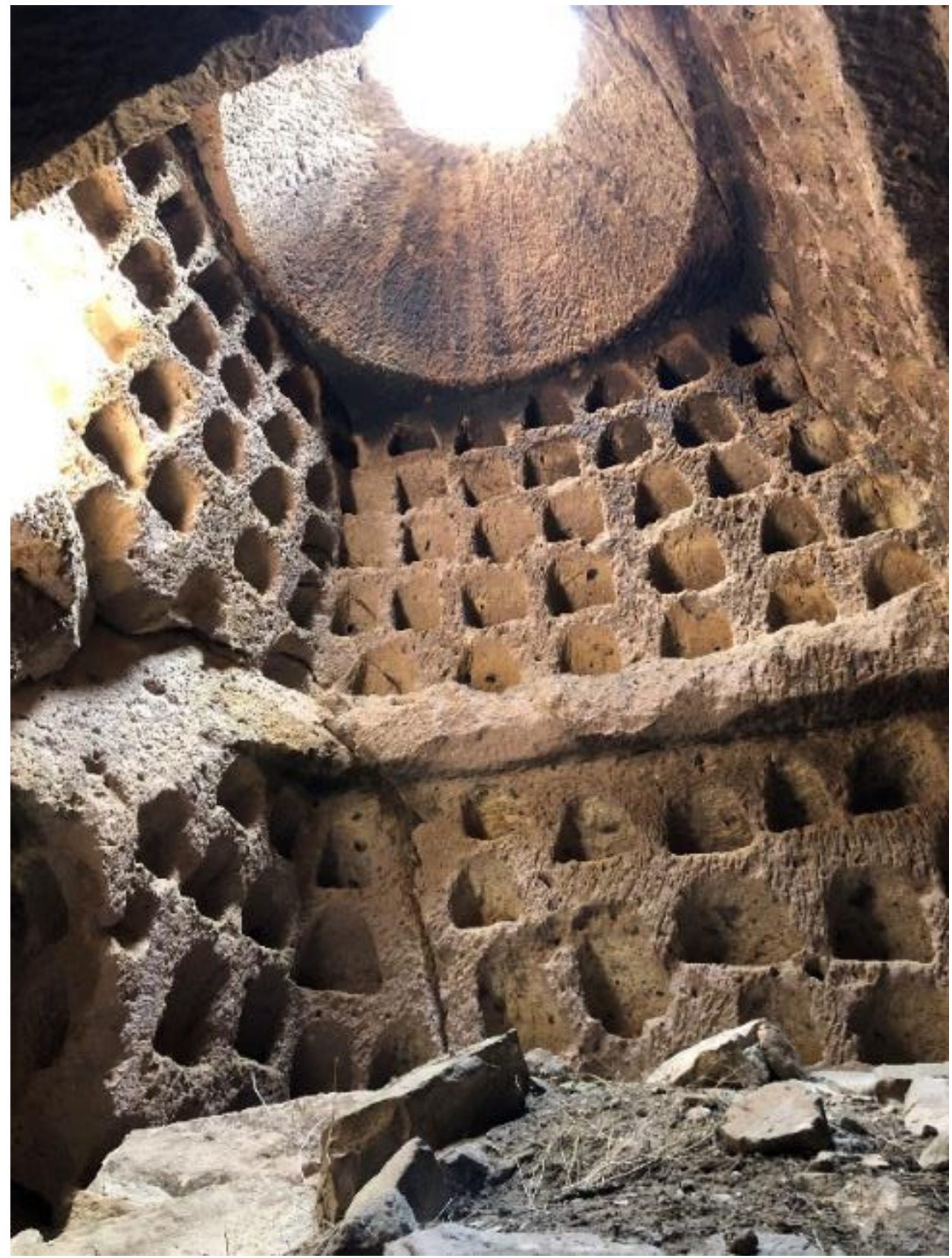

Resim 54: C13 Columbarium Mezarı Tavanı 


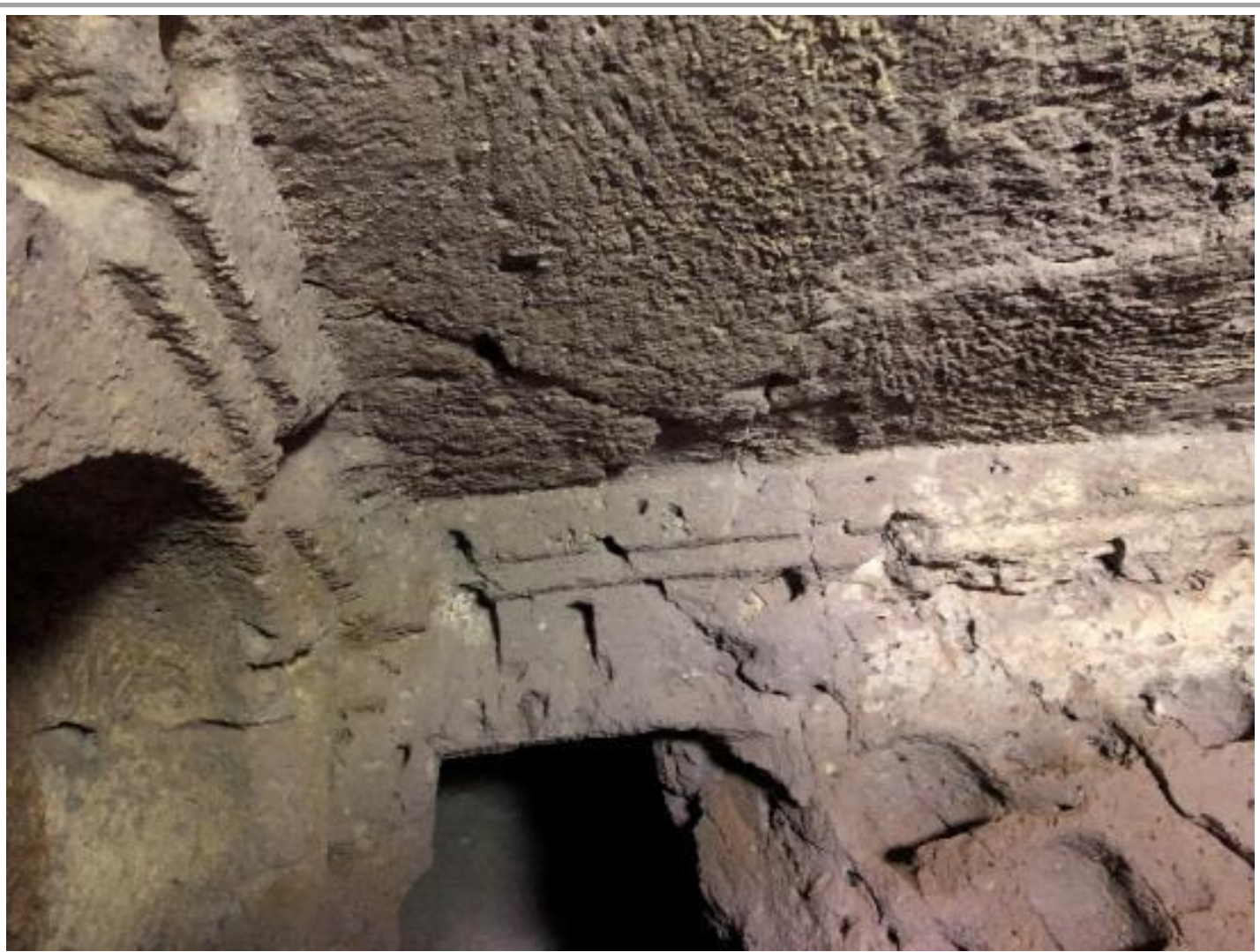

Kodu

Resim 55: C13 Columbarium Mezarı Giriş Odası Tavanı

Konumu

Açıklama

\section{C14}

Akbin Deresi, Öküz İni Mevkii

Ana giriş kapısının ardından tavanı yarım daire şekilli "737x294 cm" ölçülerinde dikdörtgen planlı bir odaya varılmaktadır. Bu odanın içerisinde kırılmış vaziyette bir iç kapı yer almaktadır. Bu kapıdan geçilerek görece küçük bir columbarium mezar odasına varılmaktadır. Bu yapının zemin ölçüleri " $227 \times 201 \mathrm{~cm}$ " dir. Kubbesel formdaki yapı oldukça hasar görmüştür. Yapının tavan yüksekliği $360 \mathrm{~cm}$ 'dir, yerden $257 \mathrm{~cm}$ yukarıda yere paralel $10 \mathrm{~cm}$ kalınlığında bir niş yer almaktadır. Yapının duvarlarında yaklaşık 100 adet ortalama "28x35 cm" ölçülerinde urne nişi bulunmaktadır. Yapının tavanında merkezde olmayan $50 \mathrm{~cm}$ çapında kırık şeklinde baca bulunmaktadır. Bu columbarium mezar diğer örneklere kıyasla küçük ve oldukça yıpranmıştır.

Turkish Studies - Historical Analysis

Volume 14 Issue 3, 2019 


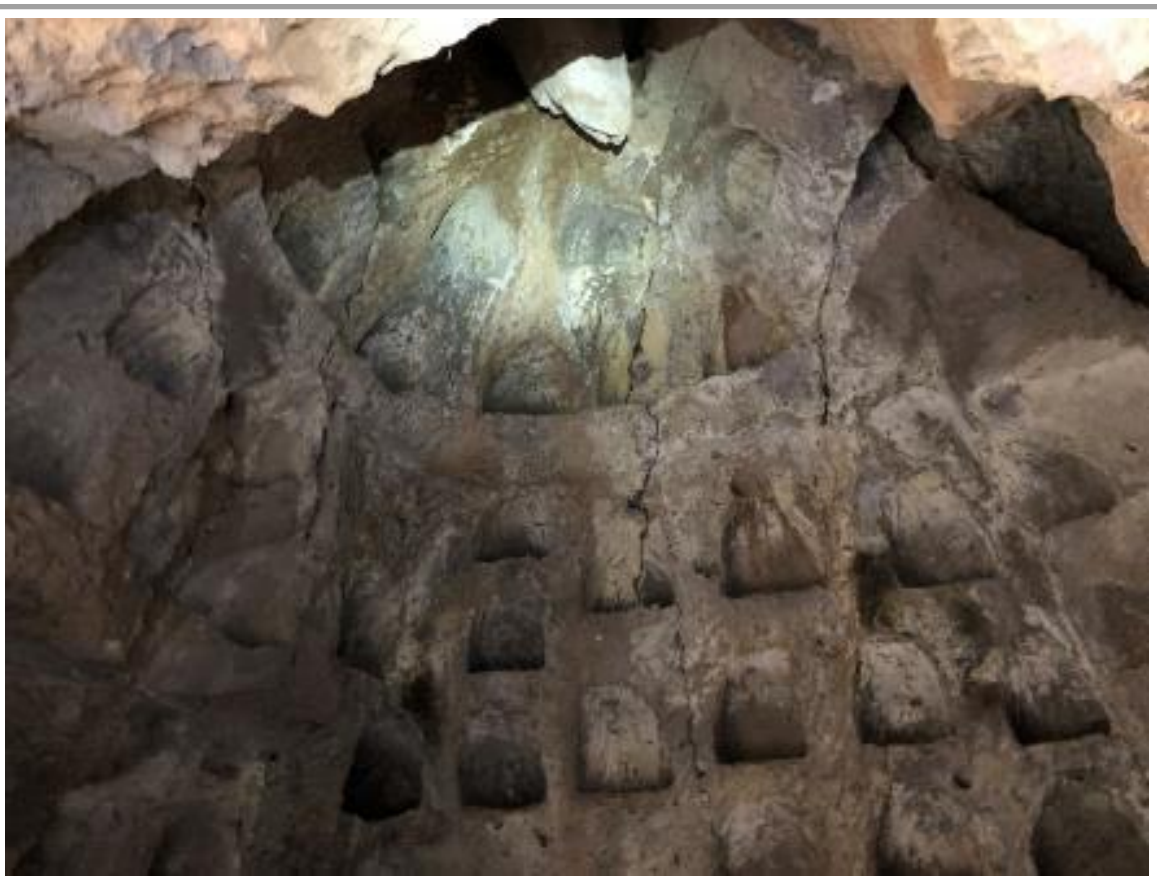

Resim 56: C14 Columbarium Mezarı İçi

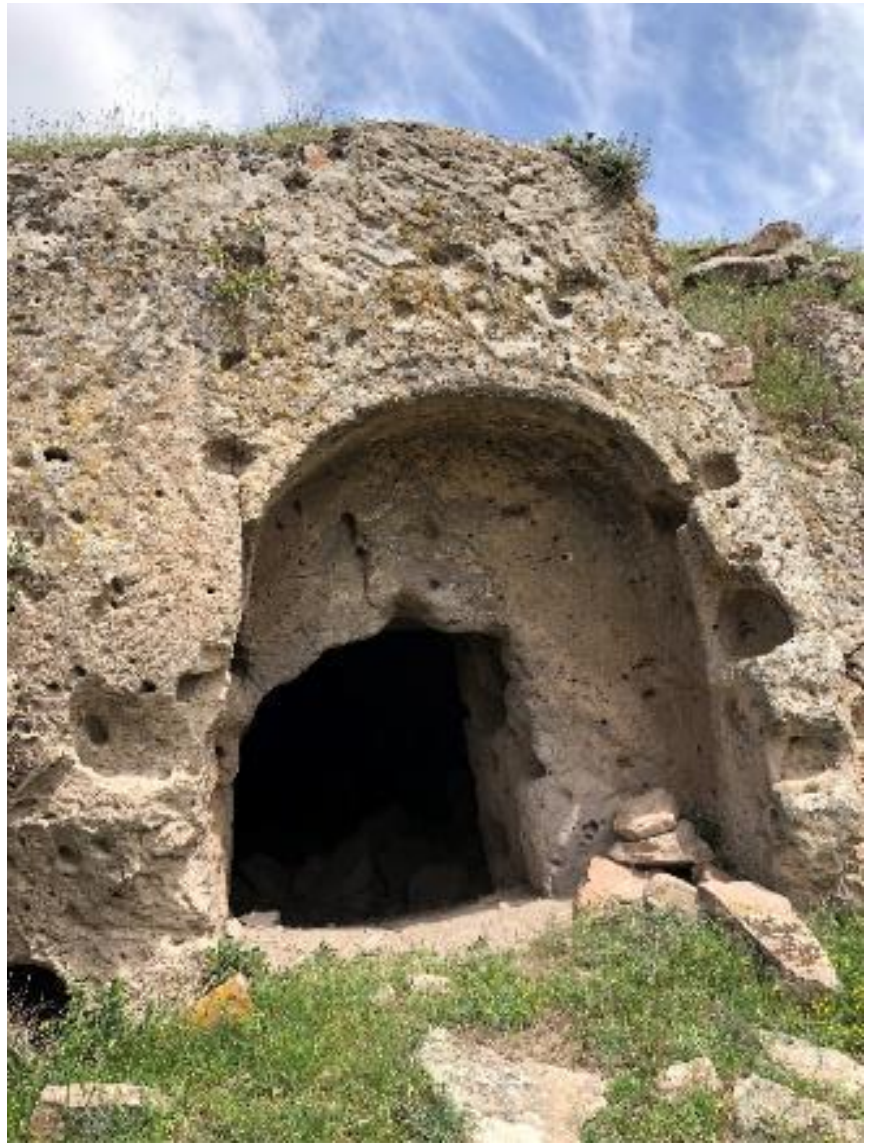

Resim 57: C14 Columbarium Mezarı İçi

Turkish Studies - Historical Analysis

Volume 14 Issue 3, 2019 
Kodu

Konumu

Açıklama

\section{C15}

Akbin Deresi, Öküz İni Mevkii

Giriş kapısı toprak alıında kalmıştır. Ana giriş kapısının ardından tavanı yarım daire şekilli "718x300 cm" ölçülerinde dikdörtgen planlı bir odaya varılmaktadır. Odanın içerisinde az sayıda urne nişi yer almaktadır. Bu odanın içerisinde kırılmış vaziyette bir iç kapı yer almaktadır. Bu kapıdan geçilerek görece küçük bir columbarium mezar odasına varılmaktadır. Bu yapının zemin ölçüleri " $225 \times 198 \mathrm{~cm}$ " dir. Kubbesel formdaki yapı oldukça hasar görmüştür. Yapının tavan yüksekliği $365 \mathrm{~cm}$ 'dir, yerden $250 \mathrm{~cm}$ yukarıda yere paralel $10 \mathrm{~cm}$ kalınlığında bir niş yer almaktadır. Yapının duvarlarında yaklaşık 100 adet ortalama "29x34 cm" ölçülerinde urne nişi bulunmaktadır. Yapının tavanında merkezde olmayan $50 \mathrm{~cm}$ çapında kırık şeklinde baca bulunmaktadır. Bu columbarium mezar diğer örneklere kıyasla küçük ve oldukça yıpranmıştır.

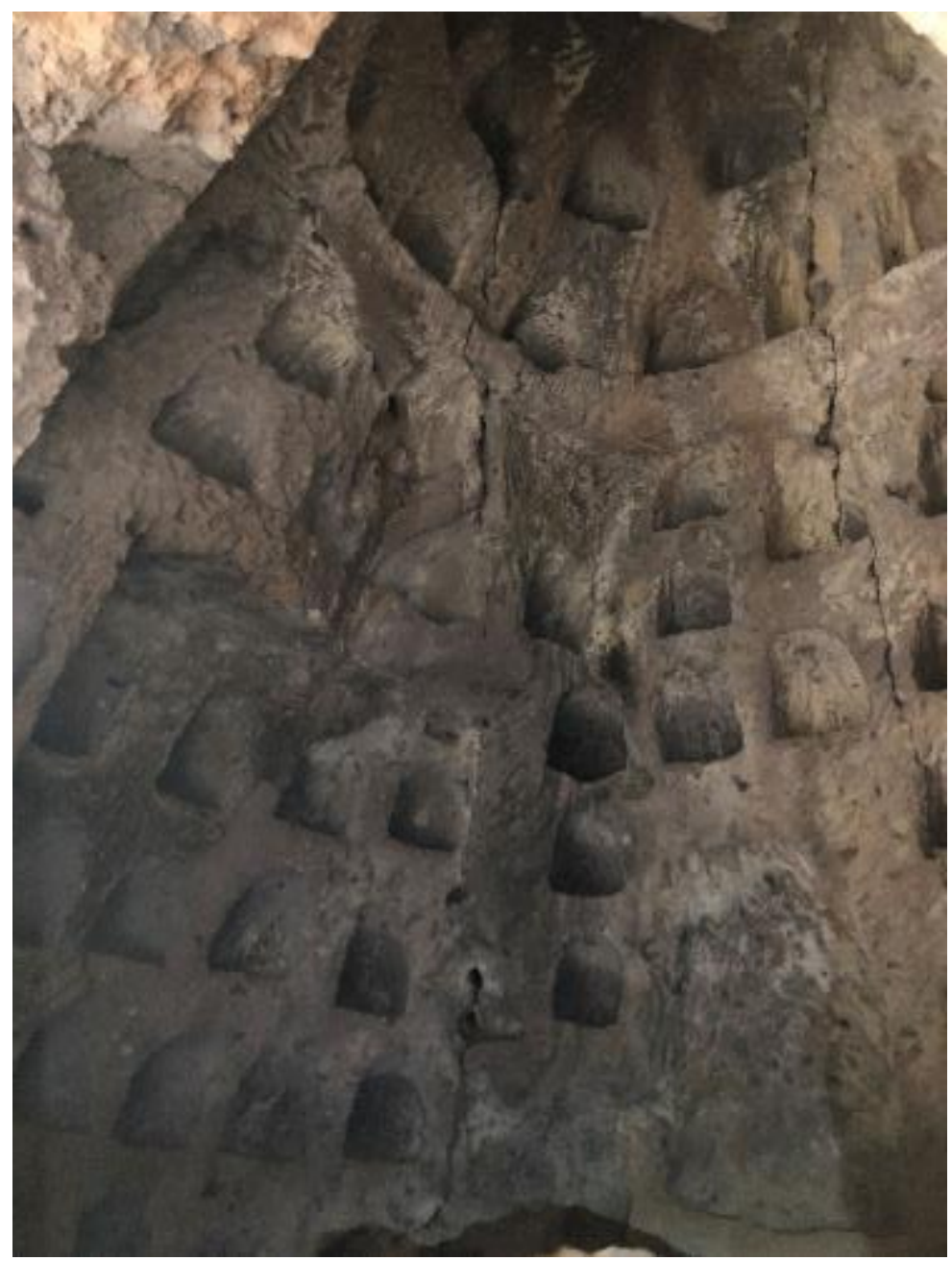

Resim 58: C15 Columbarium Mezarı İçi

Turkish Studies - Historical Analysis

Volume 14 Issue 3, 2019 


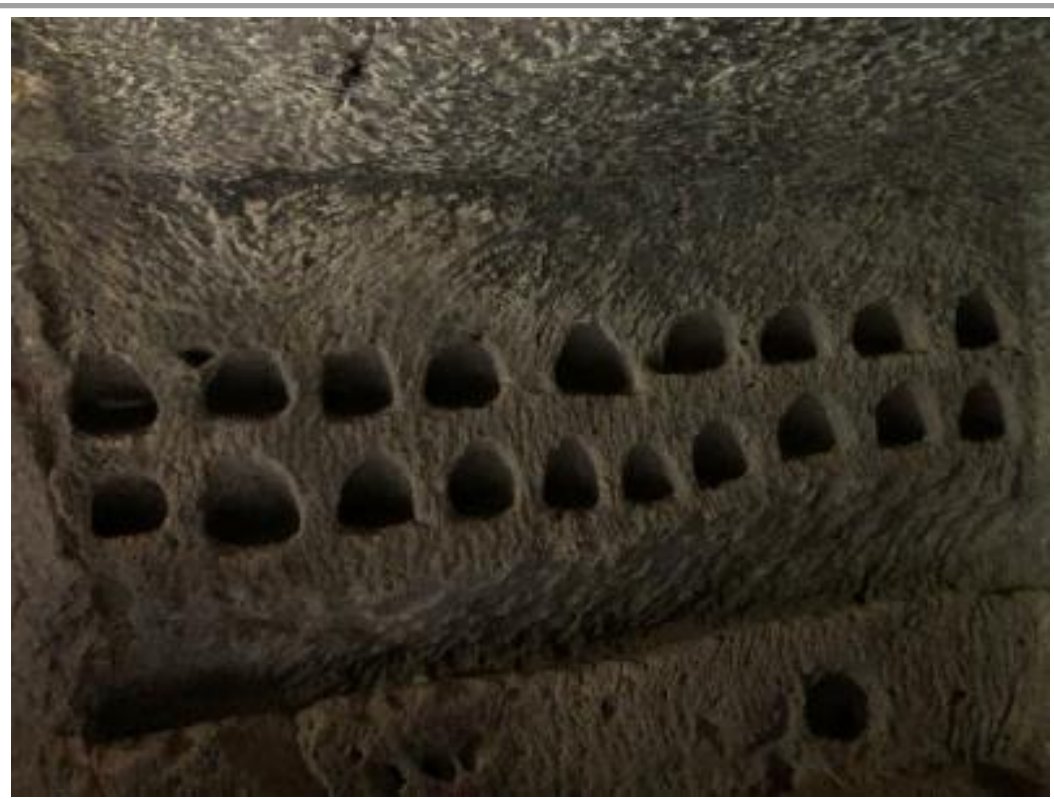

Resim 59: C15 Columbarium Mezarı İçi

\section{Kodu C16}

Konumu Akbin Deresi, Öküz İni Mevkii

Açıklama Girişi oldukça hasar görmüştür ve toprak altındadır. Yapı " $570 x 390 \mathrm{~cm}$ " ölçülerinde oda şeklindedir, tavan yüksekliği ise 255 cm'dir. İçerisinde " $32 \times 35$ cm” ölçülerinde yaklaşık 250 adet urne nişi bulunmaktadır. Girişi kapısından sonra doğrudan columbarium mezar odasına varılmaktadır. Tavanda nişlerle süsleme bulunmaktadır. Mezar nişleri genelde üçgen formunda olup birkaç nişin birleşimi oluşturulmuş yarım daire şeklinde büyükçe nişler de yer almaktadır.

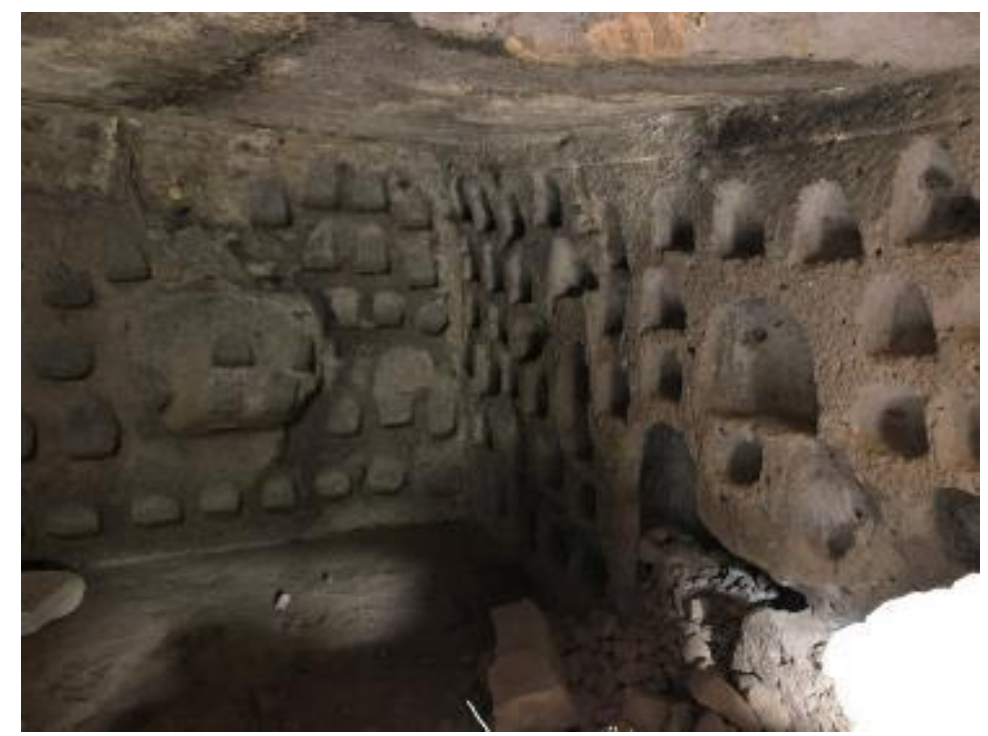

Resim 60: C16 Columbarium Mezarı İçi

Turkish Studies - Historical Analysis

Volume 14 Issue 3, 2019 
Kodu

Konumu

Açıklama

\section{C17}

Akbin Deresi, Öküz İni Mevkii

Girişi oldukça hasar görmüştür ve toprak altındadır. Yapı "484x324 cm" ölçülerinde oda şeklindedir, tavan yüksekliği ise $250 \mathrm{~cm}$ 'dir. İçerisinde " 33 x34 cm" ölçülerinde yaklaşık 250 adet urne nişi bulunmaktadır. Giriși kapısından sonra doğrudan columbarium mezar odasına varılmaktadır. Tavanda nişlerle süsleme bulunmaktadır. Mezar nişleri genelde üçgen formunda olup birkaç nişin birleşimi oluşturulmuş yarım daire şeklinde büyükçe nişler de yer almaktadır. Bu büyük nișlerin içerisine ise daha küçük boyutlu nişlerin kazıldığı da görülmektedir.

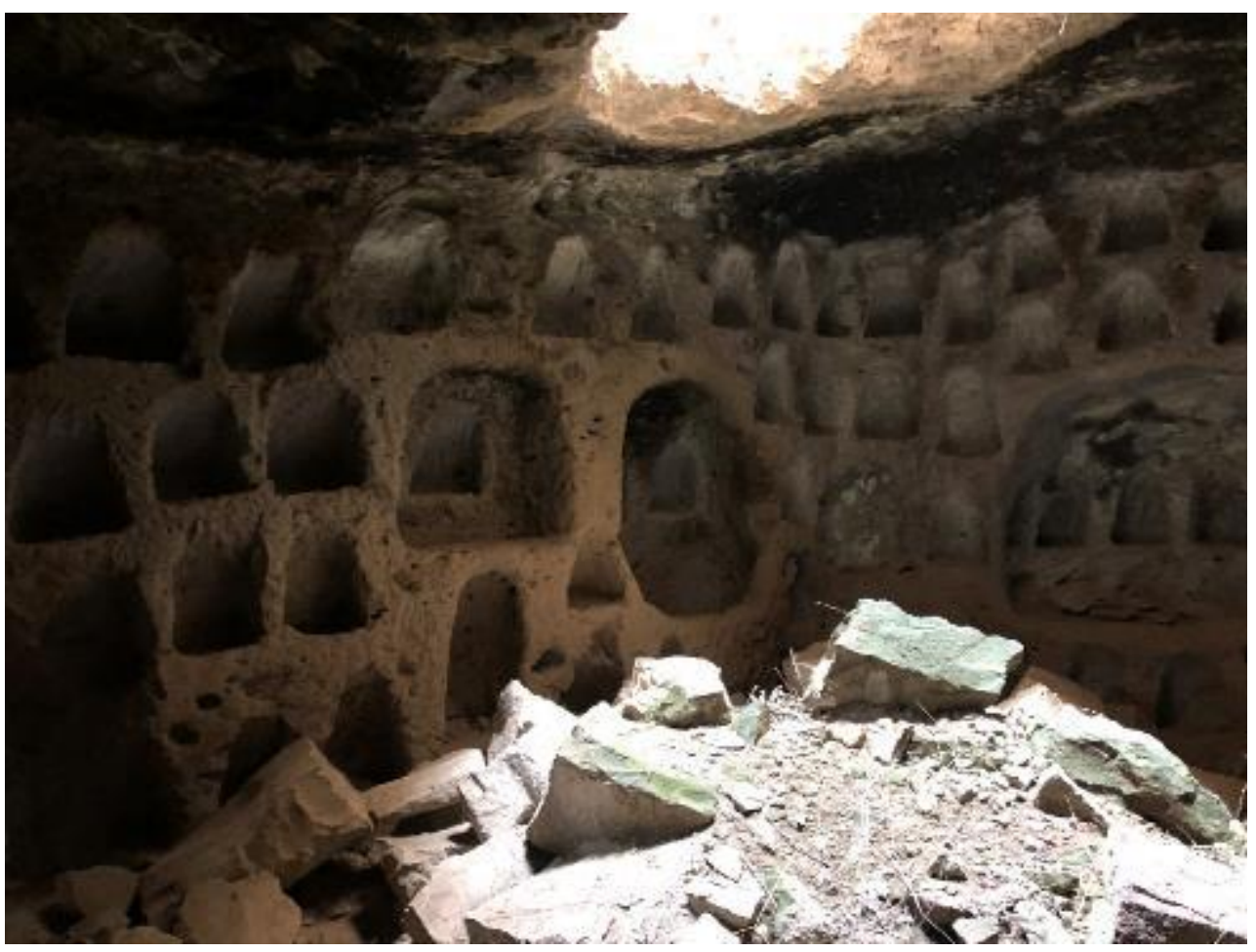

Resim 61: C17 Columbarium Mezarı İçi (Niş İçinde Niş)

Kodu C18

Konumu

Akbin Deresi, Öküz İni Mevkii

Açıklama Tamamen çökmüs ve kayalar ile kapanmış bir girişin arkasında yer alan bu columbarium mezar, emsallerine kıyasla giriş odasındaki mezar nişlerinin çeşitliliği ile farklılaşmaktadır. Giriște yer alan " 362 x793 cm" ölçüsündeki dikdörtgen planlı odanın duvarlarında yaklaşık 100 kadar "30x37 cm" ölçülerinde urne nişi yer almaktadır. Odanın batı duvarında yer alan columbarium mezar giriş kapısının " $95 \times 172 \mathrm{~cm}$ " olduğu görülmektedir. Kapının üst kısmı yarım daire şeklinde yuvarlanmıştır ve oldukça ince işçiliklidir. Columbarium mezarın içerisinde kuzey duvarının yukarı kısmında "90x50 cm" ölçüsünde ilave bir mezar odası yer almaktadır. Bu columbarium mezarda yatay niş üstünde yani kubbeye yakın alanda urne nişi bulunmamaktadır. Columbarium mezarın tavan yüksekliği $440 \mathrm{~cm}$ 'dir ve tavanında bacası bulunmayan $60 \mathrm{~cm}$ çapında bir baca kırığı vardır. Columbarium mezardaki mezar nişleri ise " $30 \times 32 \mathrm{~cm}$ " boyutlarındadır.

Turkish Studies - Historical Analysis

Volume 14 Issue 3, 2019 


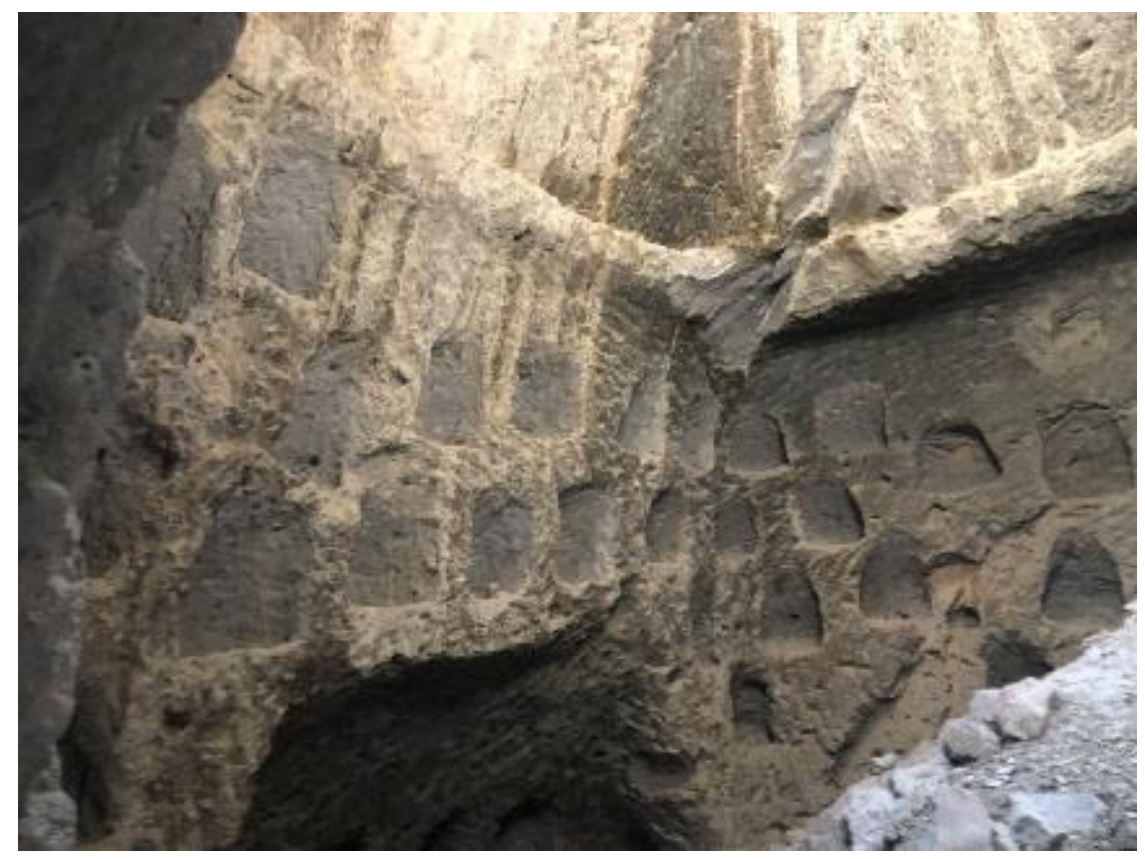

Resim 62: C18 Columbarium Mezarı İçi

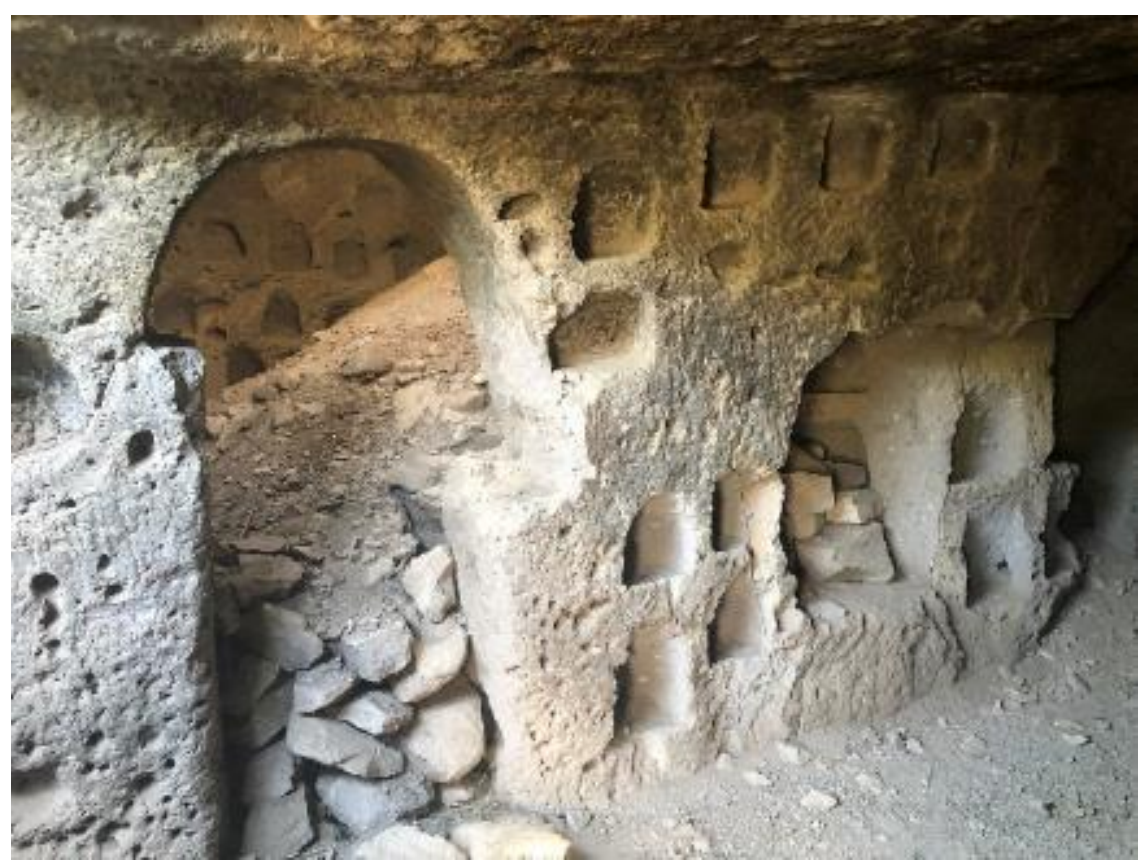

Kodu C19

Konumu Akbin Deresi, Öküz İni Mevkii

Açıklama Yıkılmış bir kapının ardından doğrudan ulaşılan bu columbarium mezarın ön odasının zaman içerisinde yok olduğu tahmin edilebilir. "450x365 cm" taban ölçülerine sahip olan bu columbarium mezarın tavan yüksekliği $566 \mathrm{~cm}$ 'dir. Yerden tavana doğru ilerlerken " 244 x492 cm" de birer tane $10 \mathrm{~cm}$ genişlikli yatay doğru şeklinde niş bulunmaktadır.

Turkish Studies - Historical Analysis

Volume 14 Issue 3, 2019 
Columbarium mezarın tavanında $50 \mathrm{~cm}$ genişliğinde kırık bir baca çıkışı vardır. Yapıda 150 civarında urne nişi bulunmakta olup bunların " $25 \times 27 \mathrm{~cm}$ ” ölçüsünde olduğu görülmektedir. Yapının doğusunda iki tane iç mezar odası yer almaktadır, yine yapının güneyinde tavanı ince işçilikli nişlerle bezeli bir oda daha bulunmaktadır. $\mathrm{Bu}$ columbarium mezarın tavanında emsallerinden farklı olarak karşılıklı 4 adet " $60 \mathrm{x} 80 \mathrm{~cm}$ " ölçülerinde yarım daire şeklinde süsleme amaçlı yapılmış ince işçilikli derin olmayan niş yer almaktadır. Columbarium mezara güneyden girilen kapı son derece ince işçilikli ve estetik açıdan değerlidir.

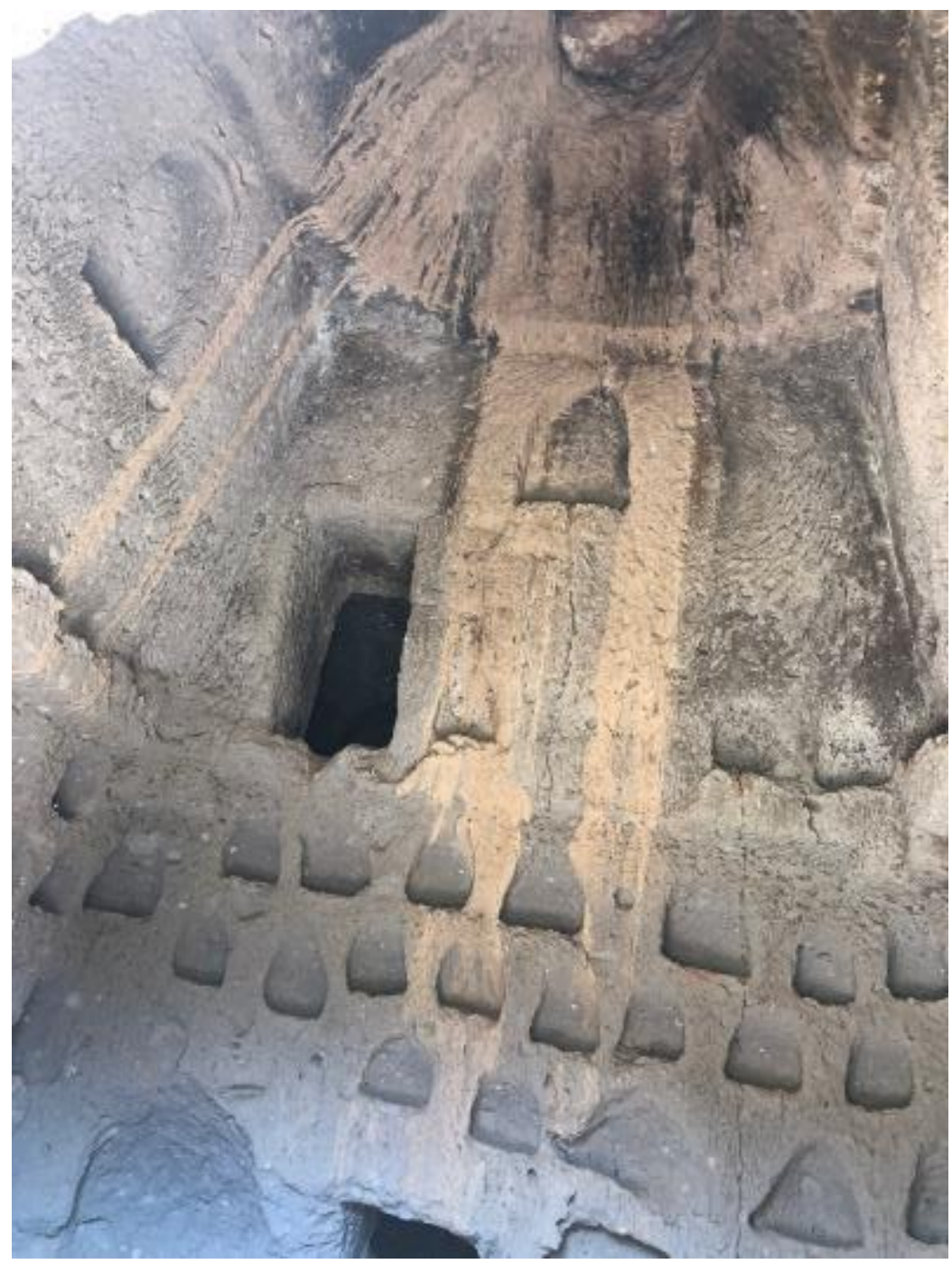

Kodu

Konumu

Açıklama

\section{C20}

Resim 64: C19 Columbarium Mezarı İçi

Akbin Deresi, Öküz İni Mevkii

Tamamen yok olmuş bir girişin kuzeyinde yer alan bu kubbe tipli columbarium mezar oldukça yıpranmıştır. Columbarium mezarın zemin ölçüleri "291x266 cm" olup aslında oldukça küçük bir columbarium mezardır. İçerisinde " $30 \times 32$ cm" ölçülerinde yaklaşık 150 adet urne nişi yer almaktadır. Yapının tavan yüksekliği $542 \mathrm{~cm}$ olup girişinin bir kısmı 
tamamen yıkılmıştır. Bu columbarium mezarın doğu tarafında oval bir giriş ile ulaşılan ikinci bir oda daha bulunmaktadır. Bu odanın tavanları ince işçilikli nişlere sahiptir ve duvarlarında mezar nişleri yer almaktadır.

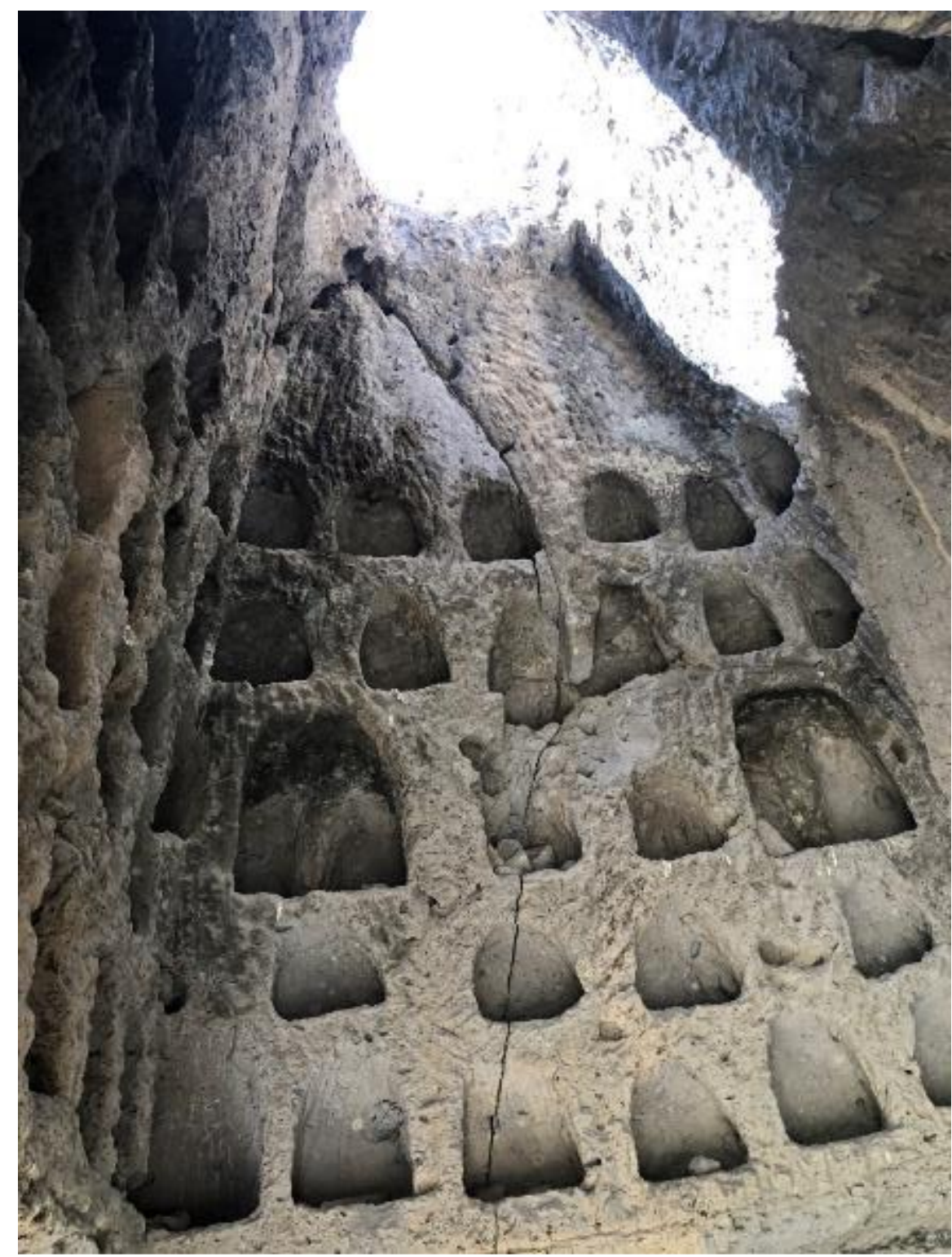

Kodu

C21

Resim 65: C20 Columbarium Mezarı İçi

Konumu

Akbin Deresi, Öküz İni Mevkii

Açıklama Oda tipli ve iki katlı bu yapının içerisinde 200 civarında urne nişi yer almaktadır. Ayrıca bu yapının ana odasının ve yan odalarının içerisinde toplamda 11 adet yer altı depo bulunmaktadır. $50 \mathrm{~cm}$ çapında bir baca kırı̆̆ı $445 \mathrm{~cm}$ yükseliğindeki tavanında yer almaktadır. Yapının içerisinde ikinci kat olarak adlandırılan alan aslında asma bir kattır ve buranın batısında bir oda daha bulunmaktadır. "85x207 cm" ölçüsünde bir ana giriş kapısı bulunan bu yapının ana giriş odası " $342 \times 560 \mathrm{~cm}$ " ölçülerindedir. 


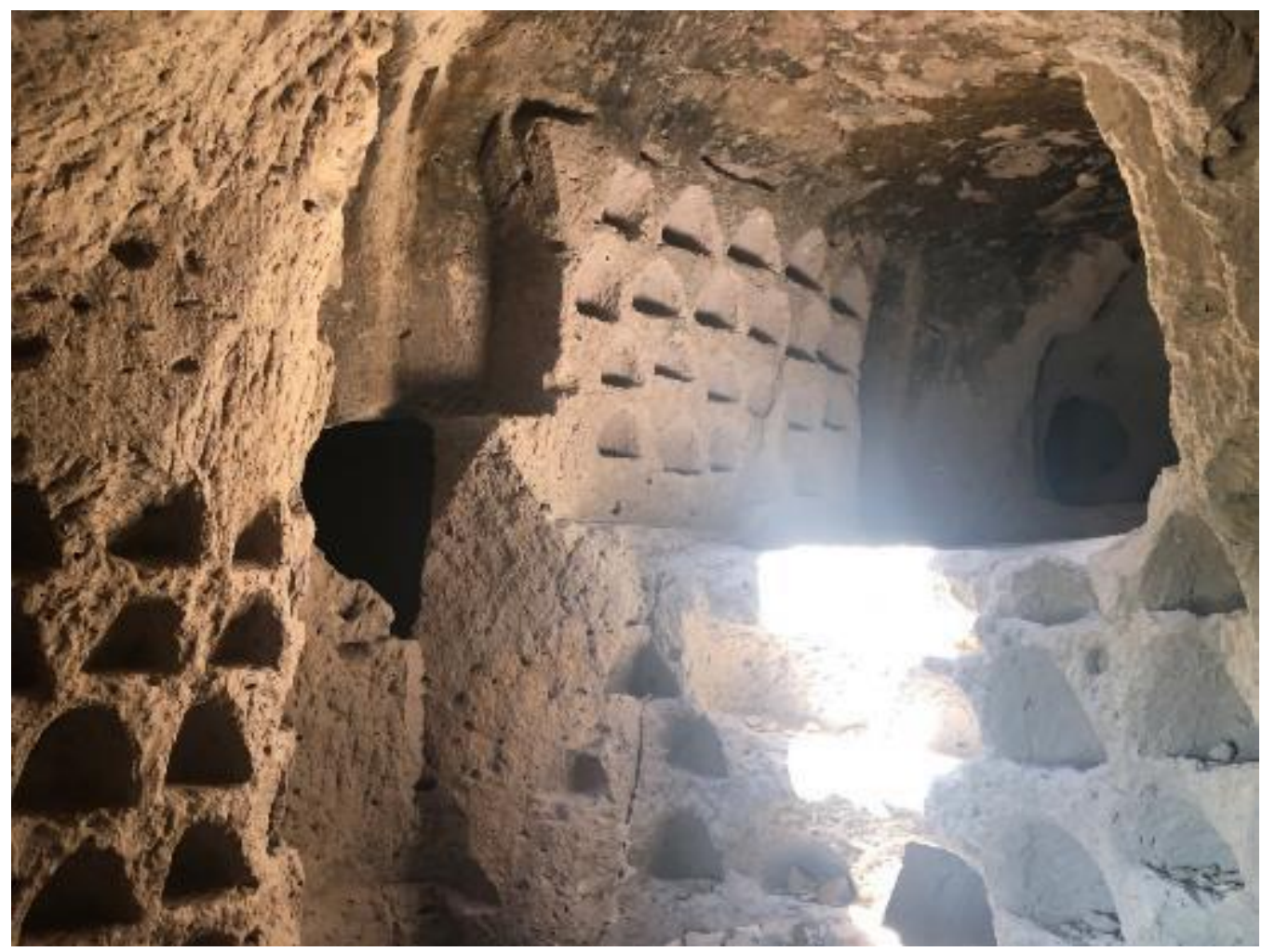

Resim 66: C21 Columbarium Mezarı İçi

Kodu

Ek 4. Koramaz Vadisi Güvercinlikleri

Konumu

Açıklama

D1

Vekse, Güvercinlik Havzası

Bu havzada 15 civarında güvercinlik yer almaktadır. Tamamının ortak özelliği genel anlamda "40x70 cm" ölçüsünde dar bir zemin kapısına sahip olmaları, içerisindeki kaya oyma işçiliğinin özensiz olmasıdır.

Bu yapıya " $40 \times 75$ cm" ölçüsüne sahip dar bir kapıdan sürünerek girilmektedir. Yapı elips formunda özensiz bir işçilikle oyulmuştur. " $673 \times 459 \mathrm{~cm}$ ” ölçülerine sahiptir. Yapının baca giriş çapı yaklaşı $83 \mathrm{~cm}$ 'dir. Baca deliğinin yüzey noktasında taşla örme bir baca bulunmaktadır. İçerisinde 50 kadar tünek bulunmaktadır ve tünekler " $43 \times 40 \mathrm{~cm}$ " ölçüsündedir. Tavan yüksekliği ise $227 \mathrm{~cm}$ 'dir. Yapı içerisinde süsleme amaçlı niş gibi ince işçilik bulunmamaktadır. 


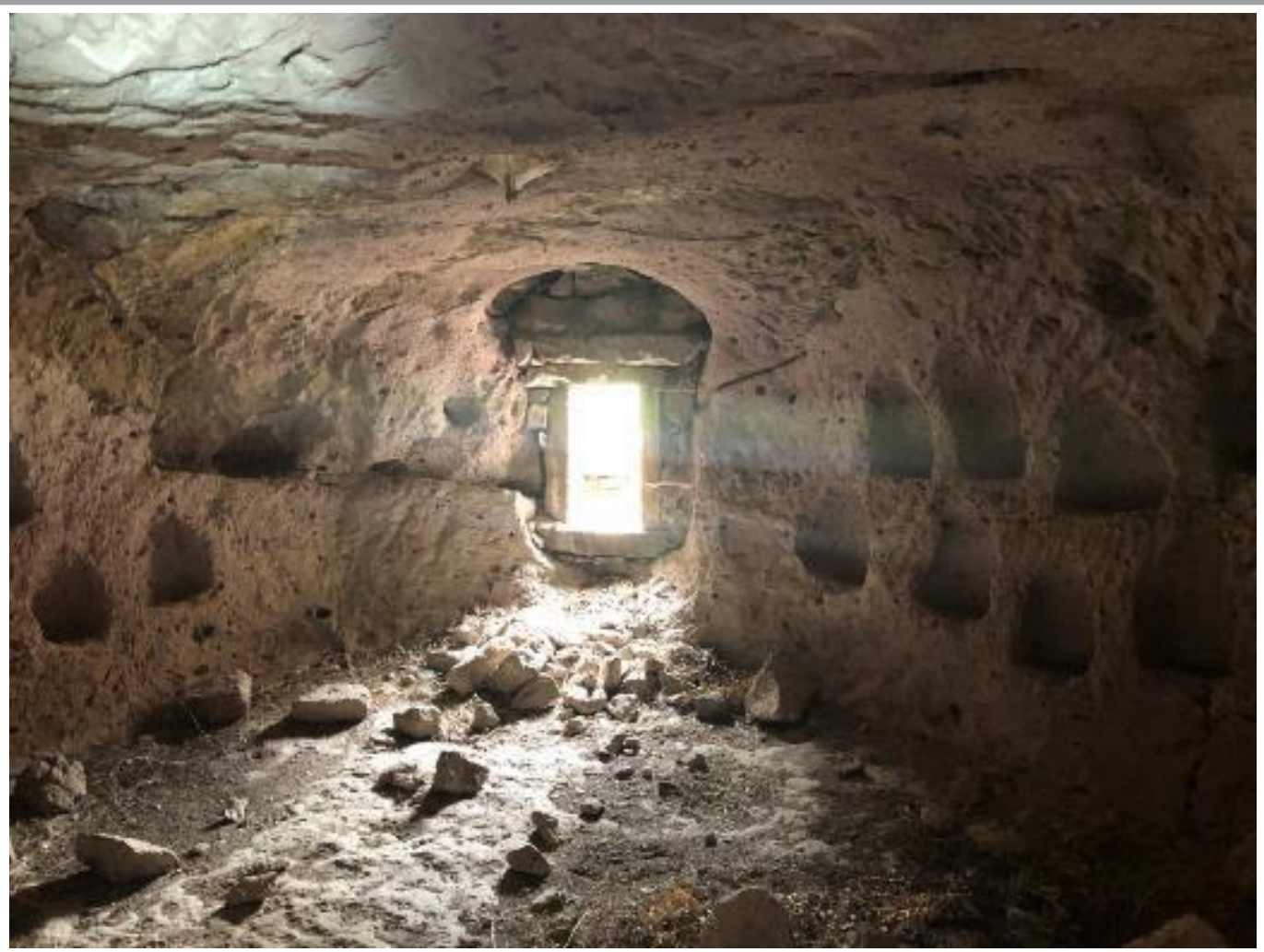

Kodu D2

Resim 67: D1 Güvercinlik İçi

Konumu Vekse, Güvercinlik Havzas1

Açıklama Bu yapıya " $45 \times 70 \mathrm{~cm}$ " ölçüsüne sahip dar bir kapıdan sürünerek girilmektedir. Yapı elips formunda özensiz bir işçilikle oyulmuştur. "392x544 cm" ölçülerine sahiptir. Yapının baca giriş çapı yaklaşı $80 \mathrm{~cm}$ 'dir. Baca deliğinin yüzey noktasında taşla örme bir baca bulunmaktadır. İçerisinde 50 kadar tünek bulunmaktadır ve tünekler " 41 x33 cm" ölçüsündedir. Tavan yüksekliği ise $227 \mathrm{~cm}$ 'dir. Yapı içerisinde süsleme amaçlı niş gibi ince işçilik bulunmamaktadır. 


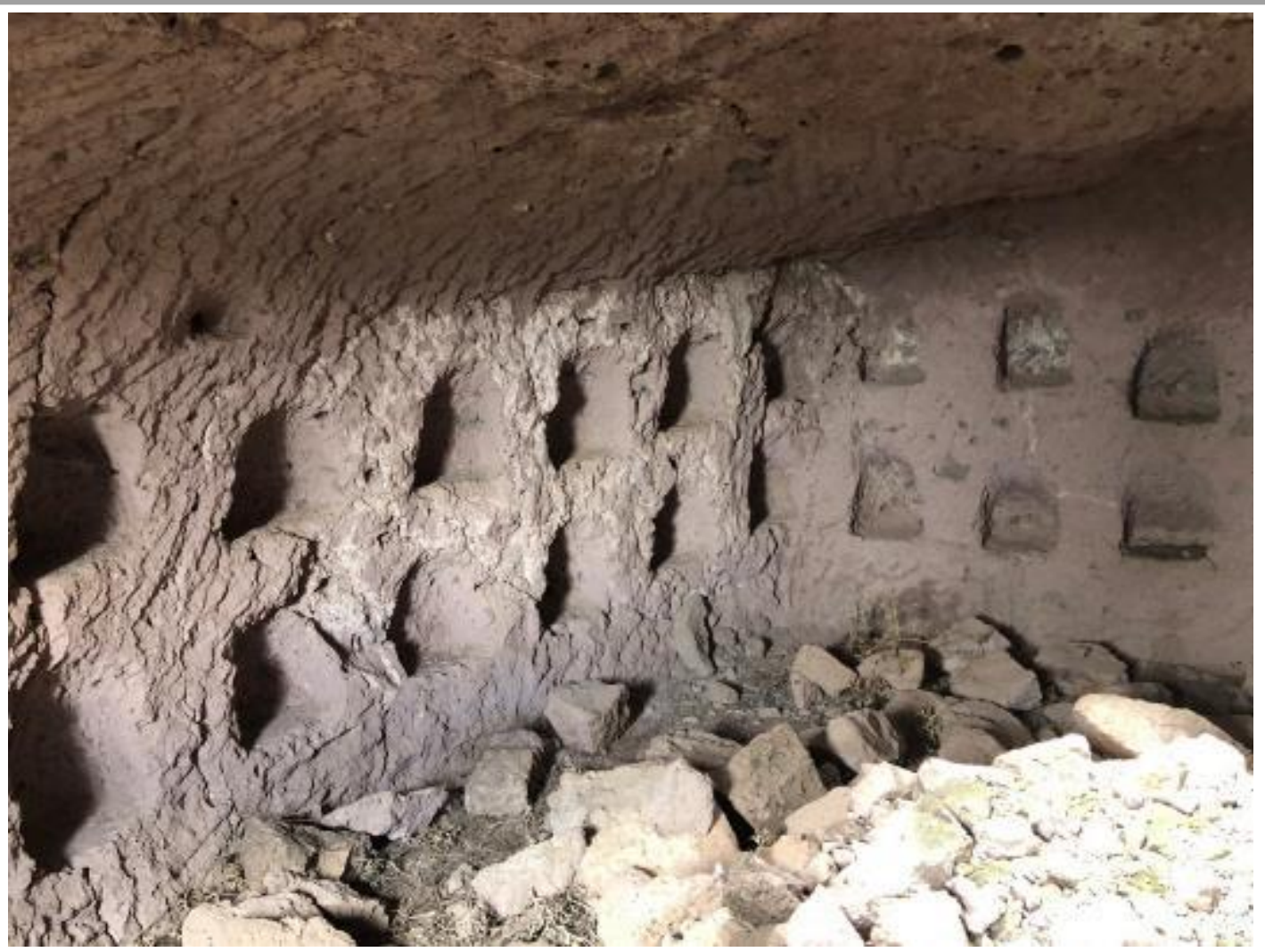

Kodu

D3

Resim 68: D2 Güvercinlik İçi

Konumu

Küçük Bürüngüz, Tümülüs Altı

Açıklama

$\mathrm{Bu}$ yapının kapısı tamamen çökmüş durumdadır, ancak komşu yapılara bakılınca dar ve zeminden bir kapıdan girildiği anlaşılmaktadır. Yapı elips formunda özensiz bir işçilikle oyulmuştur. " $529 \times 486 \mathrm{~cm}$ ” ölçülerine sahiptir. Yapının baca giriş çapı yaklaşık $83 \mathrm{~cm}$ 'dir. Baca deliğinin yüzey noktasında taşla örme bir baca bulunmaktadır. İçerisinde 50 kadar tünek bulunmaktadır ve tünekler " $28 \times 21 \mathrm{~cm}$ " ölçüsündedir. Tavan yüksekliği ise 205 cm'dir. Yapı içerisinde estetik amaçlı ince işçilikli nişler bulunmamaktadır. 


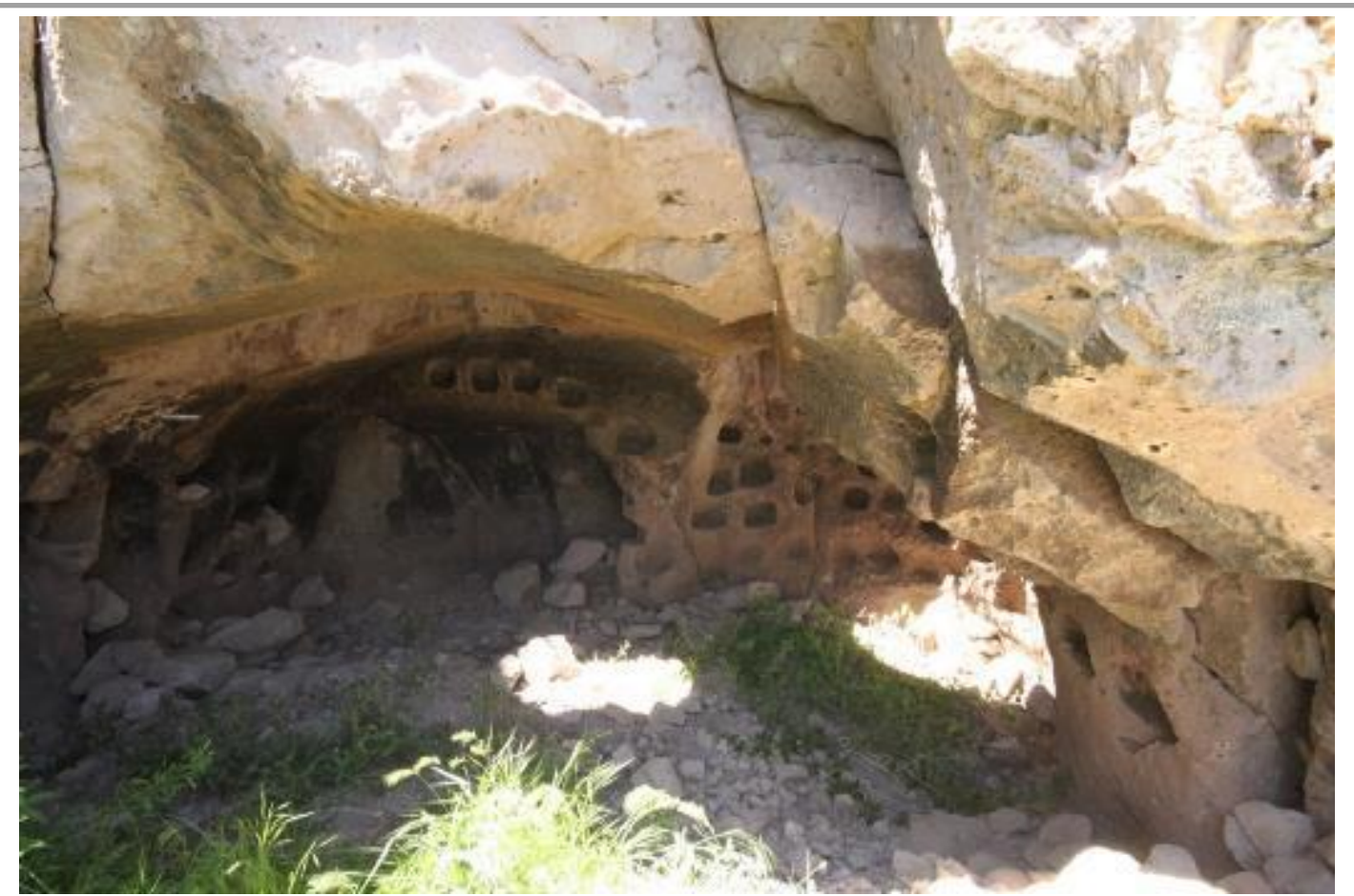

Resim 69: D3 Güvercinlik İçi

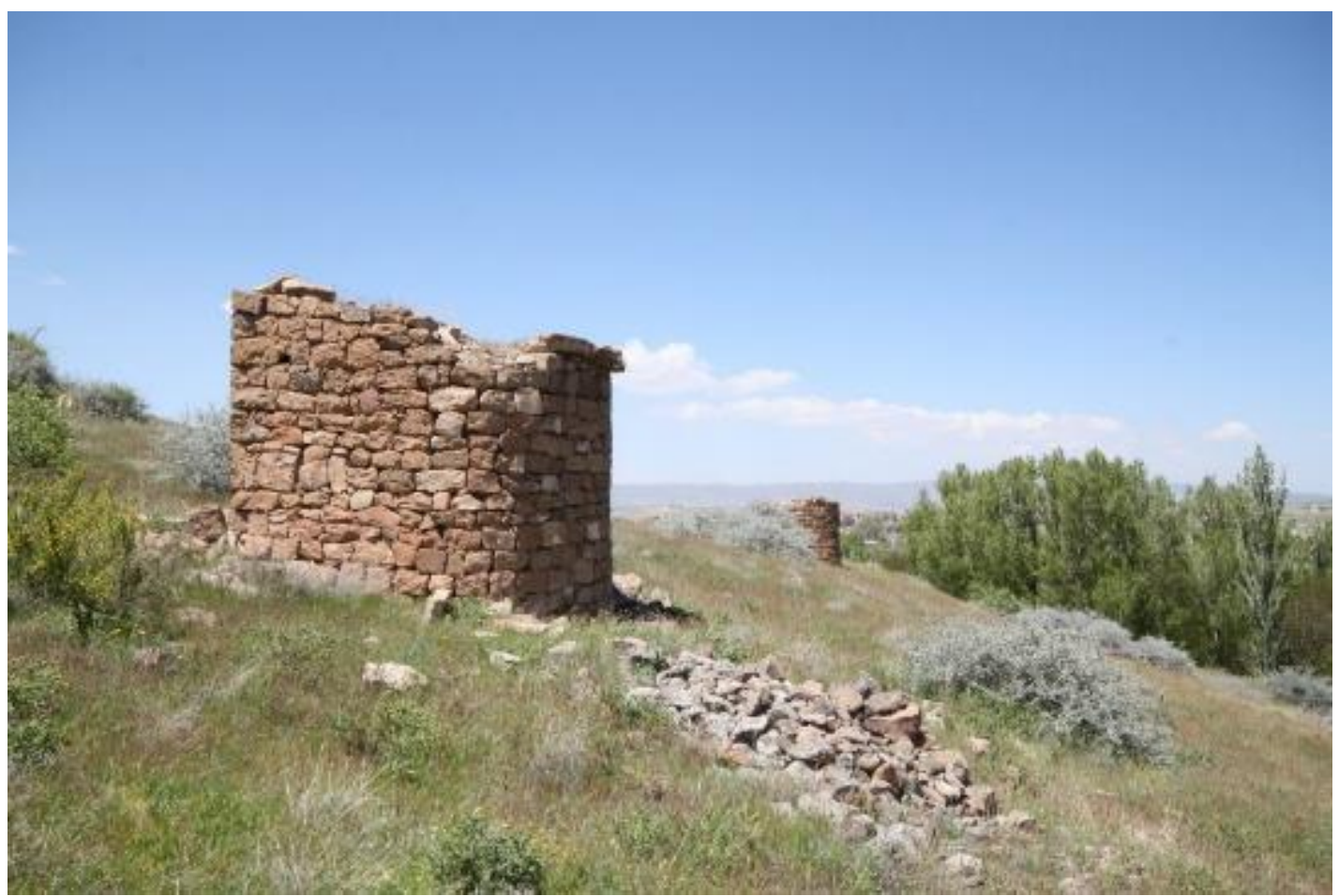

Resim 70: D3 Güvercinlik Bacası 


\section{Teşekkürler}

$\mathrm{Bu}$ çalışmayı gerçekleştirirken her an yanımda olan, motive eden, metinleri okuyan, görselleri inceleyen ve yol gösteren Prof. Dr. Osman ÖZSOY'a, çalışma süresince çektiğim fotoğrafları ve öne sürdüğüm tezleri inceleyerek görüş bildiren Dorian Borbonus'a, çalışmanın esin kaynağı olan Prof. Dr. Eric Gilli’ye, haritalama, ölçüm ve analiz konularında yol gösteren Ali Yamaç'a, bazı fotoğraflarını kullandığım Reiner Straub'a, Koramaz Vadisi kitabı yazarı ve bu çalışmanın yol göstericisi Hüseyin Cömert'e, yerel rehberler Ahmet Bektaş, Hacı Kaya ve Mehmet Bilim'e, ölçümlerde destek veren Harun Karakoç'a, çizimlerde ilham veren Tamara Tanbay'a ve en önemlisi onlara ayırmam gereken zamanı esirgeyerek bu çalışmaya aktarmama müsaade eden başta eşim Egemen Yazlık olmak üzere tüm aileme teşekkür ederim.

\section{KAYNAKÇA}

Akkurnaz, F. (2016). Eski Yunan Kapları ve İşlevleri, Yayınlanmış Yüksek Lisans Tezi, Adnan Menderes Üniversitesi.

Borbonus, D. (2014). Columbarium Tombs and Collective Identity in Augustan Rome. Cambridge University Press.

Büyükmıhçı, G. (2006). “19. Yüzyıl Anadolu’sundan Günümüze Yansıyan Özgün Bir Tarımsal Ticaret Yapıs1: Güvercinlikler”. Erciyes Üniversitesi Sosyal Bilimler Enstitü Dergisi. Sayı: 2006/2. 97119.

Civelek, A. (2007). "Roma Cenaze Törenleri ve Gömme Gelenekleri”. Arkeoloji ve Sanat Dergisi, Sayı: 124. $71-80$.

Cömert, H. (2008). Koramaz Vadisi. Ağırnas Belediyesi Yayını.

Demirel, E. (2014). Kayseri Yürüyüş Rotaları ve Turizm Keşif Rehberi. Kayseri Valiliği Yayını.

Erkiletlioğlu, H. (1993). Kayseri Tarihi. Kayseri Valiliği İl Kültür Müdürlüğü.

Erkiletlioğlu, H. (2018). “Kayseri'de Sürgün Bir Roma İmparatoru”. Kayseri Şehir Dergisi. 04/2018. 27-31.

Gilli, E. (2017). "From Columbaria to Dovecotes: Two Thousand Years of Use of Cave Dwellings in Ağırnas (Kayseri, Turkey)”. Proceedings Of International Congress Of Speleology In Artificial Cavities - Cappadocia. Hypogea 2017. 446-453

Hild, F. (1977). Das Byzantinische Strassensystem In Kappadokien. Verlag Der Österreichischen Akademi Der Wissenschaften.

Honigmann, E. (1935). Die Ostgrenze Des Byzantinischen Reiches. De L'Institut Oriental.

Hülagü, M. (2001). “Osmanlı Devleti'nde Güherçile Üretimi Ve Kayseri Güherçile Fabrikası”. Sosyal Bilimler Enstitüsü Dergisi. Say1: 11, 73-93.

Karakaya, N. (2013). Kayseri Ansiklopedisi. Cilt III. Kayseri Büyükşsehir Belediyesi Kültür Yayınları.

Karakaya, N. (2014). "Kayseri'nin Gesi Beldesi, Küçük Bürüngüz (Subaşı) Köyü ile Ağırnas Vadisi'ndeki Bizans Dönemine Ait Sivil-Zirai Kaya Yapıları". Turkish Studies - International Periodical For The Languages, Literature and History of Turkish or Turkic. Sayı: 9/10. 335358.

Kulakoğlu, F. (2010). Anadolu’nun Önsözü Kültepe Kaniş-Karumu. Kayseri Büyükşehir Belediyesi. 
Moravcsik ve Jenkins. (1967). Constantine Porphyrogenitus De Administrando Imperio. Center for Byzantine Studies Harvard University.

Osmanlı Devlet Arşivi, devletarsivleri.gov.tr, Hicri 14.10.1018 (Görülme Tarihi: 15/08/2019).

Owen, T. (1806). Geoponica, Agricultural Pursuits. Playhouse-Yard, Blackfriars.

Özbek, Y. ve Arslan, C.(2008). Kayseri Taşınmaz Kültür Varlıkları Envanteri. Cilt I. Kayseri Büyükşehir Belediyesi Yayını.

Strabon. (2012). Geographika, Arkeoloji ve Sanat Yayınları.

Straub, R. Yamaç, A. ve Yazlık, B. (2019). "Die Untergrund-Christen - Isbidin Kaya Kilisesi, eine stark gefahrdete Hohlenkirche in Kappadokien”. Mitteilungen des Verbandes der Deutschen Höhlenund Karstforscher e.V. 65(1+2):25-29.

Yiğitpaşa, D., "Urartu Ölü Gömme Gelenekleri ve Ölümle İlgili Ritüeller”, Atatürk Üniversitesi, Güzel Sanatlar Enstitüsü Dergisi, XXV, 2010, 177-202.

Yiğitpaşa, D., "Van/Altıntepe Urartu Nekropolü Sunu Kapları”, Atatürk Üniversitesi, Güzel Sanatlar Enstitüsü Dergisi, XXVI, 2011, 111-153.

Zgusta, L. (1984). Kleinasiatische Ortsnamen. Carl Winter - Universitatsverlag.

Kayseri Yer Altı Yapıları Envanteri, İkinci Ara Rapor (2015). Kayseri Büyükşehir Belediyesi Yayını. 